\title{
Estudos de literatura e imprensa
}

\author{
Alvaro Santos Simões Junior
}

SIMÕES JUNIOR, AS. Estudos de literatura e imprensa [online]. São Paulo: Editora UNESP; São Paulo: Cultura Acadêmica, 2014, 195 p. ISBN 978-85-68334-47-8. Available from SciELO Books $<\underline{\text { http://books.scielo.org }>\text {. }}$

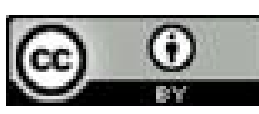

All the contents of this work, except where otherwise noted, is licensed under a Creative Commons Attribution 4.0 International license.

Todo o conteúdo deste trabalho, exceto quando houver ressalva, é publicado sob a licença Creative Commons Atribição 4.0.

Todo el contenido de esta obra, excepto donde se indique lo contrario, está bajo licencia de la licencia Creative Commons Reconocimento 4.0. 


\section{Estudos \\ DE LITERATURA E IMPRENSA}




\title{
FUNDAÇÃO EDITORA DA UNESP
}

\author{
Presidente do Conselho Curador \\ Mário Sérgio Vasconcelos \\ Diretor-Presidente \\ José Castilho Marques Neto \\ Editor-Executivo \\ Jézio Hernani Bomfim Gutierre
}

Superintendente Administrativo e Financeiro

William de Souza Agostinho

Assessores Editoriais

João Luís Ceccantini

Maria Candida Soares Del Masso

Conselho Editorial Acadêmico

Áureo Busetto

Carlos Magno Castelo Branco Fortaleza

Elisabete Maniglia

Henrique Nunes de Oliveira

João Francisco Galera Monico

José Leonardo do Nascimento

Lourenço Chacon Jurado Filho

Maria de Lourdes Ortiz Gandini Baldan

Paula da Cruz Landim

Rogério Rosenfeld

Editores-Assistentes

Anderson Nobara

Jorge Pereira Filho

Leandro Rodrigues 
ALVARO SANTOS SIMÕES JUNIOR

\section{EsTUdos}

\section{DE LITERATURA E IMPRENSA}


Direitos de publicação reservados à:

Fundação Editora da Unesp (FEU)

Praça da Sé, 108

01001-900 - São Paulo - SP

Tel.: (0xx11) 3242-7171

Fax: (0xx11) 3242-7172

www.editoraunesp.com.br

www.livrariaunesp.com.br

feu@editora.unesp.br

CIP - BRASIL. Catalogação na publicação

Sindicato Nacional dos Editores de Livros, RJ

S612e

Simões Junior, Alvaro Santos

Estudos de literatura e imprensa / Alvaro Santos Simões Junior. São

Paulo: Editora Unesp Digital, 2014.

Recurso digital

Formato: ePDF

Requisitos do sistema: Adobe Acrobat Reader

Modo de acesso: World Wide Web

ISBN 978-85-68334-47-8 (recurso eletrônico)

1. Linguística. 2. Linguagem e línguas. 3. Linguística histórica. 4. Livros eletrônicos. I. Título.

$15-20353$

CDD: 410

CDU: $81 ' 1$

Este livro é publicado pelo projeto Edição de Textos de Docentes e

Pós-Graduados da UNESP - Pró-Reitoria de Pós-Graduação da UNESP (PROPG) / Fundação Editora da Unesp (FEU)

Editora afiliada:

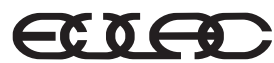

Asociación de Editoriales Universitarias de América Latina y el Caribe

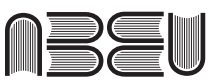

Associação Brasileira de Editoras Universitárias 
Aos meus amores,

Fatima e Ligia 


\section{SUMÁRIO}

\section{Apresentação 9}

1 A (re)definição do trabalho intelectual no início do século XX 13

2 Localismo e cosmopolitismo nas revistas de ano 23

3 Entre Zola e Eça: o Naturalismo brasileiro em seu apogeu (1888) 35

4 A repercussão da morte de Zola em periódicos brasileiros 51

5 Literatura paradidática e nacionalismo na Primeira República 67

6 Retratos e poemas de O Álbum (1893-1895) de Artur Azevedo 91

7 As resenhas de livros simbolistas no vespertino A Notícia (1897-1905) 113

8 O jovem Paulo Barreto e os simbolistas 133

9 Os eróticos diários de Ana Cristina Cesar 149

10 Menalton Braff para jovens 169

Referências bibliográficas 185 


\section{Apresentação}

Reúnem-se neste volume ensaios escritos em circunstâncias muito distintas, mas que são o resultado de um interesse constante pela produção, circulação e recepção de obras literárias no Brasil. Os dois primeiros originaram-se de palestras proferidas em 2005 e 2006 na Faculdade de Ciências e Letras de Assis (Unesp) por gentil convite de Patricia Peterle e Andrea Santurbano, que lá promoviam os colóquios internacionais do Centro Ítalo-Luso-Brasileiro de Estudos Linguísticos e Culturais (Cilbelc). No primeiro texto, evidencia-se o estabelecimento de novas condições para o trabalho intelectual no início do século XX. Com o segundo, estuda-se uma modalidade bem-sucedida de atuação profissional dos escritores que, no entanto, era combatida pela crítica e, até certo ponto, menosprezada por eles próprios.

Embora resultassem de pesquisas anteriores e de experiência em sala de aula, o terceiro ensaio (que trata de romances naturalistas brasileiros) e o quarto (que analisa necrológios e notícias a respeito da morte de Émile Zola) foram ambos adrede escritos para eventos que privilegiavam a obra do romancista francês: o XIII ${ }^{e}$ Colloque International de l'Aizen (Association Internationale Zola et le Naturalisme), realizado no Rio de Janeiro em 2004, e Visages de la Provence: Zola, Cézanne etc., ocorrido em Aix-en-Provence 
no ano de 2007. Em ambos, pode-se vislumbrar a complexa relação dos intelectuais brasileiros com os amados e, eventualmente, odiados mestres europeus.

O texto a respeito da literatura paradidática da Primeira $\mathrm{Re}$ pública, à qual se dedicaram sistematicamente vários escritores daquele período, articula-se com antigo interesse deste pesquisador pelos manuais escolares de Olavo Bilac, mas se produziu no bojo de um projeto de pesquisa coordenado pela Università degli Studi Roma Tre com a participação da Unesp e da Universidad de Salamanca.

Os três ensaios seguintes resultaram de uma ambiciosa investigação ainda em curso sobre a repercussão do Simbolismo nos periódicos brasileiros e revelam a importância da imprensa periódica para a divulgação e circulação das obras literárias. No primeiro deles, analisa-se um hebdomadário dirigido de 1893 a 1895 por Artur Azevedo, que, em seu tempo, desempenhou papel fundamental na vida literária brasileira, estimulando e divulgando, com sua atividade jornalística, o trabalho de jovens escritores. $\mathrm{O}$ segundo examina a atuação de Medeiros e Albuquerque como crítico literário do vespertino A Notícia de 1897 a 1905, ao passo que o terceiro procura abordar as intervenções do jovem Paulo Barreto, redator da Cidade do Rio, jornal de José do Patrocínio, contra o Simbolismo brasileiro na virada do século.

O penúltimo estudo, dedicado à poesia de Ana Cristina Cesar, foi em sua origem um modesto trabalho de conclusão de uma disciplina de Pós-Graduação ministrada em 1996 pela professora Maria Lúcia de Barros Camargo (UFSC) na Faculdade de Ciências e Letras de Assis. Deixando-se de lado a ingenuidade do jovem autor, agravada por certa autossuficiência, pode-se, com o texto, refletir sobre a obra da autora mais representativa da "geração mimeógrafo”, que criou, para uso próprio, em pleno regime militar, um circuito independente de produção e circulação de obras literárias, em desafio à hegemonia das grandes casas editoras.

Encerrando o volume, encontra-se um ensaio sobre a obra de Menalton Braff direcionada ao público jovem. Atestando a matu- 
ridade da atividade editorial brasileira, esse autor contemporâneo dedica-se profissionalmente à literatura, dirigindo sua produção para uma fatia específica do público leitor.

Cabe, por fim, agradecer a Capes, Fundunesp, CNPq e Fapesp o apoio concedido ao autor sob diferentes formas.

Assis, janeiro de 2015 


\section{1 \\ A (RE)DEFINIÇÃO DO TRABALHO INTELECTUAL NO INÍCIO DO SÉCULO $\mathbf{X X}^{1}$}

Pretende-se aqui definir de modo muito sumário modificações fundamentais por que passou a condição de escritor na virada do século XIX para o século XX.

Na década de 1870, quando o movimento republicano ganhou força, os escritores brasileiros não podiam sequer sonhar em dedicar-se integralmente à criação literária. Para viver era necessário seguir outras profissões como a docência, a magistratura, a advocacia ou a medicina e reservar apenas o tempo livre para dedicar-se às musas. ${ }^{2} \mathrm{D}$. Pedro II, que se considerava um intelectual e alimentava veleidades poéticas, apreciava desempenhar o papel de mecenas, o que de fato às vezes fazia. Entretanto, a maioria dos jovens escritores (que eram republicanos e anticlericais) não poderia jamais aceitar a proteção imperial.

Em 1876, Aluísio Azevedo (1857-1913) deixou São Luís do Maranhão e foi ao Rio de Janeiro com a ambição de estudar de-

1 Dedica-se este ensaio a Carlos Baumgarten e Mauro Póvoas.

2 V. Broca (1957, p.104). Há duas formas de sobrevivência para o escritor: 1) com financiamento interno mediante venda de direitos autorais; 2) com financiamento externo via mecenato ou autofinanciamento. $\mathrm{O}$ segundo emprego, que é na verdade o primeiro, configura uma situação de autofinanciamento (cf. Escarpit, 1964, p.47-9). 
senho e pintura. Na então Corte Imperial, frequentou a Escola de Belas Artes, pintou alguns retratos e trabalhou como caricaturista de algumas revistas ilustradas (O Fígaro, O Mequetrefe e A Comédia Popular, entre outras). No entanto, o jovem maranhense logo se integrou a um grupo de intelectuais liderado por José do Patrocínio (1853-1905), que iniciaria a campanha abolicionista na Gazeta de Notícias em 1877. Esse grupo de entusiasmados republicanos e abolicionistas, a que pertenceram Artur Azevedo (1855-1908), Teófilo Dias (1857-1889), Artur Barreiros (1856-1885), Fontoura Xavier (1856-1922), Valentim Magalhães (1859-1903) e Artur de Oliveira (1851-1882), logo voltaria seu ímpeto revolucionário contra os padrões literários vigentes. As Farpas (iniciadas em 1871), de Ramalho Ortigão e Eça de Queiroz, tornaram-se modelo de verve polêmica e combatividade política. Já O primo Basílio (1878), cuja repercussão foi intensa e escandalosa, apontava novos caminhos para o romance de observação e crítica social. Para a renovação da poesia deu grande contribuição Artur de Oliveira, que vivera na Europa por dois anos (1871-1872) e alegava haver convivido com poetas como Leconte de Lisle e Théophile Gautier. Com os amigos à sua volta, sentava-se às mesas de café e lia poemas dos parnasianos franceses e de Charles Baudelaire (v. Broca, 1991, p.55-7).

Como bem demonstrou Antonio Candido no artigo "Os primeiros baudelairianos", a leitura das Flores do mal foi decisiva para que Teófilo Dias, Fontoura Xavier e Carvalho Jr. conseguissem romper com a poesia romântica.

Impregnado de literatura nova, Aluísio Azevedo voltou a S. Luís em agosto de 1878, em virtude da morte do pai. Na província, colaborou em jornais alternativos (financiados pela maçonaria) em que atacou com virulência o Trono, a Igreja e os comerciantes portugueses. Em 1881 publicou $O$ mulato, que foi considerado o primeiro romance naturalista brasileiro, a despeito do Romantismo difuso que ainda continha. Se, em São Luís, essa obra proporcionou alguns dissabores ao autor pela reação indignada de certos maranhenses que se julgaram retratados por personagens perversas ou ridículas, conquistou-lhe, no Rio de Janeiro, ao contrário, o apreço 
da crítica e dos leitores. Estimulado por essa recepção positiva, Aluísio Azevedo decidiu retornar à Corte.

De 1882 a 1895, Aluísio Azevedo viveu exclusivamente da pena, tornando-se, portanto, escritor profissional. Para realizar essa façanha sem precedentes no Brasil, necessitou colaborar intensamente na imprensa, escrever e traduzir peças para o teatro, produzir folhetins e publicar romances em grande quantidade (para os padrões da época). ${ }^{3}$ A imprensa, que se expandia graças às campanhas em prol da República e da Abolição, oferecia muitas oportunidades de trabalho intelectual.

Em meados da década de 1880, o grupo de Patrocínio ${ }^{4}$ sofreu alguns desfalques importantes. Haviam morrido Artur de Oliveira (1882) e Artur Barreiros (1885); Teófilo Dias e Fontoura Xavier mudaram-se, respectivamente, para São Paulo e Rio Grande do Sul. No entanto, jovens intelectuais que se engajavam no jornalismo, voltando as costas às carreiras tradicionais, aderiram ao grupo atraídos pelo carisma de Patrocínio, que inclusive empregaria alguns de seus amigos nos jornais que dirigiu, Gazeta da Tarde (1881-1887) e Cidade do Rio (1887-1902). No final da década, gravitavam, em torno do grande jornalista, Paula Nei (1858-1897), Luís Murat (1861-1929), Coelho Neto (1864-1934), Guimarães Passos (1867-1909), Emílio de Meneses (1866-1918), Pardal Mallet (1864-1895), Raul Pompeia (1863-1895), Pedro Rabelo (18681905) e Olavo Bilac (1865-1918).

Esse grupo relativamente numeroso, que se reunia alegre e ruidosamente em cafés e confeitarias durante o dia e à noite em ambientes menos familiares, permaneceu coeso até alcançar a grande conquista da Abolição. ${ }^{5}$ Como discordaram de Patrocínio, que deci-

3 A tiragem de um livro não ia geralmente além de quinhentos exemplares. No caso dos romances do autor de $O$ mulato, a tiragem de cada edição era de mil exemplares.

4 Não adotamos aqui o tradicional conceito de geração literária, porque o de grupo de escritores transcende a questão etária e corresponde melhor à organicidade do conjunto de "boêmios" liderados por Patrocínio (cf. Escarpit, 1964, p.37).

5 Sobre esse período da "geração boêmia", v. Coelho Neto (1921). 
diu então apoiar a continuidade da monarquia com a princesa Isabel no trono, Olavo Bilac, Pardal Mallet, Luís Murat e Raul Pompeia deixaram a Cidade do Rio e fundaram o jornal A Rua (1889) para prosseguir sem constrangimentos na propaganda republicana.

Patrocínio aderiu ao novo regime somente quando, em novembro de 1889, os cavalos do Exército já desfilavam pelas ruas cariocas. Com isso, tornou-se viável a reconciliação do grupo, o que ocorreria imediatamente.

No país do patrimonialismo, nada mais natural do que receberem os propagandistas da véspera uma retribuição do regime que ajudaram a instituir. Assim, Aluísio Azevedo, Luís Murat, Coelho Neto, Pardal Mallet e Olavo Bilac tornaram-se em 1890 funcionários por indicação do governo do estado do Rio de Janeiro, então sediado em Niterói. Outros intelectuais também foram beneficiados pelos favores da jovem República.

Entretanto, a instabilidade do novo regime logo promoveria uma dança das cadeiras. O marechal Deodoro da Fonseca, líder da revolução e presidente da República, decidiu em 3 de novembro de 1891 fechar o Congresso Nacional que, após o desastre do Encilhamento (1890-1891), se recusava a aprovar certas medidas econômicas propostas pelo Executivo. $\mathrm{O}$ contragolpe não tardou. A articulação de congressistas nos estados, a resistência de civis e a oposição de elementos da Marinha e do Exército forçaram Deodoro a renunciar no dia 23 de novembro, quando assumiu o seu substituto constitucional, o vice-presidente Floriano Peixoto.

Para consolidar o seu poder, o novo presidente iniciou um processo ilegal de deposição das câmaras e governos estaduais que se calaram por ocasião do golpe contra o Congresso. O governador do estado do Rio de Janeiro, Francisco Portela, que apoiou Deodoro, foi destituído do cargo e, ato contínuo, foram exonerados os intelectuais por ele nomeados.

Desempregados no início de 1892, Olavo Bilac e Pardal Mallet uniram-se ao republicano histórico Lopes Trovão para fundar o jornal $O$ Combate, que não daria trégua ao novo presidente e seu principal aliado, o ministro da Marinha Custódio José de Melo. 
Com a nova conjuntura política, passaram a ocorrer dissensões no interior do grupo de Patrocínio. Raul Pompeia, que ficara ao lado de Floriano, desentendeu-se com Bilac, com quem ensaiou um duelo cancelado à última hora.

Em abril de 1892, simpatizantes de Deodoro conspiravam abertamente contra Floriano. No dia 10 daquele mês, ocorreu manifestação popular pela volta do presidente deposto. Floriano reagiu rápido e prendeu as lideranças do movimento, entre as quais se contavam Pardal Mallet, Olavo Bilac e José do Patrocínio.

Apesar da anistia decretada em agosto de 1892, o país ainda não experimentaria a estabilidade política. Sentindo-se prejudicado em suas pretensões à presidência por articulações em andamento, Custódio José de Melo demitiu-se do ministério e, em setembro de 1893, sublevou a Armada. Era o início da guerra civil que, se não tomou grandes proporções, afetou seriamente a vida da população civil. Os jornais foram impedidos pelo governo de noticiar ou comentar o conflito, os veículos que desafiaram a censura foram fechados e seus redatores foram presos ou desterrados. José do Patrocínio, da Cidade do Rio, foi desterrado para o Amazonas; Bilac, que então trabalhava na Gazeta de Notícias, refugiou-se em Ouro Preto; Pardal Mallet fugiu para o interior fluminense; Guimarães Passos e Luís Murat exilaram-se em Buenos Aires. Além de Pompeia, mantiveram-se fiéis ao Marechal de Ferro Artur Azevedo, Paula Nei e Araripe Jr. (1848-1911). O grupo de Patrocínio estava, portanto, cindido em dois blocos inconciliáveis. ${ }^{6}$

Floriano Peixoto sufocou a Revolta da Armada e a subsequente Revolução Federalista, mas, para surpresa de muitos, não tramou

6 Fato eloquente a esse respeito foi a dissolução do Club Rabelais, criado por Raul Pompeia em agosto de 1892 para reunir em almoço ou jantar um grupo de amigos na segunda sexta-feira de cada mês. Araripe Jr., um dos comensais, testemunhou o melancólico fim da agremiação. "O Rabelais teve vida curta, durando somente ano e meio. Interrompido pelos acontecimentos da revolta de 6 de setembro de 1893, quando depois se reuniu pela primeira vez, verificou-se que a alegria e cordialidade dos seus membros estavam profundamente modificadas. Havia entre eles custodistas e jacobinos. [...] Nesse ágape, os rabelaisianos estranharam-se." (Araripe Jr., 1970, v.5, p.23) 
para perpetuar-se no poder. Em 1894, aceitou ceder a Presidência a Prudente de Morais, um civil que representava os interesses dos poderosos cafeicultores paulistas.

Pacificado o país, os intelectuais voltaram ao Rio para retomar suas carreiras literárias. Além de Gazeta de Notícias, O País, Diário de Notícias, Jornal do Comércio e Cidade do Rio, que já empregavam muitos escritores, estreou em 1894 o vespertino A Notícia, que formou uma respeitável equipe de redatores e colaboradores remunerados.

Quando as condições para o trabalho intelectual começavam a melhorar sensivelmente, inclusive por um discreto aumento do público leitor, Aluísio Azevedo, que já era um escritor profissional, abandonou a liça. Aprovado em concurso público para a carreira diplomática, assumiu em 1895 o posto de vice-cônsul em Vigo e nunca mais publicou um livro sequer. ${ }^{7}$

Entretanto, houve dois sucessores à sua altura. Bilac tornou-se um dos mais prestigiados cronistas do jornalismo carioca. Não foi por acaso que em 1897 substituiu Machado de Assis na crônica semanal da Gazeta de Notícias. Além disso, continuou vendendo muito bem seus livros de poesia e coletâneas de crônicas e contos, criou anúncios publicitários em versos e iniciou-se com muito êxito, em companhia de Coelho Neto e Manuel Bonfim, no lucrativo segmento do livro paradidático. Note-se de passagem que Bonfim, pelos cargos que ocupou na Educação, pôde, como bom amigo que era, garantir a inclusão dos livros do poeta nas compras do governo.

Coelho Neto, outro sucessor de Aluísio Azevedo, notabilizou-se como um dos mais prolíficos escritores da literatura brasileira. Além de colaborar abundantemente na imprensa, experimentou suas forças em diversos gêneros. Em 1894, firmou com o editor Domingos de Magalhães, da Livraria Moderna, um contrato que lhe renderia 400 mil réis mensais ao longo de cinco anos. ${ }^{8}$ Ao morrer em 1934, deixou 112 obras publicadas, além de cinquenta peças de teatro.

7 Sobre a carreira de Aluísio Azevedo, v. Mérian (1988, cap.25).

8 Essa quantia representava cerca de dez vezes o salário de um operário qualificado. 
Enquanto a carreira de seus antigos companheiros ascendia, Raul Pompeia era seriamente prejudicado por sua paixão política. Por ocasião do sepultamento de Floriano Peixoto no dia 29 de setembro de 1895, o autor de $O$ Ateneu proferiu um violento discurso contra os adversários políticos do marechal. Prudente de Morais, que comparecera ao cemitério, não gostou da ousadia e impôs a demissão do romancista, que então dirigia a Biblioteca Nacional. Dias depois, o discurso ainda rendia dissabores a Pompeia. Luís Murat, seu amigo em outros tempos, publicou em outubro daquele ano um artigo cujo título, "Um louco no cemitério", não deixava dúvidas sobre a avaliação que fazia do episódio. Deprimido por essas e outras contrariedades, Raul Pompeia deu um tiro no peito em plena noite de Natal. Não pôde assim ser incluído entre os fundadores da Academia Brasileira de Letras, inaugurada em 1897. Do grupo de boêmios da década de 1880, receberam essa consagração Artur Azevedo, Coelho Neto, Guimarães Passos, Luís Murat, Olavo Bilac, Pedro Rabelo, Valentim Magalhães e José do Patrocínio. ${ }^{9}$

Em 16 de julho de 1898, os escritores brasileiros realizaram um antigo desejo coletivo com a aprovação pelo Congresso Nacional de uma lei de direitos autorais, que os protegeria dos abusos de jornais e editoras.

No final do século XIX, a República já havia vencido os seus inimigos reais ou imaginários, entre os quais se contavam os pretensos monarquistas encastelados em Canudos. No entanto, a vida do país não melhorara sensivelmente com o novo regime e a Capital Federal ainda era essencialmente a mesma cidade de vias estreitas, decadentes e sujas legada pelo Império. Para piorar a situação, o porto não atendia à demanda do comércio de mercadorias e matérias-primas e a população sofria com epidemias e endemias, das

9 O espírito de associação dos escritores cariocas já havia rendido iniciativas similares como a Associação de Homens de Letras (1883), o já mencionado Club Rabelais (1892-1893) e o chá das quatro na redação da Revista Brasileira (1895-1896), do qual sairia o principal grupo dos fundadores da ABL (cf. Neves, 1940, p.5-9). 
quais a febre amarela era considerada a mais importante por atingir principalmente os estrangeiros, afastando-os da cidade.

Das tribunas que ocupavam nos jornais, os intelectuais empenharam-se numa campanha sem tréguas pelo saneamento e pelo embelezamento da cidade, clamando por medidas enérgicas que transformassem radicalmente o Rio de Janeiro. Não aceitavam que a Capital Federal continuasse a ser conhecida por Cemitério dos Estrangeiros ou fosse ainda considerada a cidade mais suja da América Latina.

Quando a administração do prefeito Pereira Passos (19021906) iniciou o Bota-Abaixo, que literalmente arrasou quarteirões e desalojou milhares de trabalhadores pobres para construir novas avenidas, alargar ruas antigas e abrir novas praças, a maioria dos intelectuais apoiou incondicionalmente as reformas, que davam ares europeus ao centro da cidade e à população que nele morava, pois os novos prédios de aço e cristal seriam ocupados por uma elite predominantemente branca.

Durante a Revolta da Vacina, em que, armados de paus e pedras, os excluídos dos planos regeneradores da prefeitura enfrentaram a polícia, a guarda nacional, o corpo de bombeiros e tropas do Exército, os intelectuais proferiram em uníssono protestos indignados contra a irracional reação dos que se opunham a uma reforma fundamental para a saúde pública e a modernização urbanística da cidade.

Nesse momento crucial para o predomínio político das oligarquias, os homens que dirigiam o Estado contaram com o apoio decisivo dos intelectuais que, dos jornais e revistas, formavam a opinião pública. Não fora, portanto, mal empregado o dinheiro com que, desde dezembro de 1900, o Estado custeava publicações e despesas postais da Academia Brasileira de Letras, além de abrigá-la em prédio próprio (cf. Neves, 1940, p.38).

Olavo Bilac, o principal cronista carioca e o defensor mais intransigente da Regeneração (Sevcenko, 1998, p.576), fora em 1899 nomeado inspetor escolar do Rio de Janeiro e, em 1906, recebeu a honrosa incumbência de responder pela secretaria-geral da III Conferência Pan-Americana, realizada no Rio de Janeiro. Nos anos 
subsequentes, Bilac voltaria a receber importantes missões e vultosas comissões do Itamarati, chefiado pelo barão do Rio Branco.

Em 1907, o poeta das Panóplias (1888) foi homenageado por seus vinte anos de jornalismo. Compareceram ao banquete, realizado no Palace Theatre, o marechal Hermes da Fonseca, o prefeito Sousa Aguiar, o senador Pinheiro Machado, eminência parda da República, e o ex-prefeito Pereira Passos, além de escritores importantes como Machado de Assis. Em seu discurso de agradecimento, Bilac transformou, muito habilmente, a consagração pessoal em homenagem ao grupo de escritores a que pertencia. Em lugar da autolouvação de seus méritos, preferiu destacar a grande realização coletiva.

Que fizemos nós? Fizemos isto: transformamos o que era até então um passatempo, um divertimento, naquilo que é hoje uma profissão, um culto, um sacerdócio; estabelecemos um preço para o nosso trabalho, porque fizemos desse trabalho uma necessidade primordial da vida moral e da civilização da nossa terra; forçamos as portas dos jornais e vencemos a inépcia e o medo dos editores... (Bilac, 1927, p.78)

De fato, no início do século XX a produção intelectual deixou de depender exclusivamente do ócio proporcionado por respeitáveis profissões burguesas e passou a contar com a resposta estimulante do público leitor, que adquiria livros e assinaturas dos periódicos em quantidade razoável em decorrência do acentuado crescimento populacional do Rio de Janeiro e de discreta ampliação do percentual de alfabetizados. Além disso, o Estado, ao perceber a ascendência dos intelectuais sobre a opinião pública, decidiu-se a cooptar os escritores mais importantes mediante cargos públicos, prebendas e outras benesses. ${ }^{10}$ Os conflitos da primeira metade da déca-

10 Trata-se do mecenato de Estado, que se traduz em pensões mais ou menos regulares ou funções oficiais. As sinecuras burocráticas são uma forma de mecenato (cf. Escarpit, 1964, p.48). 
da de 1890, que tanto prejudicaram os intelectuais, haviam sido decorrentes da ocupação conjuntural do poder político por quem não detinha o poder econômico. Vencidos os nostálgicos do antigo regime e os radicais que sonhavam com uma República ideal, as oligarquias fortalecidas no poder empenharam-se em constituir os seus intelectuais orgânicos (v. Gramsci, 1979, p.3-12). Iniciava-se a era da literatura-sorriso-da-sociedade.

O jovem romancista e contista Afonso Henriques de Lima Barreto, que estreou no início do século $\mathrm{XX}$, sentia náuseas diante da frequente submissão da atividade intelectual a interesses subalternos e, por isso, tomou a corajosa e louvável decisão de sacrificar tudo para dignificar a profissão de escritor. Como se sabe, pagou um alto preço por sua audácia e independência. Mas essa é outra história. 


\section{2 \\ LOCALISMO E COSMOPOLITISMO NAS REVISTAS DE ANO ${ }^{1}$}

No "panorama para estrangeiros" esboçado no ensaio "Literatura e cultura de 1900 a 1945 ", escrito na primeira metade da década de 1950, Antonio Candido defendeu a tese de que a vida espiritual brasileira seria regida pela dialética do localismo e do cosmopolitismo. Em movimento pendular, alternar-se-iam momentos de "afirmação premeditada e por vezes violenta do nacionalismo literário" e períodos de "declarado conformismo", marcados pela "imitação consciente dos padrões europeus" (Candido, 1985, p.109). O Romantismo e o Modernismo seriam momentos decisivos de "afirmação do particularismo", de valorização da cultura nacional. Já o período que Candido nomeava de pós-romântico, que iria, grosso modo, de 1880 a 1922, seria manifestação de conformismo cosmopolita, de aceitação e imitação passiva dos modelos culturais europeus, a despeito do equilíbrio de Machado de Assis e Joaquim Nabuco e do sopro de renovação representado por Euclides da Cunha, Monteiro Lobato, Augusto dos Anjos e Lima Barreto.

O Parnasianismo, como corrente hegemônica na poesia pós-romântica, reeditava concepções neoclássicas que impunham um

1 Dedica-se este ensaio a Marilene Weinhardt. 
estilo elevado, depurado de prosaísmos, gírias, regionalismos e neologismos. No bojo dessa separação de estilos, alguns gêneros literários cultivados na imprensa foram considerados menores ou desprezíveis pela temática abordada e pelo registro coloquial adotado. Tal concepção confinou às páginas dos periódicos a maior parte das crônicas, da poesia satírica e humorística e dos folhetins folhetinescos do período, que foram considerados por seus próprios autores indignos de figurarem nas páginas dos livros, reservados para a literatura séria.

Para o teatro, a crítica militante preconizava a mesma separação de estilos e aferrava-se a um cânone formado por autores como Corneille, Racine, Molière e Shakespeare. Quando se dignava a considerar o teatro brasileiro, não ia muito além de Alencar, Martins Pena e Castro Alves. Para os severos guardiães do teatro, que pontificavam nas folhas diárias, as formas respeitáveis eram a tragédia, o drama, a ópera e a (boa) comédia. No entanto, as salas teatrais cariocas eram monopolizadas por "gêneros menores" como a opereta, a mágica, o vaudeville e, principalmente, a revista de ano.

Nas revistas de ano, notava-se a tensão característica da dialética do localismo e do cosmopolitismo, que surge do confronto entre os conteúdos nacionais e os moldes culturais herdados da Europa. Entretanto, a forma cosmopolita dessas peças de grande espetáculo não sufocava a afirmação particularista da cultura brasileira; muito pelo contrário, distendia-se ou deformava-se sob a pressão das sugestões locais.

Embora europeia, a revista de ano não era uma forma dramática respeitada pelos críticos; tal fato devia-se provavelmente a sua origem popular, pois nasceu no século XVIII nas barracas das feiras parisienses de Saint-Laurent e Saint-Germain.

No Brasil, as primeiras montagens de revistas de ano não foram bem-sucedidas. As surpresas do senhor José da Piedade (1859), primeira revista brasileira, atribuída por Lafayette Silva a Justino Figueiredo Novais (1829-1877), foi proibida pela polícia após três representações pelas críticas que continha. Essa forma dramática consolidou-se somente com a hegemonia do teatro cômico e 
musicado, ${ }^{2}$ iniciado pelo café-concerto Alcazar, que foi inaugurado pelo artista francês Joseph Arnaud na Rua da Vala, atual Uruguaiana, em 1857. A chegada em 1864 de um grupo de artistas francesas revitalizou a sala de espetáculos, que abrigou alguns sucessos, como Orphée aux enfers, ópera-bufa ou opereta em quatro atos de Offenbach, que tendo estreado em 1865 manteve-se no cartaz por quatrocentas noites. Os trajes ousados das cantoras e das dançarinas do arrebatador cancã talvez fossem em grande parte responsáveis pelo sucesso. A estrela absoluta daquele palco foi Aimée, que despertou nos cariocas paixões irresistíveis e ruinosas. ${ }^{3}$ Suas sucessoras foram

2 A história do teatro brasileiro foi sensivelmente condicionada pelo prestígio popular de formas como a opereta e a revista de ano, como informa um dos maiores especialistas no assunto: "Ao Realismo, se a história tivesse lógica, seguir-se-ia o Naturalismo, como aconteceu na França, e no que diz respeito ao romance também no Brasil, com Aluísio Azevedo sucedendo a José de Alencar. Mas nos palcos do Rio de Janeiro, cidade que concentrava praticamente todo o teatro nacional, essa sequência foi interrompida por uma espécie de avalanche de música ligeira, que arrasou o pouco que o Romantismo e o Realismo haviam conseguido construir sob a designação de drama. A irrupção da opereta francesa, acompanhada por suas sequelas cênicas, trouxe consigo a morte da literatura teatral considerada séria. Não se deixou por isso de pensar sobre o Brasil - e sobre o que mais poderíamos pensar? - porém em termos de comédia ou de farsa, em continuação a Martins Pena, não a Castro Alves ou Alencar. Tal inflexão foi condenada por todos os interessados, - autores, intérpretes, críticos, - menos pelo público, que de qualquer forma nunca dera atenção aos nossos escritores" (Prado, 1999, p.85).

3 Ao discorrer sobre a prostituição no Segundo Império, Gastão Cruls destacou a proeminência das francesas, que eram muito mais acessíveis aos galanteios. A mais amada delas era justamente uma alcazarina: "Entre tantas mundanas que por aquela época, como sempre, hão de ter afogueado paixões, mas que se perderam no anonimato, uma houve que pelas suas altas proezas amorosas e a récua de adoradores e chichisbéus que trazia à rabadilha, levou o nome aos jornais e à página de livros. Foi a Aimée. Estrela de primeira grandeza no elenco do Alcazar, a sua longa permanência no Rio tornou-se o desespero de muita esposa e a intranquilidade de muita mãe. Tanto assim que, quando daqui partiu, levando de 'economias' mais de um milhão e meio de francos, as senhoras mais respeitáveis de Botafogo, mal dominando o contentamento, vieram para a praia soltar foguetes, enquanto o vapor se ia em direção à barra, levando a famosa loureira. Em compensação, houve muito desconsolo entre os seus afeiçoados" (Cruls, 1949, p.419). 
Angèle Chartou, Marta Lafourcade, Delmary, Rose Marie (depois chamada de Rose Meryss), Leonor Rivero e Suzana Castera (cf. Silva, 1938, p.355 e Faria, 1993, p.XVII-XVIII). Segundo um frequentador do teatro, nem mesmo as senhoras respeitáveis resistiram à sedução da ópera-bufa... e da sala de espetáculos. Para atraí-las, organizou-se uma soirée de familles, da qual foram cuidadosamente excluídas as chamadas mulheres de vida alegre. A estratégia foi bem-sucedida, segundo o depoimento de um contemporâneo:

Foi preciso repetir muitas vezes as soirées de famille, a que todo o Rio de Janeiro sério concorreu. E o Orfeu invadiu a cidade toda, diluído em quadrilhas, em marchas, em polcas, tocado pelos pianos e pelos realejos, e até pelos sinos das igrejas. (Velhote, 1896, p.1)

Pode-se afirmar que o Alcazar inventou a vida noturna do Rio de Janeiro e constituiu-se em fator de arejamento dos costumes. Com o passar dos anos, os teatros transformaram-se no epicentro da vida boêmia carioca e tornaram-se lugares privilegiados para encontros amorosos, que ocorreriam preferencialmente nos chamados jardins que cercavam certas salas de espetáculo. Em poema satírico publicado em 1896, Olavo Bilac descreveu sinteticamente o que flagrara em visita a esses locais:

Fui do jardim do Apolo ao jardim do Recreio

E ao do Lucinda. Vi moças de farto seio;

Vi senhores de olhar cúpido e ardente; vi

Tanta gente passar, às tontas por ali!

Vi namoro, e chalaça, e farsas, e bebidas,

E mais nada...

(Lúcifer, 1896, p.7)

Paródia do mito de Eurídice e Orfeu, a peça de Offenbach foi por sua vez parodiada por Francisco Correia Vasques (1829-1892) em Orfeu na roça (1868), que ficou um ano em cartaz. Um historiador do teatro brasileiro apontou as possíveis causas do sucesso: 
Nas mãos do Vasques, pobres de literatura, mas ricas de experiência de palco, Orfeu aparece sob as vestes de Zeferino Rabeca; Morfeu, o deus do sono, transforma-se num nacionalíssimo Joaquim Preguiça; e Cupido passa a responder pelo irresistível nome de Quim-Quim das Moças. O êxito da fórmula, casando França e Brasil, Offenbach e Martins Pena, foi fulminante. (Prado, 1999, p.95)

Logo depois, a opereta passou a ser cultivada por autores brasileiros, que produziram traduções, adaptações e paródias. La grande-duchesse de Gérolstein transformou-se em A baronesa de Caiapó; Barbe-Bleu, em Barba de milho e Traga-moças; La fille de Madame Angot, em A filha de Maria Angu. Artur Azevedo, autor desta última adaptação, escreveu os textos originais de Os noivos e A princesa dos cajueiros (ambas de 1880).

Também musical, o vaudeville beneficiou-se da voga do teatro cômico e musicado. Essa forma dramática, mais antiga que a revista, fundamenta-se em situações complicadas como coincidências extraordinárias, quiproquós e equívocos. As canções eram de fácil assimilação, pois apoiavam-se em estribilhos ou bordões.

Ainda na esteira do chamado trololó, popularizou-se a mágica ou féerie, que dependia de uma representação de cenários e figurinos luxuosos, repleta de truques e surpresas. Algumas de suas personagens poderiam ser seres sobrenaturais como diabos e fadas. Carpinteiros, pintores, figurinistas, contrarregras e cenógrafos asseguravam bons efeitos visuais para o espetáculo, simulando no palco erupções, inundações, ciclones e o próprio fogo do inferno.

A revista de ano tornou-se a forma mais popular do chamado teatro ligeiro porque reunia a grande orquestra e as dançarinas de cancã da opereta, a comicidade e as cançonetas do vaudeville e a sofisticada cenografia da mágica. Essa modalidade de espetáculo passava em revista os principais fatos e personalidades do ano, submetendo-os ao tratamento impiedoso da sátira. A revista poderia ser encenada nos últimos meses do ano ou nos primeiros do ano seguinte. Compunha-se de três atos divididos em vários quadros; 
ao final de cada ato, encenava-se uma apoteose $\mathrm{em}^{4}$ homenagem a um brasileiro ilustre, a algum fato histórico, às riquezas do país ou a alguma instituição. A primeira revista de sucesso foi $O$ mandarim (1884), de Artur Azevedo e Moreira Sampaio.

Como autor de revistas, Azevedo consolidou as convenções dessa forma dramática. A fragmentada ação, dispersa em inúmeros quadros, era unificada por um enredo elementar. $\mathrm{O}$ compère $\mathrm{e}$, às vezes, a commère, presentes em todos os quadros, percorriam a cidade em busca de alguém ou alguma coisa. Em seus passeios, encontravam personagens ou situações que haviam marcado o ano transcursado. Para abordar determinados problemas, Artur Azevedo criava personagens alegóricas que representavam, por exemplo, o câmbio, a febre amarela, o jogo do bicho etc. A metalinguagem, característica permanente das revistas, era assegurada pelo quadro dos teatros e por personagens como Frivolina, musa das revistas, e o monsieur du parterre, que, introduzido previamente entre o público, intervinha inesperadamente para fazer observações, críticas ou protestos indignados.

Em consonância com as tendências cosmopolitas do período pós-romântico, Artur Azevedo e outros comediógrafos como Moreira Sampaio, Figueiredo Coimbra, Valentim Magalhães, Oscar Pederneiras, Augusto Fábregas e Vicente Reis importaram uma forma dramática europeia. Entretanto, as vigorosas raízes populares da revista de ano favoreceram sua aclimatação às condições brasileiras ou, mais especificamente, cariocas. Os problemas abordados eram os que mais incomodavam a população do Rio de Janeiro: carestia, deficiências do abastecimento de carne fresca, produtos alimentícios adulterados, falta de moradia, aluguéis exorbitantes etc. Muitas personagens eram tipos característicos da cidade como o português, o malandro, a mulata sensual, a mulher fatal e o matuto inadaptado à vida urbana.

4 A apoteose era, na maioria das vezes, independente da ação dramática e envolvia toda a companhia, mas dependia essencialmente da criatividade de carpinteiros, maquinistas, cenógrafos e figurinistas (v. Veneziano, 1991, p.109-13). 
Sem qualquer compromisso com as convenções tradicionais do teatro, os revisteiros espalhavam suas personagens pela cidade, cujos logradouros mais característicos eram vistos de vários ângulos. Criava-se, assim, um vasto panorama social do Rio de Janeiro, que era, inclusive, fiel à multiplicidade linguística dos cariocas. Nas revistas, registravam-se a fala característica dos caipiras, as colocações pronominais típicas do Brasil, os neologismos, os estrangeirismos, as gírias e até mesmo as obsessões puristas de gramáticos como Castro Lopes, caricaturado com a personagem Dr. Sabichão, da revista $O$ carioca, de Artur Azevedo, encenada em dezembro de 1886 (cf. Valença, 1986, p.225-52).

No entanto, a modificação mais original e significativa introduzida pelos brasileiros na revista de ano foi a substituição do cancã por um ritmo sincopado, formado nas ruas do Rio de Janeiro, que deu espontaneamente forma local ao erotismo das cançonetas maliciosas e ambíguas. Esse ritmo, antecessor do samba, era o maxixe, que, segundo José Ramos Tinhorão (1974, p.53), nasceu da dança:

[...] o maxixe resultou do esforço dos músicos de choro em adaptar o ritmo das músicas à tendência aos volteios e requebros de corpo com que mestiços, negros e brancos do povo teimavam em complicar os passos das danças de salão.

Em lugar da ginástica europeia do cancã, impunha-se, portanto, uma complexa dança requebrada e sensual de indisfarçáveis raízes africanas.

À medida que o maxixe predominava nas revistas, recrudesciam as queixas da crítica especializada e dos literatos em geral quanto a uma suposta "decadência" do teatro brasileiro. Não obstante, tais queixas remontavam à década de 1870, quando o Alcazar imperava absoluto, levando o desânimo aos que sonhavam com o teatro literário. Em 1873, a cena teatral carioca já deixava o crítico Machado de Assis desalentado, conforme se notava em fragmento do ensaio "Notícia da atual literatura brasileira: instinto de nacionalidade" (Assis, 1997, v.3, p.808): 
Hoje, que o gosto público tocou o último grau da decadência e perversão, nenhuma esperança teria quem se sentisse com vocação para compor obras severas de arte. Quem lhas receberia, se o que domina é a cantiga burlesca ou obscena, o cancã, a mágica aparatosa, tudo o que fala aos sentimentos e aos instintos inferiores? ${ }^{5}$

No final do século XIX, quando o maxixe invadia o palco, a imprensa debatia intensamente o problema da decadência do teatro nacional. Artur Azevedo, crítico teatral do vespertino A Notícia, não podia ficar indiferente à questão e fazia o mesmo diagnóstico alarmista. Sua situação era, no entanto, esquerda, pois fora um dos principais responsáveis pelo sucesso do teatro cômico e musicado e, particularmente, das revistas de ano, que continuava a cultivar quase sempre com êxito de público.

Em 10 de fevereiro de 1898, Coelho Neto escreveu violento artigo em que acusava Artur Azevedo de haver quebrado sua palavra de não mais escrever revistas de ano após o fracasso de Fantasia (1897), que o dramaturgo maranhense considerava sua revista mais sofisticada. Naquele mês, estreara no Teatro Recreio Dramático O jagunço, revista do ano de 1897 escrita pelo mesmo autor de $O$ tribofe. Para Coelho Neto, O jagunço seria, como todas as revistas, mero pretexto para trapalhadas e cenografias. O prolífico romancista denunciava a incoerência de quem pregava semanalmente pela regeneração do teatro nacional, mas desistia inesperadamente de sua cruzada e mancomunava-se a um empresário para cometer mais um "atentado contra o gosto do público".

No dia 17 de fevereiro, Artur Azevedo utilizou sua coluna de A Notícia, intitulada "O teatro", para defender-se. Em primeiro

5 Se, por um lado, o teatro ligeiro deprimia Machado, a cançonetista Aimée, por outro, deixava-o em estado de espírito completamente diverso, como se nota no retrato que o grande escritor dela pintou: "[...] um demoninho louro, uma figura leve, esbelta, graciosa, uma cabeça meio feminina, meio angélica, uns olhos vivos, um nariz como o de Safo, uma boca amorosamente fresca, que parece ter sido formada por duas canções de Ovídio" (apud Sousa, 1960, v.1, p.223). 
lugar, afiançava a qualidade de suas revistas, que continham cenas de comédia, observação e sátira de costumes e eram escritas com "alguma preocupação literária”. Justificou sua atividade de revisteiro com o argumento de que grandes autores franceses escreviam revistas. Garantiu não haver desistido da regeneração do teatro; prova disso seria sua campanha incansável pela construção do Teatro Municipal, que abrigaria, segundo sua concepção, uma escola normal de teatro. Assegurou também não haver escrito $O$ jagunço por razões pecuniárias, mas simplesmente para atender ao pedido de um amigo a quem devia favores. Sobre as exortações para que escrevesse peças literárias, afirmou que devia toda a sua fama de comediógrafo ao que Coelho Neto chamava de "chirinola"; todas as vezes que escrevera com preocupações artísticas fracassara fragorosamente. Por isso, não considerava justo impingir aos empresários, que viviam do teatro, peças literárias que seriam encenadas diante de cadeiras vazias.

O mais interessante na resposta de Artur Azevedo era sua avaliação de que o gênero das revistas de ano não era, a princípio, "pernicioso" desde que fosse "tratado com certa preocupação, relativa, de arte". Além disso, apontou incoerência em elogios que Coelho Neto havia feito à opereta: "não tens razão para dizer que a música dê um relevo gracioso à opereta e não o dê à revista. Por ventura o cancã é mais nobre que o maxixe? Não; apenas o maxixe ainda espera pelo seu Offenbach" (Azevedo, 1898, p.2). ${ }^{6}$

O maxixe das revistas não encontrou um compositor de repercussão universal como Offenbach, mas foi cultivado por músicos talentosos como Chiquinha Gonzaga, Assis Pacheco, Ari Barroso,

6 A polêmica havia-se iniciado em 1897 com artigo publicado em Juiz de Fora por Coelho Neto, que continha farpas indiretamente endereçadas a Artur Azevedo. O comediógrafo vestiu a carapuça e respondeu às críticas na sua seção do vespertino A Notícia. Naquele mesmo ano, o famoso romancista escreveria o drama Pelo amor, representado pelos amadores do Recreio Dramático em setembro de 1897. Meses depois, encenar-se-ia na cidade Amor ao pelo, pachouchada de "um poeta que deseja[va] guardar o anônimo e as porcentagens”. A paródia, como logo se soube, fora escrita por Artur Azevedo (cf. Mencarelli, 1999, p.75-93). 
Sinhô, Pixinguinha, Lamartine Babo, Noel Rosa e Ernesto Nazareth, que, segundo Tinhorão (1974, p.65), foi "o primeiro compositor brasileiro a estilizar o ritmo do maxixe". Muitas canções das revistas deixavam o palco e passavam a ser cantadas nas ruas do Rio de Janeiro. O primeiro sucesso foi o lundu amaxixado Araúna ou Chô-Araúna da revista Cocota, de Artur Azevedo, encenada em 1885. No entanto, o maior sucesso foi o tango ${ }^{7}$ As laranjas de Sabina, da revista República, escrita pelos irmãos Artur e Aluísio Azevedo (Mencarelli, 1999, p.154-5). Quando as revistas de ano deram lugar ao teatro de revista, ${ }^{8}$ consolidou-se definitivamente a associação entre o teatro e a música popular brasileira. Herdeira, por sua vez, do teatro de revista, a chanchada cinematográfica prosseguiu na divulgação de artistas e compositores brasileiros.

Essa abertura para a cultura popular concretizava exemplarmente o potencial de renovação estética das revistas de ano. Enquanto os romancistas concebiam a literatura como documento, seguindo os passos de Zola e Eça de Queiroz, os revisteiros empregavam a metalinguagem e a paródia e abusavam da fantasia. Enquanto os poetas parnasianos adotavam uma linguagem depurada, os autores de revistas de ano incorporavam ao seu texto variantes regionais e sociais, privilegiando sempre um registro coloquial. Enquanto os críticos de teatro consideravam menores as formas típicas do teatro cômico e musicado, autores como Artur Azevedo e Moreira Sampaio cultivavam com cuidados especiais a revista

7 Segundo Tinhorão (1974, p.63 e 87), o tango brasileiro seria uma música de andamento rápido surgido da fusão da música do teatro ligeiro e de danças estrangeiras que se abrasileiravam. Esse historiador da música brasileira informava ainda que a designação tango recobriu durante muito tempo o tipo de música que já acompanhava a dança do maxixe.

8 A revisão dos fatos do ano, essencial à revista, passou a ser feita em intervalos mais curtos no teatro de revista. Preservando da revista de ano a comicidade e a sátira aos costumes e ao mundo da política, a nova forma fixou-se em dois atos e adotou uma sucessão de quadros e cenas bem distintos e relativamente soltos. Nela enfatizou-se ainda mais a encenação espetacular, o carisma dos grandes cômicos e a exposição dos atributos físicos das belas vedetes (cf. Guinsburg et al., 2006, p.270-1). 
de ano, forma dramática flexível apta a captar as peculiaridades culturais do Rio de Janeiro que, como o maxixe, não encontravam correspondência nos países europeus. Desse modo, a revista de ano assegurava uma vigorosa e salutar manifestação de localismo no período pós-romântico, predominantemente cosmopolita, abrindo caminho para a eclosão do Modernismo. Ao contrário do que pensava a crítica militante, a revista não representava um sintoma de decadência cultural; era, na verdade, uma reação vigorosa do teatro brasileiro, que ia ao encontro de seu público. 


\section{3 \\ Entre Zola e Eça: o Naturalismo BRASILEIRO EM SEU APOGEU (1888) ${ }^{1}$}

... em 1881, surge $O$ mulato, acolhido com entusiasmo.

A vitória consolida-se em 1884, com a Casa de pensão, e em 1888 o Naturalismo atingiria o seu apogeu.

Lúcia Miguel Pereira

O primeiro romance brasileiro claramente naturalista foi $O \mathrm{mu}$ lato (1881), de Aluísio Azevedo, que aprendeu com Eça de Queirós a criar tipos e representar usos e costumes de sociedades provincianas. ${ }^{2} \mathrm{O}$ escândalo provocado em São Luís do Maranhão por essa obra praticamente obrigou seu autor a tentar a sorte no Rio de Janeiro, onde publicou em 1884 Casa de pensão, que ainda seguia

1 Este ensaio foi publicado pela primeira vez em 2012, no quarto volume da revista Olho d'Água (São José do Rio Preto), dirigida por Arnaldo Franco Junior.

2 Segundo Lúcia Miguel Pereira (1988, p.121), "só quando o Realismo se exagerou no Naturalismo e ganhou aquela rigidez agressiva que facilitou o êxito retumbante de Zola em França e Eça de Queirós em Portugal, é que se instalou definitivamente aqui, com Aluísio Azevedo. O modelo concreto conseguiu o que não haviam obtido nem as alterações do meio, nem os esforços dos críticos, nem as preferências dos leitores". 
Eça de Queirós no que respeita à caracterização de personagens, descrição do espaço e disposição para denunciar mazelas sociais. Em 1887, Aluísio Azevedo publicaria O homem, que seria dedicado ao estudo de um caso de histeria. Impedida de casar-se por cálculos e preconceitos de seu pai, Magdá, a protagonista, encontrava nos sonhos e nos delírios a satisfação erótica que a realidade negava-lhe. A dívida com Zola era evidente na adoção do modelo de romance experimental, na ênfase na fisiologia e na disposição polêmica de abordar com franqueza a sexualidade.

No ano de 1888, o Naturalismo brasileiro chegaria ao ápice com a publicação de seis romances: Hortência, de Marques de Carvalho; O missionário, de Inglês de Sousa; O cromo, de Horácio de Carvalho; A carne, de Júlio Ribeiro; Lar, de Pardal Mallet; Uma família baiana, de Xavier Marques. Importa considerar que aspectos das doutrinas e das obras de Zola foram diretamente apropriados pelos autores brasileiros nesse momento que, do ponto de vista histórico, seria marcante pela abolição da escravatura e pelo ocaso do Império.

Lar, de Pardal Mallet, narra a formação moral de Sinhá, típica moça da classe média do Rio de Janeiro. Amamentada por ama-de-leite, cresceu ao lado da colaça Chiquinha. Da madrinha, D. Perpétua, ouvia histórias bíblicas e contos de fada; a menina não fazia qualquer distinção entre as duas modalidades narrativas. No colégio, que para ela era mero pretexto para um passeio cotidiano, Sinhá convivia com as meninas maiores, que a introduziram nos mistérios do sexo. De volta ao lar, procurava instruir Chiquinha, o que o narrador resumiu em termos rudes.

Queria botar para fora esse feto espúrio aplacentado na membrana de suas convivências, - emprenhado do zoosperma dos colégios no útero das cozinhas; esse, nas regiões do lar, homólogo moral das baratas e das aranhas que germinam no mistério das porcarias. (Mallet, 1888, p.71)

Note-se, no fragmento, a condenação das cozinhas, que nas casas burguesas eram o espaço dos criados ou escravos, onde a moral 
burguesa não era observada e as meninas entravam em contato com valores e práticas considerados imorais.

Como episódio fundamental do amadurecimento fisiológico de Sinhá, o narrador relata o aparecimento de sua menarca: "por uma noite em que ela não dormiu, a lei indefectível e fatal do progredir orgânico rasgou-lhe lá bem no fundo das entranhas a ferida periódica dos fecundalismos e chuviscou-lhe gotas de sangue por sobre o cálice rubro de suas virgindades" (ibidem, p.103).

A notícia do evento na família põe em discussão a educação da moça. Por sugestão da madrinha, compra-se-lhe um piano. Pouco depois, Sinhá deixa o colégio. Os dois fatos, aparentemente distintos, mas comicamente entrelaçados, dão os contornos do papel social que se reservava às moças daquele tempo:

Também não precisava aprender mais nada! Lia correntemente, escrevia em belo cursivo arredondado de mulher e já sabia as quatro operações! Não tinha de ser nenhuma doutora e o que sabia chegava para que o homem da venda não a enganasse nas contas do fim do mês! (ibidem, p.189)

Considerada, pela família, pronta para casar, Sinhá passa a frequentar bailes e a fazer passeios em companhia de seu pai. A despeito de todo esse empenho, Sinhá encontrará o noivo ideal em Juca, vizinho e antigo companheiro de infância, que se formara em Farmácia. Seu Sardinha, pai de Sinhá, providencia o dinheiro para que o futuro genro possa estabelecer-se e, assim, o casamento viabiliza-se segundo práticas burguesas.

Lar vale por ser uma interessante crônica de costumes cariocas. Narram-se, por exemplo, as festas familiares em que se servia, por economia, vinho de cevada; o despertar da cidade com os bondes cheios de passageiros, vacas de leite perambulando pelas ruas, trabalhadores reunidos nos quiosques e escravos domésticos que saíam às compras de mantimentos; a leitura dos jornais, que desprezava as notícias sérias para concentrar-se nos folhetins; os namoros regidos pelas cartas e conselhos do Confidente dos namorados e inspirados 
pelos romances-folhetins; os bailes em clubes dançantes dirigidos pela burguesia.

O romance encerra-se com o casamento de Sinhá que, pouco antes de fechar-se no quarto com o noivo, recebe da mãe e da madrinha conselhos apropriados à ocasião: "Que necessidade tinha daqueles conselhos vagos e indefinidos, formulados a medo como quem limpa com o pé um pouco de porcaria e tem receio de sujar as botinas?! Sabia mais do que aquilo! E ria-se” (ibidem, p.274).

Pardal Mallet parece empenhar-se em demonstrar que a vida das castas donzelas contém muito mais curiosidade e descobertas precoces sobre o sexo do que se poderia suspeitar. Lar seria, assim, uma denúncia da hipocrisia da moral burguesa. Seu Naturalismo de matriz zolaniana residiria no interesse pelo desenvolvimento fisiológico de Sinhá e no modo franco de tratar do sexo.

Em Uma família baiana, de Xavier Marques, narra-se uma cilada que se arma a Luciano Pires, rico cafeicultor paulista que, em viagem a Salvador, fica hospedado na casa do coronel Antunes do Lago, financista e pai de Mafalda, moça em idade de casar-se. A convivência cotidiana entre a jovem e Pires inspira carta anônima, em que se acusava o coronel de ser complacente com a sedução da filha. Apesar da perfídia, a carta baseava-se no fato concreto de que Mafalda e Pires envolviam-se sentimentalmente. Concluindo que um casamento entre os dois poderia ser um grande negócio, o coronel Antunes, que era "audacioso para empreender as coisas, manhoso para dissimular, inonesto [sic] para não recusar meios" (Marques, 1888, p.74), forja carta anônima dirigida ao fazendeiro, a quem se alertava sobre os danos que sua estadia na casa do coronel estava causando à reputação de Mafalda. Antunes contava com que sua carta convenceria Pires a reparar a situação com um casamento em regra.

Marcado com efeito o casamento, entra em cena Juca, irmão de Mafalda, que esbanjava dinheiro com bebida e jogo. Quando sabe das aventuras do filho, o coronel fica alarmado por duas razões: um eventual escândalo poderia comprometer o casamento projetado e sua própria candidatura à diretoria do Banco Comercial. Não obstante, Juca passa a relacionar-se com Lúcia, costureira e filha 
de Valentina, que pedia esmolas pelas ruas de Salvador. A moça engravida, mas D. Teresa, a mãe de Juca e Mafalda, opõe-se a essa reparação porque a moça, além de pobre, era parda. O coronel resolve o problema com a sua inventividade, enviando aos jornais mofina em que se acusavam Valentina e Lúcia de explorarem a boa fé de moços incautos. O caso não modifica o comportamento de Juca que, sem dinheiro, contrai empréstimos vultosos assim como o estroina Brás Cubas, personagem de Machado de Assis. Esgotados todos os recursos, Juca rouba cadeia de ouro do hóspede, que descobre o furto, mas para poupar-se a aborrecimentos, cala-se, por desconfiar de empregada da casa.

D. Teresa, temendo a eclosão de um grande escândalo, ansiava pela realização do casamento de Mafalda e Pires e pela ida dos noivos a São Paulo, o que suscita comentários irônicos ao narrador:

Já se viu uma sogra desejar viver longe do genro, de boa vontade renunciar à tutela ilegal que todas se arrogam e dispensar a gostosa missão de reguladora da paz doméstica, ditando às jovens esposas quando devem destilar os ciúmes ou fazer explosão, fingir o arrufo ou lançar os pratos da mesa abaixo, dormir voltadas para a parede ou deixar os maridos ao relento. (ibidem, p.162)

Antes do casamento da irmã, ainda houve tempo de Juca ameaçar suicidar-se, o que revolucionou a casa e deixou Antunes e D. Teresa desesperados. Entretanto, Juca troca o melodramático suicídio, no qual nunca pensara seriamente, por uma prosaica bebedeira. Com sua encenação, consegue, não obstante, obter várias concessões dos pais à sua vida boêmia.

Na cerimônia de casamento de Mafalda e Luciano Pires, há abundância de comida, bebida e discursos. Juca aproveita a ocasião para tomar liberdades com as amigas da irmã, o que suscita ao narrador explicações naturalistas: "Quem o governava não era mais o livrinho das Regras de bem viver, era o seu sangue, seu instinto, sua animalidade fogosa, pruída incessantemente pelos desejos carnais" (ibidem, p.195). 
Após o casamento, Mafalda e Luciano Pires deixam a Bahia, onde Juca continua sua existência dissoluta. Pouco depois, chega a Salvador epidemia de cólera. Juca e D. Teresa apresentam os sintomas da doença e morrem. O coronel deixa a sua casa, flerta com uma das Castros, mulheres de seu círculo de amizades, mas decide afinal mudar-se para São Paulo a fim de fugir da epidemia.

Nas páginas finais, há uma cena decalcada do romance $O$ primo Basílio, de Eça de Queirós, em que Julião, que estivera ausente de Lisboa, vai à casa de Jorge e encontra-a fechada em decorrência da morte de Luísa. Depois, Julião encontra o amigo hospedado na casa de Sebastião. Em Uma família baiana, o professor Manoel dos Passos, que estivera acamado por vários dias, vai à casa do coronel Antunes, mas não encontra ninguém. Vem, depois, a descobrir o amigo hospedado na casa das Castros, onde se abrigara após as mortes da esposa e do filho.

Há outras marcas de Eça de Queirós no romance. No terceiro capítulo, as personagens são apresentadas coletivamente mediante uma reunião social, a exemplo do que ocorre em $O$ crime do padre Amaro e O primo Basílio. Além disso, o solene João Bernardo é uma espécie de conselheiro Acácio baiano.

Assim como em Lar, há no romance de Xavier Marques uma manifestação do narrador contra a promíscua convivência entre as donzelas burguesas e a criadagem: "Não há nada tão comum em certos lares onde se abriga a nossa combalida fidalguia, como se ver a gentil patroazinha, esquecida das conveniências a que noblesse oblige, cavaquear familiarissimamente com a criada manzorra e faladeira" (Marques, 1888, p.121).

Como consequência, a educação moral das moças ficava tacitamente a cargo das criadas: "é de todo natural que a noiva inexperiente fosse socorrer-se à experiência da $a m a$, pedindo à sabedoria dessa ignorante o que lhe faltava para ficar inteirada do papel, ativo e passivo, que tem a desempenhar uma senhora casada" (ibidem, p.122).

A típica família da elite baiana descrita por Xavier Marques está corrompida por imoralidade, egoísmo e hipocrisia. A cidade de 
Salvador, por sua vez, literalmente não cheira bem. Ao passar pela primeira vez perto da Misericórdia, Luciano Pires fica impressionado com o mau cheiro causado por fezes, lixo etc. A propósito, o narrador faz o seguinte comentário: "No entanto, digamo-lo por honrar as nossas tradições de desasseio [sic], o paulista não sabia da missa metade" (ibidem, p.41).

O romance Uma família baiana contém um ataque frontal aos críticos literários, "uma classe de escrupulosos cujos narizes estão sempre a farejar, nos livros modernos, o fartum dos canos de esgoto", mas que sempre se mostram tolerantes com as licenças da literatura antiga. A argumentação de Xavier Marques contra esses críticos é tipicamente naturalista: "Querem para seu deleite uma natureza mutilada, convencional, onde só haja perfumes, luz, saúde, beleza, bondade, virtude, grandioso, puro" [sic] (ibidem, p.123).

Entretanto, a despeito desses critérios estéticos naturalistas e da dívida evidente com Eça de Queirós, Uma família baiana é um romance movimentado e repleto de situações cômicas e/ou equívocas como um vaudeville.

Em Hortência, Marques de Carvalho documenta usos e costumes de Belém do Pará como a festa do Círio de Nazaré e a venda ambulante de açaí, mas seu propósito principal é narrar um caso de alcova, em que a protagonista é reduzida pelo próprio irmão, Lourenço, à condição de escrava sexual. De "frio temperamento" (Carvalho, 1989, p.68), Hortência aceita com fatalismo submeter-se à relação incestuosa. O sanguíneo Lourenço encontra no corpo da irmã a satisfação de seus "fantasiosos sentidos de mulato saudável" (ibidem, p.78).

Nessa caracterização da personagem, nota-se uma especificidade do Naturalismo brasileiro. A hereditariedade, concepção fundamental do ciclo dos Rougon-Macquart, passa a ser compreendida como pertencimento a uma raça. Para caracterizar o temperamento da personagem, o romancista vincula-a a uma determinada raça; a constituição psicofisiológica de seus ascendentes não é considerada relevante. Dessa perspectiva, o mestiço seria, via de regra, sensual, 
indisciplinado, preguiçoso, violento etc. Em Hortência, o mulato Lourenço, além de estuprar a irmã, envolve-se com mulheres casadas, rouba e espanca a mãe, briga com outros homens pelo privilégio de dormir com certas prostitutas, foge da polícia, abandona o trabalho para viver às custas da irmã, entrega-se à bebida e, finalmente, esfaqueia a irmã porque esta não lhe dera dinheiro.

Igualmente ambientado na região Norte do Brasil, o romance $O$ missionário, de Inglês de Sousa, foi provavelmente inspirado em $\mathrm{La}$ faute de l'abbé Mouret (1875), de Zola. Recém-egresso do seminário de Belém, no qual se destacara pela viva inteligência, o padre Antônio de Morais decide iniciar a sua carreira eclesiástica em Silves, pequena cidade que não dispunha nem mesmo de jornal. Idealista, o novo pároco procura desempenhar com denodo todas as suas funções sacerdotais. Entretanto, suas iniciativas são recebidas com indiferença ou até mesmo hostilidade pela maioria dos fiéis, que, não obstante, reconhecem as qualidades do religioso, entre as quais se destacava a castidade, justamente por ser delas a mais inusitada. Em desespero de causa, padre Antônio profere violento sermão contra o desprezo pela religião e contra as festas e licenciosidades da tradicional colheita das castanhas, que estava para iniciar-se. O sermão, em que se descrevem de modo vivo os castigos infernais, impressiona os fiéis, mas não impede que, logo depois, a cidade fique deserta com a fuga de boa parte da população para os castanhais.

Deprimido com o fracasso de sua pregação e espicaçado pelo escárnio de um livre-pensador local, que dizia não existirem padres brasileiros com coragem e abnegação suficientes para catequizar os índios, o padre concebe o projeto de ir em missão evangelizadora à aldeia dos mundurucus, índios antropófagos. Em companhia do sacristão Macário - que, contrariado, alimentava esperanças de dissuadi-lo a tempo da missão que lhe parecia insensata - o padre enfrenta inúmeros perigos e provações até ser abandonado em plena floresta amazônica por seu companheiro quando ambos se veem frente a frente com índios. Ao contrário do que julgara Macário, não são canibais, mas pacíficos índios catequizados, os que vão ao encontro do padre e, depois, levam-no para o seu sítio, onde o padre 
recupera as forças depauperadas. Nesse ambiente bucólico, que lhe lembrava da fazenda onde fora criado, o padre Antônio conhece a mestiça Clarinha, filha natural do padre João da Mata, que, quando vivo, costumava passar longos períodos de descanso naquele retiro.

Longe da "civilização" e tratado com desvelos carinhosos pela adolescente Clarinha, o padre quebra seus votos de castidade na sombra convidativa das árvores de cacau. Como ocorre com Serge Mouret no Paradou criado por Zola, a natureza agradável da propriedade rural cercada pela floresta amazônica excita a sensualidade do padre, fazendo despertar o seu "temperamento de campônio livre e robusto" (Sousa, 1987, p.210). No entanto, ao contrário de Mouret, o padre Antônio não perdera a memória; servindo-se indiferentemente ora do "senso comum do campônio" (ibidem, p.185), ora de uma "filosofia egoística e chicaneira" (ibidem, p.183), o padre paraense convence-se de que a situação era tolerável e reversível e, por isso, peca voluntária e conscientemente. Mouret, ao contrário, ao recuperar a memória e tornar-se consciente de seu erro, arrepende-se, abandona sua amante Albine e, a despeito de alguma hesitação, retoma suas funções sacerdotais. $\mathrm{O}$ padre Antônio, ao contrário, teme apenas que um eventual escândalo prejudique a sua carreira. Quando descobre que os relatos fantasiosos de Macário criaram-lhe em Silves uma santa reputação de missionário audaz, resolve voltar à sua paróquia acompanhado de Clarinha, a quem convenientemente instalaria em sítio afastado da cidade para poder desfrutá-la com discrição. Nesse particular, o padre Antônio lembra os padres cínicos de Eça de Queirós.

Inglês de Sousa é superior a Marques de Carvalho, pois cria personagens ricas como o sacristão Macário, que, posto ao lado do quixotesco "missionário da Mundurucânia", torna-se uma espécie de Sancho Pança paraense. Sousa narra sua história com um tom irônico que não poupa nem mesmo o anticlerical Chico Fidêncio, medíocre portador das ideias modernas de então. Consegue realizar, enfim, uma representação bem abrangente de uma típica povoação amazonense com toda a sua complexidade política e social. Entretanto, assim como Carvalho, Sousa incide na visão ne- 
gativa do mestiço, visto como uma tentação e uma ameaça por sua sensualidade. Clarinha, que possuía uma "linda boca vermelha de lábios fortes e carnudos" (ibidem, p.195), portava o "cheiro afrodisíaco das mulatas paraenses" (ibidem, p.192) que pôs a perder um padre idealista.

Também mestiço é o protagonista de O cromo, romance de Horácio de Carvalho. Dr. Teixeira, porém, é uma espécie de herói naturalista, que se conservou casto até os 33 anos para poder dedicar-se integralmente à ciência. Médico do interior de São Paulo, passa a tratar Ester, filha de um rico cafeicultor. A jovem padece com delírios, dores de cabeça e hemorragia. O médico trata-a com hipnose, pois tem a convicção de estar diante de um caso de histeria. Com o êxito do tratamento, Dr. Teixeira conquista o respeito e a amizade de Ester, por quem se apaixona. A moça, no entanto, morria de amores por certo estudante de Direito que vira uma única vez em um baile; o rapaz era loiro, além de possuir olhos azuis e pele clara. A pretexto de assegurar a saúde da filha, o major Cornélio muda-se com toda a família para a cidade de São Paulo, onde depois Ester encontra-se casualmente com o estudante, mas, ao conhecê-lo melhor, decepciona-se com a sua vulgaridade. O caminho fica, portanto, aberto para as investidas do médico, que passa a corresponder-se com Ester.

Ainda no interior, o Dr. Teixeira rende-se, entretanto, aos encantos de Tonica, uma mulata de corpo escultural. Quando já não se sentia com forças para livrar-se da amante, o médico também parte para a capital deixando a clínica aos cuidados de colega recém-formado. Em São Paulo, é muito bem recebido pela família de Ester e tem ocasião de tratar com êxito de sua mãe, D. Eufrásia, que sofria com os males da menopausa. Antes de fazer um pedido de casamento em regra, combina com Ester uma entrevista no gabinete da moça para quando o pai e o irmão dela estivessem ausentes. Chegado o dia do encontro, o médico ministra sonífero à mãe da moça. Depois, à noite, a sós com Ester, hipnotiza-a para conter-lhe a crescente exaltação e para poder apreciar a nudez de seu corpo virgem, que não obstante deixa intacto. Logo depois, o médico faz 
o pedido e celebra-se o casamento. Dr. Teixeira e Ester tornam-se, assim, um modelo higienista de felicidade conjugal. Note-se, entretanto, que o médico respeitou a virgindade da rica herdeira branca, mas não hesitou em relacionar-se sexualmente com a mulata Tonica, companheira de um amigo seu. Ricardo, irmão de Ester, abusa, por sua vez, de criada da família; esta moça, que também era mestiça, engravida. Mais uma vez, representa-se o mestiço como desencadeador e objeto da lascívia do branco.

O cromo é um mau romance, mas é também um belo catálogo de características do Naturalismo brasileiro. Ambos os protagonistas são devotados à ciência; mencionam-se na narrativa autores e obras científicas. O livro contém episódios eróticos como a exibição dos corpos nus de Tonica grávida e de Ester hipnotizada. O narrador não hesita em mencionar saliva, sangue, pus e outras secreções e excreções do corpo humano como as descritas em La terre, de Zola (p.344, 381 e 386), e disserta sobre questões contemporâneas como a campanha abolicionista, o separatismo republicano paulista, a expansão urbana de São Paulo e a vida social dos barões do café. Não há, entretanto, qualquer inter-relação mais evidente entre os problemas políticos e sociais contemporâneos abordados e a vida das personagens. O cromo é um romance típico do Naturalismo brasileiro até mesmo pelo romantismo residual que reponta na caracterização das personagens e nas descrições de paisagens.

Ambientado no interior paulista como $O$ cromo, o romance $A$ carne, de Júlio Ribeiro, também apresenta um par de protagonistas apaixonados pela ciência. Órfã de mãe, Helena (Lenita) recebera uma educação masculina por desejo do pai, que lhe assegurou o estudo de várias ciências e línguas e franqueou-lhe a leitura de todo e qualquer livro. Barbosa, filho de um rico fazendeiro, pudera morar na Europa, onde estudara e convivera com grandes cientistas.

Ao perder o pai, Lenita fica muito abatida e procura recuperar a saúde na fazenda do coronel Barbosa, que fora tutor de seu pai. $\mathrm{Na}$ propriedade rural, a doença agrava-se, mas é miraculosamente curada com apenas uma injeção. O coronel tinha um filho, já maduro, que se encontrava nas longínquas margens do rio Paranapanema, 
onde fora caçar. Lenita ouve falar desse homem, que já fora casado, e passa a idealizá-lo como um refinado cavalheiro. Quando Barbosa volta e apresenta-se diante dela enlameado, com a barba e o cabelo crescidos e com o hálito recendendo a cachaça, a moça decepciona-se profundamente e fica até mesmo indignada porque ele, sem muita conversa, logo se tranca no quarto alegando uma já antiga enxaqueca. No dia seguinte, Barbosa procura-a no pomar com roupas limpas e elegantes e trata-a com distinção e delicadeza. O casal logo inicia uma longa e erudita conversa sobre botânica. Nos dias seguintes, fazem com aparelhos adquiridos por Barbosa experiências de física e química e traduzem trechos de autores latinos.

Quando o relacionamento científico entre os dois ia de vento em popa, Barbosa vê-se obrigado a ir a Santos resolver problemas financeiros do pai. Entristecida com a iminente partida do amigo, Lenita dispõe-se a arrumar-lhe as malas. Ao sentir o cheiro de que o quarto de Barbosa estava impregnado, Lenita sofre um ataque histérico.

De São Paulo, Barbosa envia a Lenita uma longa carta repleta de erudição científica em que disserta sobre a estrada de ferro Santos-Jundiaí, São Paulo, a serra do Mar e o litoral paulista. Somente no final da missiva confessa ter pensado em Lenita.

Quando Barbosa volta, o casal abandona os livros e os aparelhos científicos para dedicar-se às caçadas. Barbosa prepara para Lenita uma ceva no meio da floresta, onde a moça abate vários animais. Entretanto, nesse mesmo lugar, Lenita é picada por uma cascavel. Mesmo socorrida por Barbosa, que suga o lugar atingido para retirar parte do veneno e toma todas as providências necessárias, Lenita teme morrer. Nessa hora extrema, confessa seu amor por Barbosa, que então simplesmente a beija na testa.

Sentindo-se de todo recuperada da ação do veneno, Lenita entra furtivamente no quarto de Barbosa à noite. Inicia-se, a partir de então, uma longa série de encontros amorosos a princípio no quarto de Lenita e, depois, em plena natureza.

Uma nova viagem de Barbosa vem a interromper o idílio. Entediada, Lenita vai ao quarto do amado e, ao mexer em suas gavetas, 
descobre relíquias de antigas conquistas amorosas. Presa de ciúmes retrospectivos e considerando Barbosa um "dom-João de pacotilha”, Lenita sente-se usada. Ao descobrir logo depois que estava grávida, Lenita decide deixar a fazenda para casar-se segundo os preconceitos da sociedade.

Quando retorna à fazenda, Barbosa sente o vazio deixado pela moça e recrimina-se por ter-se apaixonado. Dias depois, Barbosa recebe uma carta de Lenita, em que a moça trata longamente do progresso urbano, social e econômico de São Paulo. Somente no final da carta revela estar grávida e à procura de um casamento de conveniência que proporcionasse ao seu filho um pai socialmente aceitável.

Curiosamente, esse romance naturalista apresenta um final melodramático. Barbosa aplica-se veneno e sua mãe, que havia anos não andava, deixa a cama e arrasta-se até o quarto do filho para presenciar a sua agonia. A carne é um mau romance, pois suas personagens concebidas a priori estão apenas esboçadas e são incoerentes. Lenita, por exemplo, que tão avançada mostrava-se e tão indiferente parecia diante dos preconceitos sociais, entregando-se a um homem separado, descobre no final do romance que não é amor aquele "que não tenda a santificar-se pela constituição da família, pelo casamento legal” (Ribeiro, 1991, p.141).

A despeito disso, A carne é, de todos os romances aqui analisados, o que mais diretamente trata da questão servil. Os escravos são, a princípio, alvo da piedade da Lenita que possui sólida formação humanista e, depois, vítimas do sadismo da Lenita que sofre de histeria. Os escravos são também parte da paisagem natural quando se amam sob as vistas excitadas de Lenita e são parte da realidade econômica quando movem o engenho ou interrompem seu funcionamento ao serem apanhados nas engrenagens. $O$ narrador revela os castigos físicos a que se submetiam os escravos e a justiça sumária que se lhes ministrava com a complacência do fazendeiro, mas trai seu preconceito racial ao atribuir-lhes uma "catinga africana, indefinível, que doía ao olfato" (ibidem, p.64) e uma linguagem que era uma "algaravia bárbara, horripilante, impossível de repro- 
duzir" (ibidem, p.97). O narrador também menciona a "maledicência característica da raça negra” (ibidem, p.137).

Dos romances de 1888, A carne é o que presta o maior tributo a Zola. Júlio Ribeiro dedica o seu livro "ao príncipe do Naturalismo Emílio [sic] Zola", a quem se dirige em carta transcrita com verso emprestado de Dante: "Tu duca, tu signore, tu maestro". Nesse paratexto, Ribeiro pondera que a dedicatória seria provavelmente agradável ao grande escritor: "Pourquoi pas? Les rois, quoique gorgés de richesses, ne dédaignent pas toujours les chétifs cadeaux des pauvres paysans" (ibidem, p.7). Essa homenagem de um brasileiro, datada de 25 de janeiro de 1888, talvez fosse um desagravo ao grande escritor francês, que fora tão asperamente criticado no ano anterior pela publicação do romance La terre. Em A carne, assim como no episódio mais escandaloso de La terre, um touro fecunda uma vaca. Lenita, ao contrário de Françoise, não intervém, mas apenas contempla a cena à distância. Segundo o narrador, Lenita considera o ato fisiológico "grandioso e nobre em sua adorável simplicidade" (ibidem, p.61). Em La terre, Jean contempla a cena impassível porque, simplesmente, "c'était la nature" (Zola, 1999, p.37).

Apesar de proclamar-se discípulo de Zola, Júlio Ribeiro não realiza um estudo satisfatório da questão fundiária e da cultura camponesa como Zola fez em La terre. De todos os romances publicados em 1888, somente Inglês de Sousa segue à risca o exemplo de Zola ao escrever $O$ missionário, que contém uma análise abrangente de uma sociedade provinciana com suas várias classes e tipos sociais, além de discutir questões polêmicas como o celibato dos sacerdotes católicos. Diga-se, entretanto, que nenhum dos romances aqui considerados trata de modo consequente da escravidão, o mais grave problema social do Brasil no final do Império. Em A carne, os escravos fornecem pretextos para evidenciar a histeria de Lenita. Provavelmente, o racismo pseudocientífico, que se revela nas considerações preconceituosas e estereotipadas dos narradores sobre negros e mulatos, vistos como um perigo e uma tentação para os brancos, comprometia uma discussão mais aprofundada da questão servil. 
Como se nota claramente em Uma família baiana, os romances de 1888 ainda trazem fortes marcas queirosianas em determinados episódios, na descrição de espaços e na caracterização e apresentação de personagens, mas já são tributários de Zola na importância atribuída ao temperamento e à fisiologia, na coragem em abordar temas polêmicos como o incesto, no cientificismo e no tratamento franco e ousado da sexualidade. No entanto, nesses romances já se nota a constituição de uma linhagem de personagens nacionais, representada pelas histéricas Ester (O cromo) e Lenita (A carne), prováveis descendentes de Magdá, protagonista do romance $O$ homem, relativo sucesso de público do ano de 1887. 


\section{4 \\ A REPERCUSSÃo DA MORTE DE ZOLA EM PERIÓDICOS BRASILEIROS ${ }^{1}$}

Quando Émile Zola (1840-1902) morreu, o naturalismo brasileiro estava quase exaurido. Júlio Ribeiro (1845-1890), Adolfo Caminha (1867-1897) e Manuel de Oliveira Paiva (1861-1892) já haviam falecido; Inglês de Sousa (1853-1918) e Aluísio Azevedo (1857-1913) já haviam publicado suas últimas obras significativas, respectivamente Contos amazônicos (1893) e Livro de uma sogra (1895). Seguiam em atividade apenas autores de menor expressão como Domingos Olímpio (1850-1906), Antônio Sales (1868-1940) e Rodolfo Teófilo (1853-1932). Publicados em 1902, Canaã, de Graça Aranha (1868-1931), e Os sertões, de Euclides da Cunha (1866-1909), já anunciavam novas experiências estéticas. Entretanto, inúmeros colaboradores e redatores de jornais brasileiros eram admiradores, seguidores ou mesmo adversários do Naturalismo francês. Por isso, a morte de Zola ocorreu em momento propício para sugerir um balanço crítico do Naturalismo e suscitar notícias, artigos e crônicas que contivessem reflexões interessantes sobre sua obra e a validade da estética naturalista.

1 Publicou-se primeira versão deste artigo na revista canadense Excavatio (v. 20, n.1-2, 2005). Brigitte Hervot realizou a tradução do português para o francês. 
A partir desse pressuposto, consultaram-se os periódicos cariocas Cidade do Rio, Jornal do Brasil, O País, Jornal do Comércio, A Notícia, Correio da Manhã e Gazeta de Notícias e o paulistano O Estado de S. Paulo, nos quais se encontraram três tipos de textos motivados pela morte do grande escritor francês: 1) notícias sobre o sinistro que a motivou e sobre as cerimônias e homenagens póstumas, ${ }^{2}$ 2) necrológios sem assinatura e 3) textos de colunistas ou colaboradores regulares.

\section{Necrológios}

No dia 30 de setembro de 1902, somente o jovem Correio da Manhã, fundado em 15 de junho de 1901 por Edmundo Bittencourt (1866-1943), adversário feroz dos governos da Primeira República, e o vetusto e eternamente governista Jornal do Comércio deixaram de publicar artigos em homenagem a Zola. As exceções não ofuscam o fato relevante de que a maioria dos principais jornais brasileiros reconheceu ser necessário pronunciar-se sobre o trágico acontecimento, o que denotava a importância então atribuída ao autor de L'assommoir (1877).

O necrológio da Gazeta de Notícias, o jornal brasileiro que mais dera espaço à literatura no último quartel do século XIX, definia o morto ilustre como um "lutador frequentemente apaixonado" e previa que, juntamente com as homenagens ao grande artista, surgiriam manifestações de "intolerância" e "paixão partidária" porque os que lutaram pela condenação do capitão Alfred Dreyfus, acusado de entregar segredos militares franceses aos inimigos alemães, nunca perdoaram a decisiva e vitoriosa intervenção de Zola pela reabertura do processo com a publicação de "J'accuse", carta aberta ao presidente da República divulgada em L'Aurore, edição do dia 13 de janeiro de 1898. Quanto à obra literária, o articulista

2 Como este ensaio trata apenas de questões literárias, esses textos meramente informativos não são considerados, apesar de serem numerosos. 
notava que em cada livro havia "o aspecto genérico da sociedade, [...] das suas misérias, dos seus vícios e das suas virtudes”. Ressaltava também a convivência em suas páginas "das cenas mais simples da vida trivial" com "cenas verdadeiramente épicas", o que se verificaria, por exemplo, em Germinal (1885) e Fécondité (1899) (Emílio Zola, Gazeta de Notícias, 1902, p.1).

O necrológio do vespertino A Notícia, que contava com colaboradores literários de excelente nível, não foi tão sóbrio quanto o da Gazeta de Notícias. Logo no início, já se apresentava Zola como o "maior romancista francês do século XIX", cuja "primeira e mais propalada ambição" fora fundar o romance naturalista, por ele chamado de "experimental". Não obstante, o articulista relativizou a importância do rótulo, que haveria sido adotado por inclinação polêmica e, também, para testemunhar "admiração e fidelidade às normas da ciência”, que tanto avançara com o método experimental de Claude Bernard (1813-1878). Em termos estritamente romanescos, o objetivo de Zola seria criar "o romance de observação exata que não inventasse personagens estranhos, irreais, inverossímeis". Nesse esforço residiria o grande mérito do escritor, cuja obra "representava uma reação salutar contra os exageros do Romantismo, que criava, a cada momento, tipos de fantasia". Zola, ao contrário, defendia o "exame real da natureza" e considerava a influência do meio sobre os indivíduos, cuidados a que eram indiferentes românticos como Eugène Sue (1804-1857), Ponson du Terrail (1829-1871) e Alexandre Dumas (1802-1870). A despeito dos elogios iniciais, o articulista denunciava como irrealizável o programa do romancista, pois "sobre cada indivíduo pesam [as] mais variadas influências, desde a hereditariedade, até o meio físico. O impossível é prever de antemão, com segurança, qual será a parte de cada uma”.

Não obstante, o articulista de A Notícia justificava a ênfase de Zola no cientificismo pela necessidade de "forçar a mola", ou seja, acentuar suas diferenças em relação ao Romantismo. Na prática, o romancista teria recorrido à imaginação e assim esbatido o "fio científico" de seus livros: a ideia da hereditariedade. Segundo o articulista, as acusações iniciais de que Zola buscava "o imundo 
e o abjeto" dissiparam-se com o tempo; o que o autor de Nana (1880) não admitia era "pintar uma humanidade puríssima - e por isso mesmo falsíssima - onde só existissem tipos ideais, tipos angélicos"; apesar disso, o romancista teria sido comedido ao narrar "cenas de volúpia". O artigo encerrou-se com uma referência à participação de Zola no caso Dreyfus, classificando a publicação de "J'accuse!" como "um ato de coragem superior a todos os elogios" (Emílio Zola, A Notícia, 1902, p.1).

No jornal $O$ Estado de S. Paulo, a única folha provinciana consultada, foi publicado necrológio em que se mencionou a divisão na opinião pública sobre Zola. Em um extremo, colocavam-se seus admiradores incondicionais, que o consideravam o maior escritor do século XIX; no outro, encontravam-se seus detratores, que o acusavam de sobreviver à custa de golpes de publicidade. $\mathrm{O}$ articulista considerava-se em condições ideais para pronunciar-se com isenção sobre o romancista porque já não se ouviriam então nem mesmo os "derradeiros ecos" das polêmicas desencadeadas pelo ciclo dos Rougon-Macquart e porque as então recentes polêmicas do caso Dreyfus não tinham repercutido no Brasil. Comparada à de Victor Hugo (1802-1885), a obra de Zola não seria tão "brilhante", mas podia ser considerada mais "conscienciosa" por seu caráter metódico e regular. Equiparando-se ao autor de Os miseráveis (1862), Zola teria obtido fama universal graças ao ciclo dos Rougon-Macquart e a sua habilidade em autopromover-se:

Não o caluniam talvez os que ouvem gritos de anunciante confundidos com os brados de revolta do chefe do Naturalismo contra os românticos [...] e com os rugidos do leão generoso que, inesperadamente, surgiu ao lado de Dreyfus, a estender as garras contra o estado-maior do exército e contra os jesuítas, dominadores ocultos da política republicana, que já por diversas vezes o indignara. (Emílio Zola, O Estado de S. Paulo, 1902, p.1)

Após considerações sobre o historiador dos Rougon-Macquart e o simbolista de Os quatro evangelhos, o articulista assim manifestou-se: 
Há uma grande parte da vastíssima obra de Zola que nos repugna. Há outra que nos seduz. E sinceramente lamentamos, sem pruderie, que, talvez por um capricho ou por um desvario de moço, tanto tempo andasse pela lama e pela sombra, acabrunhado, mórbido, inimigo da alegria, quem nos parece que nasceu para andar sempre pela estrada larga e limpa, ao sol. (ibidem)

O articulista afirmava preferir o épico do romance La débâcle (1892) ao cronista de costumes de Nana, criticava a irregularidade estética de sua produção e lamentava que em Germinal Zola se esterilizasse apregoando conhecimentos de fisiologia que seriam afinal contestáveis. No entanto, colocou-o, ao lado de Balzac (17991850), em posição de destaque na plêiade dos realistas do século XIX (ibidem).

O País, influente matutino dirigido pelo republicano histórico Quintino Bocaiúva (1836-1912), ex-senador e ex-governador do estado do Rio de Janeiro, decidiu enfatizar o ânimo combativo do "grande atleta da pena" [sic], a sua inalterável disposição de lutar contra "os pontífices do erro e da rotina", ou seja, contra o tradicionalismo intelectual. Sua primeira batalha teria sido em defesa do pintor impressionista Édouard Manet (1832-1883) contra o academicismo. Depois da publicação de Nana, fora obrigado a defender sua obra e o Naturalismo dos "dardos de uma crítica inclemente, cheia de injúrias e covardias” (Emílio Zola, O País, 1902, p.1).

Se na França Zola necessitava enfrentar contestações, seus editores em outros países expunham-se ao dissabor ainda maior de responder a processos judiciais. Segundo o articulista de $O$ País, tamanha oposição ocorreu porque "em toda a parte a verdade aflige e atormenta, morde as consciências hipócritas, fere os prejuízos necessários à exploração de todos pelo agrupamento dos convencionais".

A trilogia das Três cidades marcaria o início de uma nova fase, pois subitamente o romancista transformara-se no "sacerdote da justiça e da verdade, surgindo admirável de potestade espiritual". Ouve-se então "o grito J'accuse", que "ecoou pelo universo como 
uma voz nova de justiça" e com o qual se iniciava "uma das maiores epopeias" de todos os tempos (ibidem).

O Jornal do Brasil preferiu narrar os percalços iniciais enfrentados por Zola desde sua adolescência modesta até alcançar o sucesso literário com a série dos Rougon-Macquart, que dele fez o principal escritor naturalista. Ao conceber a obra literária como "a natureza vista através de um temperamento" ou "um resumo da natureza feito pela imaginação", Zola teria, segundo o articulista, resumido o programa da nova escola. Em suas últimas obras, o romancista manifestaria propensão ao idealismo, ao "espírito das sínteses gigantescas, abrangendo a França e o Universo”. Dessas sínteses, algumas seriam "falsas", porém todas "sinceras". Após essa pequena restrição, o articulista restabeleceu o tom laudatório próprio dos necrológios.

Ponhamos de parte o que possa haver de heterodoxo e iconoclasta na obra do romancista. [...] Verdade! é o título do seu último livro; verdade é a aspiração da sua vida inteira. E verdade para quê? Para que a justiça, enfim, triunfante, distribua mais equitativamente a riqueza, corrija a plutocracia ávida, distribua o pão pelos que o cultivam e regam com o seu suor, aqueça a mansarda do proletário... (Emílio Zola, Jornal do Brasil, 1902, p.1)

É bastante significativo esse fragmento que fazia de Zola uma espécie de paladino da justiça social, pois o Jornal do Brasil, quando de seu relançamento em 15 de novembro de 1894, ${ }^{3}$ apresentou-se como "defensor dos pequenos e dos oprimidos" (cf. Sodré, 1966, p.304). O artigo também exaltou a "abnegação" com que o escritor lutava pelas boas causas e de que era exemplo recente sua participação corajosa no caso Dreyfus. Já no "declinar da vida”, "coberto de glória e nadando em ouro", Zola "tudo jogou: renome, descanso, posteridade, em favor de um mísero condenado [...] e jamais o

3 O Jornal do Brasil circulara anteriormente de 1891 a 1893, quando sofreu perseguições por apoiar a Revolta da Armada. 
prestígio da inteligência ao serviço da verdade e da justiça foi mais imperioso e decisivo" (Emílio Zola, Jornal do Brasil, 1902, p.1).

De todos, o necrológio do vespertino Cidade do Rio, dirigido pelo boêmio, desabusado e imprevidente jornalista José do Patrocínio (1854-1905), que se consagrara nas lutas pela libertação dos escravos, foi o mais crítico; pode-se até mesmo julgar que seu início aludia ironicamente ao teor encomiástico dos textos publicados nos matutinos: "A hipocrisia literária vestiu-se de luto fechado, como símbolo da dor profunda que lhe causou a morte de Emílio Zola". $\mathrm{O}$ articulista desconfiava da sinceridade das pesarosas manifestações de quem não podia avaliar a perda sofrida pelo "moderno espírito francês", uma vez que "Zola não era acessível à universalidade das inteligências" e, portanto, não seria devidamente compreendido: "Não era a originalidade de sua missão estética que prendia a maioria dos que lhe decoraram o nome; era o escabroso, o cru, o natural a que obrigava os seus personagens, quando os punha em ação” (Zola, Cidade do Rio, 1902, p.1).

Analisando "filosoficamente" a obra de Zola, o articulista concluiu que "ela tendia a matar o capitalismo e abrir caminho [...] ao direito à equidade para com o operário”. A tal observação, que valia por um elogio, logo se seguiu uma violenta crítica ao ativismo político do escritor, que se voltara contra as congregações religiosas: "Com uma obstinação irritante, Zola combatia a moral cristã, procurando derrocar o único alicerce que pode manter de pé o progresso humano: a fé católica. Não pregava a esperança, mas o desalento" (ibidem).

O articulista comparou Zola às "secreções mórbidas do organismo", pois, do mesmo modo como estas afetam a saúde do organismo e impedem a plena absorção dos alimentos, "erros filosóficos e religiosos" como os do escritor francês impediriam a expansão de Deus no "mundo espiritual". Mas a solução não se faria esperar:

A morte, a grande purificadora, incumbe-se então de remover o foco de infecção intelectual e pouco a pouco o mundo readquire a sua vida normal de crença e de esperança no Supremo Ser, que é 
a sua força e a sua beleza, do mesmo modo que o organismo adoentado readquire a vida, removida a causa que o depauperava e amarelecia. (ibidem)

Ironicamente, a Cidade do Rio, que vislumbrava os efeitos "benéficos" do desaparecimento do escritor francês, também encontraria a "morte" naquele ano de 1902, em que deixaria de circular.

Após conclamar o leitor a combater a "incredulidade", o articulista do jornal de Patrocínio assegurou que os adversários de Deus sempre apresentariam uma falha na armadura - assim como Zola, que "nunca foi verdadeiramente assimilado" e a quem os próprios discípulos haviam abandonado. $\mathrm{O}$ artigo encerrou-se com uma súplica a Deus para que Zola recebesse "nova missão" (nova encarnação?) a fim de que sua "poderosa espiritualidade" pudesse, então, ser "fonte de resignação e esperança" (ibidem).

\section{Artigos e crônicas}

No dia primeiro de outubro de 1902, Medeiros e Albuquerque (1867-1934), crítico literário de A Notícia que se ocultava sob o pseudônimo J. dos Santos, manifestou-se sobre a morte de Zola, em cuja obra distinguia duas partes até certo ponto incompatíveis. O crítico "exigia [...] o impossível, quando pedia que a literatura se fizesse científica e experimental"; o romancista, no entanto, "corrigia na prática esses exageros". Na realidade, Zola protestava contra as "inverosimilhanças do Romantismo", de que seria exemplo o indianismo brasileiro, e propunha o "romance possível, o romance provável, em que nada houvesse a contrariar os fatos de cada dia". A preocupação com a exatidão documental teria sido responsável pelo escândalo desencadeado pela personagem Jesus Cristo em A terra (1887); esse nome fora adotado apenas por ser atribuído na França a "bêbados de gênio alegre e folgazão", sem, portanto, qualquer propósito de ofender a religião cristã. J. dos Santos encerrou sua coluna assinalando uma clara opção de Zola em suas últimas obras 
pelo romance de tese, destinado à "proclamação das grandes reivindicações sociais” (Santos, 1902, p.3).

José Veríssimo (1857-1916), um dos principais críticos brasileiros, pronunciou-se sobre a morte de Zola em artigo publicado no Correio da Manhã do dia 3 de outubro de 1902. No autor de Germinal, o crítico reconhecia um acentuado orgulho profissional e uma aguda consciência de sua função. Após o desastre de Sedan, o romancista encarregar-se-ia de expressar o "sentimento do real" que, entre os franceses, surgira do "horror do presente" e do "desconsolo do passado", causados pelo remorso de terem apoiado ou suportado o Segundo Império. Como criador da literatura experimental, Zola inspirara-se em Balzac e fora influenciado pelas doutrinas de Renan (1823-1892), Taine (1828-1893) e Claude Bernard. No entanto, haveria conservado em sua obra, a despeito de seus livros de crítica e artigos polêmicos, certo romantismo, que se manifestaria de modo pleno no simbolismo das séries Três cidades e Quatro evangelhos.

Como, segundo Veríssimo, a epopeia foi sempre uma "forma literária sociológica”, a série dos Rougon-Macquart revelou, com sua “acentuada feição sociológica”, o gênio épico de Zola, isto é,

... a sua capacidade de animar o inanimado, de agitar e mover as massas, o seu dom de antropomorfismo e de representação; e seu gosto da alegoria e do símbolo, com a sua preocupação, primeiro só de artista, mas logo depois de homem, pela vida em toda sua complexidade e interesse, e a sua simpatia pela dor humana, acabaram por dar-lhe na literatura francesa, e excedendo-a, na literatura universal um lugar como só o teve Victor Hugo, e como só o tem neste momento Tolstói. (Veríssimo, 1902, p.1)

A obra de Zola seria naquela ocasião "o mais forte documento da confiança dos homens emancipados no futuro da humanidade, regenerada pela ciência, isto é, pela verdade e pela justiça". O romancista haveria iluminado com um "largo clarão de benevolência" ou um "raio de esperança" os "antros lôbregos que a sociedade cria aos miseráveis na taberna, na mina, no mercado, no teatro, no 
mundo". A "sentida piedade humana" de Zola teria resultado do contato dos miseráveis mais do que da influência socialista que se lhe fez sentir nos últimos anos.

Veríssimo encerrou seu artigo notando que, naquele momento, todos os grandes escritores e artistas seriam socialistas e voltar-se-iam para os problemas sociais. Zola seria o "mais nobre representante" dessa tendência (ibidem).

Armando Erse (1875-1950), que semanalmente ocupava, sob o pseudônimo de João Luso, o rodapé do Jornal do Comércio com suas "Dominicais", enfatizou em longo artigo publicado no dia 5 de outubro de 1902 o contínuo combate da imprensa à obra de Zola. Desde as primeiras produções do escritor, a crítica francesa "guerreou-o, excomungou-o em termos os mais intolerantes e pontificais”, quando não agiu de má-fé.

Sucedendo aos velhos mestres do Naturalismo, mas dando à doutrina que abraçava uma extensão e uma intensidade que a sua pena era a primeira a patrocinar, a sua obra foi julgada de puro escândalo e como tal odiosamente repelida. Do que nele dizia amor à verdade, a crítica teimava em só enxergar amor à notoriedade. (Luso, 1902, p.1)

Enquanto se mantivera no campo literário, Zola restringira, de certa maneira, a divulgação da "Verdade, de que era apóstolo"; correspondentemente, a reação dos desafetos era, até certo ponto, ainda moderada.

Ficava [a Verdade] nos livros, era literatura; não se atrevesse ela a sair do gabinete do escritor para, em vez de tomar o caminho de uma livraria, vir à face dos representantes da sociedade, desmascará-los, acusá-los, pedir-lhes contas, ante o mundo inteiro, dos abusos sancionados e dos crimes praticados... (ibidem)

Com a publicação de "J'accuse", porém, o cidadão Zola expôs-se a sofrer os mais violentos ataques, pois "os jornais, que não lhe 
respeitaram a alevantada inspiração, assacaram-lhe as piores injúrias, atribuíram-lhe todas as desonestidades, todas as venalidades". O autor de Vérité (1903) triunfara em sua defesa de Dreyfus, mas suscitara ressentimentos que, naquele momento, levavam os jornais de direita L'Eclair, L'Intransigent e La Libre Parole a protestar contra as homenagens póstumas a ele dedicadas (ibidem).

No mesmo domingo, Olavo Bilac dedicou a Zola a crônica semanal que publicava na Gazeta de Notícias. O poeta brasileiro exaltou a tenacidade e o método com que o romancista francês consagrava-se à sua profissão, que lhe tomava oito horas de trabalho diário.

Bilac admitiu que poderia parecer ingenuidade de Zola almejar "endireitar as cousas do mundo" com a literatura, mas, na realidade, o "apóstolo da verdade e da justiça" nunca se enganara sobre a "incurabilidade da nossa miséria". Pretendia apenas atender a um imperativo de consciência ao colocar "sua bondade e o seu talento no serviço dessas duas grandes ideias da Justiça e da Verdade, aspirações intangíveis da alma humana” (Bilac, 1902, p.1).

Em suas campanhas, Zola teria sofrido "a guerra dos interesses feridos, a revolta da hipocrisia desmascarada, a vingança da maldade acuada nas trevas". Contra o romancista, haveriam atirado inúmeras injúrias:

Ela era o explorador da bestialidade humana, o remexedor dos mais ignóbeis detritos da vida, transformando a arte em servidora dos mais baixos instintos da plebe, profanando a vida, rebaixando o amor, amaldiçoando Deus, amassando com a lama dos alcouces os livros que pervertiam a humanidade... (ibidem)

Indiferente aos murmúrios, Zola seguiria erguendo seu edifício que, embora lançasse seus fundamentos "no fundo asqueroso do pântano humano", "demandava o céu, a claridade serena, a alta glória da luz”. O último projeto do romancista, a série dos Quatro evangelhos, coroaria a sua obra com os "quatro ideais da regeneração da espécie: a fecundidade que santifica o amor, o trabalho que anula a miséria, a verdade que emancipa a razão, a justiça que gera a bondade..." (ibidem). 
Bilac encerrou sua crônica lembrando que a imitação de Zola criara uma "multidão de pornógrafos" que já teria desaparecido ou desapareceria em breve. O mestre, ao contrário, sobreviveria para sempre como uma "glória da espécie humana" (ibidem).

Na mesma edição em que o poeta brasileiro exaltava Zola, outro colaborador da Gazeta de Notícias desafinaria o coro de elogios. Em seus "Rabiscos", Oliveira e Silva revelou-se pessoalmente atingido por dois adjetivos que a crítica brasileira havia atribuído aos detratores de Zola: hipócritas e interesseiros. Por formar-se com o auxílio dos "mestres do pensamento", cujos nomes não declinou, Oliveira e Silva declarou-se habilitado a perceber "o erro das modernas correntes intelectuais" e acusou a crítica brasileira de não poder "julgar da sinceridade das opiniões" dos que combatiam o romancista e sua escola por ignorar inteiramente "a natureza e o valor de semelhantes opiniões” (Silva, 1902, p.2).

Assumindo um ponto de vista religioso, o articulista considerou mais insuportável a "intransigência pelas supostas verdades ditas por um homem" do que a que se exige para as "verdadeiras verdades" [sic] que seu Deus havia revelado. Insinuou também serem fanáticos "os terríveis admiradores do tipo mais acentuado de todas as negações”, Zola.

O que mais irritou Oliveira e Silva nas homenagens ao romancista francês foi o epíteto de "Apóstolo da Verdade" que se lhe atribuiu. Para ele, "a maior das verdades, aquela de que decorrem todas as outras como corolários necessários, é a existência de Deus e a sua providência" (ibidem). Sem Deus, não haveria verdade "de espécie alguma”. Como Zola era ateu, o articulista questionou de que verdade o romancista francês poderia ser o apóstolo.

Considerou, inicialmente, o "suposto amor" de Zola pelas massas. Reconheceu que a obra-prima Germinal é um "quadro assombroso da grande questão do século, a luta entre o capital e o trabalho", mas ponderou que "entre uma tela e a solução de um problema" haveria "muita diferença". Segundo Oliveira e Silva, o escritor equivocava-se em sua defesa do socialismo por filiar-se à vertente materialista do movimento. 
Ademais, o articulista declarou-se cético quanto ao "apostolado" de Zola em favor dos "proletários que gemem sob a pressão do capital", posto que o romancista seria ele mesmo um "opulento capitalista".

Embora reconhecesse que Zola possuía a capacidade de "apanhar as faces ridículas ou criminosas da sociedade em que vivia”, Oliveira e Silva contestava também a opinião de que ele houvesse traçado "um quadro fiel do mundo moderno", uma vez que havia ignorado a "caridade cristã", "legítimo elemento de civilização moderna" que a França possuía e difundia pelo mundo com seus duzentos mil religiosos, apóstolos na verdadeira acepção da palavra.

Aludindo ao romance A terra, acusou Zola de nutrir ódio a Jesus Cristo por dar este nome a "um de seus mais imundos personagens". Quem cometera tal desacato não poderia aceitar a declaração de Jesus: "eu sou a verdade". Segundo o sofisma de Oliveira e Silva, afirmar que Zola seria o "apóstolo da verdade" equivaleria a negar que Jesus fosse a verdade.

Após condenar a presença do "detalhe pornográfico" nas "páginas admiráveis" do romancista, o articulista formulou enfim uma objeção pertinente:

$\mathrm{Na}$ estreiteza de suas vistas, ele não sabia ver o fundo dos caracteres através das paixões. Seu olhar não conseguia penetrar o vício, para nos dar a verdadeira personalidade de seus personagens.

Não conhecia almas, só conhecia temperamentos. (ibidem)

No final de seu artigo, Oliveira e Silva afirmou que Zola foi uma "blasfêmia constante contra tudo quanto de nobre, de casto e de santo as crenças geram nas almas eleitas do Senhor" e assegurou que apenas um serviço haveria prestado: "o Naturalismo no romance, em suas mãos, chegou ao último ponto da degradação; de podre está definitivamente morto" (ibidem).

Em artigo publicado no dia 6 de outubro de 1902, Artur Azevedo dividiu a obra de Zola em três fases. A primeira seria dedicada ao periodismo e à publicação de Les mystères de Marseille (1867), a se- 
gunda corresponderia à série dos Rougon-Macquart e, finalmente, a terceira caracterizar-se-ia pela "moral elevada", que dele fez "um apóstolo quase divino da verdade e da justiça, um elemento vivo de civilização e progresso".

Desse artigo, o mais interessante seria, no entanto, uma menção às circunstâncias misteriosas da morte do romancista. $\mathrm{O}$ dramaturgo e crítico teatral Artur Azevedo reproduziu um suposto diálogo que teria mantido com um amigo que, considerando a perda da Legião de Honra um primeiro atentado contra quem havia atacado os jesuítas em Rome (1896), insinuou haver sido Zola vítima de uma vingança, pois haveria muitos franceses indispostos contra ele: - "Zola não saía de sua terra para munir-se de 'documentos humanos', e ninguém há que goste de ouvir as verdades quando lhe são pessoalmente desagradáveis" (Azevedo, 1902, p.1).

\section{Balanço}

O tom apocalíptico de Oliveira e Silva, que fez de Zola uma espécie de Anticristo, evocava, em certa medida, a polêmica desencadeada no Brasil pela publicação de O primo Basílio (1878), de Eça de Queiroz. Naquela ocasião, Machado de Assis condenava no romancista português, que considerava discípulo de Zola, a "ênfase na sensação física", que resultava no erotismo difuso de suas obras, e o "carinho minucioso" consagrado ao "escuso" e ao "torpe".

Apesar das diatribes de Oliveira e Silva, do alívio manifestado pela Cidade do Rio com a morte do adversário do catolicismo e da menção no necrológio de $O$ Estado de $S$. Paulo à repugnância provocada por parte de sua obra, Zola recebia, no início do século XX, as homenagens devidas a um grande escritor, em quem se reconhecia dedicação profissional, capacidade de crítica social, gênio épico e interesse sincero pelos problemas sociais de seu tempo. Reconhecia-se também a ação renovadora de sua campanha contra o Romantismo e admirava-se a coragem com que se entregara desinteressadamente à defesa de Dreyfus. O que se nota, no entanto, é que então já não 
se aceitavam passivamente os pressupostos do romance experimental, que se considerava meta inatingível, pedra de escândalo e mero preito acrítico à ciência. Formulavam-se, inclusive, críticas à irregularidade estética da sua obra, à sua obsessão pela fisiologia e à sua indiferença pela dimensão psicológica das personagens. Também se acusava o escritor francês de envolver-se em polêmicas apenas com o objetivo de promover sua obra.

Os textos aqui analisados indicavam que o recente envolvimento de Zola no caso Dreyfus e suas últimas produções reforçaram a percepção de seu interesse sincero pelas questões político-sociais, que o levava a desafiar instituições poderosas como o Exército e a Igreja. Num âmbito mais estritamente estético, a publicação das séries Três cidades e Quatro evangelhos, em que se apontavam características simbolistas, suscitou uma releitura do ciclo dos Rougon-Macquart, em que se distinguiram então resquícios românticos. 


\section{5 \\ LITERATURA PARADIDÁTICA E nacionalismo na Primeira República ${ }^{1}$}

\section{Novos tempos, novas lições}

Em A educação nacional, obra publicada em 1890, quando se iniciava o regime republicano, José Veríssimo mostrava-se preocupado com a falta de "orgulho nacional" dos brasileiros que, para fazer frente aos "grandes homens" e às "grandes obras" de outras nações, somente podiam contar com a rica natureza do país. Como um dos principais obstáculos à afirmação do "brasileirismo", o crítico mencionou o "bairrismo" das várias regiões, resultante do isolamento geográfico e da legislação colonial portuguesa, que não estimulava as relações entre as províncias e fazia-as dependentes do Reino. Podendo atuar em favor da "integração do espírito nacional", a instrução pública estava, no entanto, "pessimamente organizada" e não se voltava ao conhecimento do Brasil ou até mesmo das suas regiões. Para agravar esse quadro, crianças e jovens iam estudar no exterior "na idade justamente em que se começa a formar o caráter e o coração” (Veríssimo, 1985, p.45-7).

1 Este ensaio foi originalmente publicado em italiano no número inaugural da revista Kripton, editada por Roma Tre Press. Dedica-se esta republicação a Letizia Zini Antunes, tradutora do artigo, e Giorgio de Marchis, editor do citado periódico. 
Para demonstrar o quanto a educação pública poderia fazer pela "regeneração nacional”, Veríssimo avançou os exemplos da Itália, cuja unificação havia sido obra "dos seus escritores, dos seus poetas, dos seus publicistas, dos seus oradores, dos seus professores" (ibidem, p.50), e da França, que, "diminuída no seu território e fundamente ferida no seu orgulho" com a derrota de Sedan, investia decisivamente em educação:

A literatura pedagógica, até então em França pouco menos de nula, desenvolveu-se em proporções extraordinárias e multiplicaram-se a encherem bibliotecas os trabalhos teóricos e os trabalhos práticos, os trabalhos filosóficos e os trabalhos históricos, sobre as várias feições da ciência e da arte de educar. (ibidem, p.50-1)

No Brasil, onde, ao contrário, nada se fazia, a educação da "mocidade" ficava a cargo de escritores estrangeiros traduzidos, adaptados ou "servilmente imitados". O próprio Veríssimo pôde testemunhar a respeito, confessando que recebera a "primeira instrução" em livros "portugueses e absolutamente alheios ao Brasil". Por isso, acabou por declarar que, no imperativo movimento geral de melhoria da educação nacional, que se esperava do novo regime, era fundamental reformar o "livro de leitura": "Cumpre que ele seja brasileiro, não só feito por brasileiro, que não é o mais importante, mas brasileiro pelos assuntos, pelo espírito, pelos autores trasladados, pelos poetas reproduzidos e pelo sentimento nacional que o anime" (ibidem, p.55).

Antes que surgissem os novos livros didáticos, adequados ao novo regime, as escolas brasileiras seriam tomadas, a partir de 1891, pelo Cuore, de Edmondo de Amicis, em tradução de João Ribeiro. Em 1916, Monteiro Lobato, que alguns anos depois revolucionaria a literatura infantil brasileira com A menina do narizinho arrebitado (1920), concebido como "livro de leitura", ainda julgaria o livro de Amicis digno de ser lido por seus filhos, apesar de ser "tendente a formar italianinhos" (Lobato, 1972, p.246).

De 1894 a 1919, ocorreria finalmente no Brasil um boom de obras destinadas às crianças escritas por Olavo Bilac, Coelho Neto, 
Figueiredo Pimentel, Júlia Lopes de Almeida, Adelina Lopes Vieira, Manuel Bonfim, Zalina Rolim, João Köpke, Arnaldo Barreto, Presciliana D. de Almeida, conde de Afonso Celso, Virgílio Cardoso de Oliveira, João Viana de Almeida, Osório Duque-Estrada, Rocha Pombo, Afrânio Peixoto e Tales de Andrade, entre outros.

Seguindo as diretrizes traçadas por Veríssimo, esses autores didáticos e paradidáticos procuraram contribuir para a "integração do espírito nacional" combatendo as tendências desagregadoras representadas pelo separatismo regional, a imigração indiscriminada e o imperialismo das grandes potências. Obras representativas e bem-sucedidas dessa produção são os Contos pátrios (1894), de Olavo Bilac e Coelho Neto, Porque me ufano do meu país (1900), do conde de Afonso Celso, e A pátria brasileira (1909), de Coelho Neto e Olavo Bilac. Na análise dessas obras, importa considerar os recursos empregados pelos autores para esconjurar os perigos que ameaçavam a jovem República brasileira mediante a formação de "brasileirinhos".

\section{Perigos reais e imaginários}

Instaurada por um golpe de Estado em 1889, a República brasileira passaria por muitos sobressaltos na década de 1890. Em 1890 e 1891, a economia do país foi fortemente abalada pelo Encilhamento, processo fracassado de estímulo a investimentos produtivos por meio de incremento do meio circulante e ampliação do crédito. Em 3 de novembro de 1891, o presidente Deodoro da Fonseca fechou o Congresso, que lhe fazia oposição cerrada, mas vinte dias depois se viu obrigado a renunciar em favor de Floriano Peixoto, vice-presidente, em função da resistência de políticos e militares. Em 4 de fevereiro de 1893, estourou no Rio Grande do Sul uma guerra civil pelo controle do governo estadual e, em 6 de setembro, iniciou-se na baía da Guanabara uma revolução liderada pela marinha de guerra. No final desse mesmo ano, navios da Armada uniram-se 
aos revolucionários do sul do país, do que resultou a organização de um governo revolucionário em Santa Catarina. A vitória definitiva do governo legal ocorreria somente em 23 de agosto de 1895, com anistia geral. Nos anos de 1896 e 1897, o país receberia estarrecido notícias de um levante popular no sertão nordestino. Camponeses liderados pelo fanático Antônio Conselheiro lutariam com admirável bravura e somente seriam derrotados pela absoluta superioridade da quarta expedição militar que marchou contra eles em outubro de 1897. Como se vê, a República, logo em seus primeiros anos, quase pôs a perder a unidade territorial e política que herdara do Império.

A política de estímulo à imigração como forma de substituir o trabalho escravo e de povoar o interior do país veio a constituir, principalmente no sul, comunidades inteiras de imigrantes que não falavam português e não se integravam à cultura brasileira. Tal situação inquietava muitos intelectuais que, no começo do século XX, já mencionavam abertamente o "perigo estrangeiro". Olavo Bilac, por exemplo, que em suas crônicas reivindicava insistentemente do poder público a abertura de estabelecimentos de ensino primário por todo o país, via com bastante apreensão o funcionamento regular de escolas de imigrantes em que se utilizavam línguas estrangeiras, principalmente o alemão. ${ }^{2}$ Tal fato fazia o poeta temer o futuro:

A conquista [do Brasil], se um dia se fizesse, far-se-ia pela absorção pacífica e lenta da nacionalidade brasileira. Levantar-se-ia o povo para repeli-la? Mas como, se já não houvesse povo brasileiro? - Isto é, se a maioria da população do Sul fosse uma gente falando alemão, escrevendo alemão, não falando, nem escrevendo, nem compreendendo o português? (B., 1905, p.2)

Compartilhava essa preocupação Sílvio Romero, um dos intelectuais brasileiros mais respeitados (ou temidos) daquele tempo.

2 A propósito dos estabelecimentos de ensino mantidos por imigrantes, v. Kreutz (2004). 
No opúsculo O alemanismo no sul do Brasil, publicado em 1906, denunciou a voracidade do império germânico, que no curto período de 1884 a 1888, transformou-se na "terceira potência colonial do mundo" (Romero, 1979, p.234), e alertou para o risco iminente que corria o Brasil diante dos projetos de conquista dos alemães:

Para eles, para esses homens que sabem o que querem, o critério supremo da nacionalidade, o sinal revelador, o expoente excelso da raça é a língua, ouçam bem, é a língua. Este sinal é tudo. Onde é a pátria alemã?, perguntava o poeta, e ele mesmo respondia: É onde se fala a língua alemã...

Entre nós, a linguagem é apenas um instrumento para retóricas e parlapatices; não tem outro préstimo, e tanto não tem, e aqui chego ao ponto onde queria aportar, que nas colônias alemãs do Brasil não se fala português... Proh pudor! Fala-se nelas alemão. É dizer tudo; não precisa juntar mais nada para quem compreende a gravidade do fato. (ibidem, p.235)

Assegurando que a doutrina de Monroe era o único obstáculo às pretensões dos alemães no sul do Brasil, pois os fazia temer "uma complicação provável com os Estados Unidos”, Sílvio Romero considerava entretanto inevitável uma tentativa de separação:

Pois pode lá nunca a Alemanha, que conta com a prolificidade de sua gente, com o vigor de seus filhos e com a habilidade deles, admitir que um, ou dois, ou três milhões de germânicos, colocados nos nossos Estados do sul se deixem governar, dirigir, pelos mulatos (é como eles nos chamam a todos) do Brasil?

É mister não saber nada de Alemanha e alemães para acreditá-lo. O Deutschtum do Brasil fará da sè; o da Europa tem confiança e espera. (ibidem, p.255)

Como julgava que o Brasil não podia contar para sempre com o amparo norte-americano, Romero propunha medidas administrativas, políticas e militares para evitar a concentração de alemães em ter- 
ritório contínuo e, entre várias propostas de combate ao Deutschtum (alemanismo), sugeria "forçar os colonos a aprenderem o português, multiplicando entre eles as escolas primárias e secundárias, munidas dos melhores mestres e dos mais seguros processos" (ibidem, p.258).

Bilac também recomendava a abertura de escolas públicas nas colônias como forma de combater o "perigo estrangeiro" e, como autor de manuais escolares, muito provavelmente procurava fomentar o amor ao Brasil entre os filhos dos imigrantes.

Em artigo publicado no Jornal do Comércio em 1912, Alberto Torres já demonstrava possuir argumentos contra o racismo que dava sustentação à ideologia colonialista, especialmente em sua versão germânica:

A ambição ao domínio universal, das raças teutônicas, fundada na pretensão da sua superioridade, é um ideal político conhecido, que conta em seu serviço com a autoridade de uma ciência e de uma literatura, com a força econômica, o poder militar, a aparente superioridade, física e mental, a real vantagem atual, destas raças. É uma pretensão infundada e injusta; e a todas as razões com que a ciência contemporânea respondeu à ciência dos imperialistas, o Brasil - museu vivo de etnologia e esplêndido laboratório de experimentação étnica - pode juntar documentos irrefutáveis. O teutão, localizado no Brasil, prospera ou declina, em função do meio físico ou da vida social, nas mesmas condições que o branco de origem europeia meridional, o preto e o índio. (Torres, 1978, p.258)

Se, por um lado, já não temia a desigual competição do brasileiro com uma suposta "raça superior", o publicista denunciava, por outro, a real ameaça que pairava sobre o Brasil:

... talhado em vastas zonas de influência estrangeira, onde quase todas as estradas de ferro, incluindo as mais rendosas, caem em poder de sindicatos estrangeiros, onde se projeta executar uma rede ferroviária continental, subordinada a planos estranhos aos interesses do país, com a posse de portos, de outros instrumentos 
de viação, obras e serviços públicos, largas feitorias de mineração, agrícolas e pastoris, bastantes estas para aniquilar a indústria nacional, realizando-se, assim, pública e confessadamente, um plano de expansão colonial, uma política social e econômica, um Estado no Estado - e um Estado que traz para a luta com os nossos Estados de politiquice e com a nossa Federação de caudilhagem, com o próprio esqueleto das nossas melhores riquezas, a musculatura da vontade implacável de povos habituados a vencer e o nervo de quantos capitais queiram pedir às Bolsas congestas da Europa! (ibidem, p.120)

Evidentemente, o objetivo maior de Torres era suscitar contra essa ameaça de dominação estrangeira uma reação nacionalista, que em um país novo como o Brasil somente poderia ser liderada pela intelectualidade:

... a formação artificial das nacionalidades, tal como a nossa, impõe, como necessidade imperativa, a formação, por convicção racional, da consciência nacional: a criação e o desenvolvimento, par en haut - da inteligência para os hábitos, do raciocínio para os reflexos, - do instinto de conservação e de progresso nacional. (ibidem, p.131, grifo do autor)

Àquela altura, às vésperas da Primeira Guerra Mundial, manuais didáticos e a literatura paradidática já vinham atuando em prol da formação par en haut do nacionalismo brasileiro junto às novas gerações e ministrando conscientemente "antídotos" contra os vários perigos reais ou imaginários que ameaçavam o Brasil.

\section{Ideologia e nacionalismo}

Na década de 1960, Dante Moreira Leite já podia declarar, com convicção, que o patriotismo ou nacionalismo foi sempre "imposto de cima para baixo, num movimento intelectual e político" e que a vitalidade e permanência da propaganda nacionalista, acentuada 
em "períodos de crise ou guerra", indicava que o nacionalismo era "sustentado pela educação e pelos veículos de comunicação de massa" (Leite, 1976, p.19). Segundo a perspectiva crítica do autor, o nacionalismo não poderia resultar simplesmente de uma "análise objetiva das características nacionais"; construído mediante a "exaltação das qualidades de um povo", via de regra comparado a outros "considerados inferiores", o nacionalismo sempre pressuporia uma "afirmação de poder e grandeza". Quanto à tese de que haveria nacionalismos "saudáveis" e nacionalismos "doentios ou destrutivos”, sugeriu que não seria difícil encontrar representantes da segunda categoria; bastaria, por exemplo, mencionar o nazismo. $\mathrm{Na}$ primeira categoria, poderia ser enquadrado o nacionalismo dos países sul-americanos, o qual seria "frequentemente defensivo" e forma de "afirmação nacional diante do imperialismo" e resistência ao "expansionismo de outros países" (ibidem, p.20).

Resultado de doutrinação ideológica, a nação seria essencialmente cosa mentale, podendo ser definida, segundo Benedict Anderson (2008, p.32), como uma "comunidade política imaginada" com limites definidos, mas soberana em seu território. A nação tem de ser, necessariamente, imaginada porque seus membros não podem conhecer-se pessoalmente, embora todos "tenham em mente a imagem viva da comunhão entre eles”. Concebida sempre como uma "profunda camaradagem horizontal", a despeito de acentuadas diferenças internas de classes e regiões, a nação suscita um tal sentimento de fraternidade que dispôs "milhões de pessoas", na história recente, "não tanto a matar, mas sobretudo a morrer por essas criações imaginárias limitadas” (ibidem, p.34).

Corroborando as teses de Anderson, Eric Hobsbawm sugeriu que a nação moderna pode vir a "preencher o vazio emocional causado pelo declínio ou desintegração, ou a inexistência de redes de relações ou comunidades humanas reais" e que as pessoas aderem a esse sucedâneo porque "os Estados e os movimentos nacionais podem mobilizar certas variantes do sentimento de vínculo coletivo já existente e podem operar potencialmente, dessa forma, na escala macropolítica que se ajustaria às nações e aos Estados modernos" 
(Hobsbawm, 2011, p.58). A esse respeito, deve-se acrescentar que a formação das nações não dispensa "o elemento do artefato, da invenção e da engenharia social” (ibidem, p.20).

Hobsbawm mencionou a escola primária como parte da "maquinaria de comunicação" acionada pelos Estados "para difundir a imagem e a herança da 'nação' e inculcar a adesão a ela”, bem como para vincular os habitantes "ao país e à bandeira" (ibidem, p.106). No Brasil, como demonstraram os textos já comentados de Veríssimo, Romero e Bilac, foram alguns intelectuais que apontaram a importância da escola e dos livros destinados às crianças para a constituição do nacionalismo "defensivo" brasileiro, antes mesmo que o Estado investisse largamente na instrução primária. As três obras paradidáticas que aqui se analisam definiram os contornos do nacional como forma de combater os "perigos" daquele tempo.

\section{Contos pátrios}

Segundo Humberto de Campos, os Contos pátrios foram escritos às pressas por Olavo Bilac e Coelho Neto com a finalidade de resolver dificuldades financeiras do poeta parnasiano, que fora obrigado a exilar-se em Minas Gerais durante a Revolta da Armada. Em 1894, o autor do romance A conquista teria apresentado ao editor Francisco Alves duas propostas de edição: um romance e um livro de contos escolares (Campos, 1954, v.1, p.74). A aceitação imediata da segunda proposta e, antes disso, a sua própria formulação já indicavam clara percepção, por parte dos envolvidos no negócio, de uma demanda real a ser atendida.

Concebidos como livro de leitura escolar, os Contos pátrios acabavam por acentuar um dos aspectos da "duplicidade congênita" da literatura destinada à criança. Por um lado, deixavam em segundo plano o atendimento dos "interesses da criança", que lhe propiciaria um "meio de acesso ao real" ao favorecer "a ordenação de experiências existenciais, através do conhecimento de histórias, e a expansão de seu domínio linguístico" e, por outro, colocavam ênfa- 
se na contribuição para o "processo de dominação do jovem, assumindo um caráter pedagógico, por transmitir normas e envolver-se com sua formação moral" (Zilberman; Magalhães, 1982, p.14).

O livro, com efeito, continha histórias exemplares e modelos de comportamento de modo a aconselhar ou recomendar padrões de conduta que pudessem combater o egoísmo, a ganância e o preconceito. Para os propósitos deste ensaio, interessam os contos que tratavam especificamente do Brasil e do amor a ele devido.

Abria justamente o volume uma narrativa ambientada em região fronteiriça não nomeada que sofria inesperada invasão de destacamento militar estrangeiro cuja origem não se esclarece. Os "sertanejos", prevenidos por um companheiro que testemunhara o desembarque dos inimigos, prepararam-se para a resistência apesar de sua acentuada inferioridade numérica. Acabaram expulsando os invasores graças ao fator surpresa, uma vez que os estrangeiros não contavam com uma reação imediata, e principalmente devido à coragem e à valentia.

A superioridade moral dos sertanejos resultava da consciência de que defendiam não apenas suas propriedades, suas vidas e as de seus familiares, mas principalmente algo muito maior, como se percebia na fala de um dos heróis: "-Se morrermos, todos os nossos corpos ficarão marcando a fronteira da Pátria. Pelas nossas ossadas e pelas cinzas de nossas cabanas, os que vierem mais tarde conhecerão o limite do Brasil" (Bilac; Coelho Neto, 2001, p.10). Por isso, os bravos sertanejos abriram fogo gritando "viva o Brasil”. Quando o rarefeito bando de patriotas apresentou-se vitorioso à margem do rio que demarcava a fronteira, o narrador insinuaria a aprovação do grande feito no próprio aspecto da eterna natureza: "a selva grande e veneranda parecia aplaudir os seus filhos valentes com a sua grande voz murmurosa e constante" (ibidem, p.12).

Pode-se dizer que Bilac e Coelho Neto levaram tão a sério seus papéis de apóstolos cívicos que abriram o volume com uma parábola, pois a indefinição das balizas espaço-temporais da narrativa evidenciava seu caráter alegórico e seu propósito pedagógico e moralizante é por demais evidente. Cabe apenas notar que o inimigo 
é, a princípio, sul-americano, haja vista que atravessa um rio para penetrar em território brasileiro. A propósito, ainda havia em 1894 litígios territoriais com Argentina e Bolívia, por exemplo.

O sétimo conto, intitulado "O recruta", narrava a transformação sofrida por Anselmo, um campônio forte, trabalhador, corajoso e analfabeto, que durante a Guerra do Paraguai tornou-se "voluntário de pau e corda". Quando os soldados responsáveis pelo "recrutamento" chegaram à sua terra, não nomeada, "houve quem fugisse". Anselmo, ao contrário, submeteu-se, mas se sentindo contrariado por razões que o narrador esclarecia:

Para a sua alma inculta e primitiva de filho da roça, a Pátria não era o Brasil: era o pedaço de terra que ele regava com o suor de seu rosto. Fora daquilo não havia mais nada. Que tinha ele com o resto do mundo? Por que havia ele de vestir uma farda, e ir morrer abandonado e desconhecido, sem uma amizade, sem uma simpatia, numa terra [sic] de questões que não entendia e que não eram suas? (ibidem, p.46)

Evocando circunstâncias histórias específicas, Bilac e Coelho Neto não ousaram atribuir ao rústico camponês um patriotismo consciente. Se sua terra fosse invadida pelos paraguaios, ele os enfrentaria em defesa "do seu ganha-pão, do seu trabalho, dos seus hábitos", mas não lhe ocorreria jamais "ir defender o Sul, ir defender o Imperador" (ibidem).

Conduzido ao Rio de Janeiro, Anselmo ficaria confinado ao quartel, recebendo treinamento e submetendo-se à dura disciplina militar, que se impunha com insultos e castigos físicos. Entretanto, a convivência com os companheiros de farda foi operando uma lenta mudança no espírito do camponês, que na Corte, tão longe de sua terra, veio a encontrar "o mesmo céu, a mesma língua, quase os mesmos costumes" (ibidem, p.49). Finalmente, convivendo com os soldados antigos, aprendeu a odiar o inimigo Solano Lopes.

No dia da partida, desfilando por ruas "cheias de povo", no ritmo da banda marcial, Anselmo deixou-se invadir pelo entusias- 
mo e já não via a hora de bater-se com os paraguaios. Mas a conversão final do bairrista em patriota ocorreu quando a banda atacou o hino nacional e um "vento brando" desfraldou a bandeira brasileira: "E, então, ali, a ideia sagrada de Pátria se apresentou, nítida e bela, diante da alma de Anselmo". Nessa hora, o relutante "recruta" de outrora compreendeu "que a sua vida valia menos que a honra da nação" e desejou "morrer gloriosamente, abraçado às dobras daquela formosa bandeira" (ibidem, p.50). Com a história de Anselmo, os autores ofereciam às crianças em idade escolar o prazer de julgarem-se privilegiadas ou mesmo superiores por assimilarem o patriotismo racionalmente sem precisar seguir a via empírica ou intuitivo-sentimental percorrida pela personagem rústica e analfabeta.

$\mathrm{Na}$ décima narrativa do livro, os autores não necessitaram recorrer à inventiva para apresentar aos seus jovens leitores exemplos de patriotismo abnegado. Bastou-lhes evocar um episódio heroico da cidade do Rio de Janeiro, que no dia 11 de setembro de 1710 foi invadida por cerca de mil soldados liderados por Jean-François Duclerc. Pequena e mal armada, a guarnição militar concentrou-se em torno do palácio do governador Francisco de Castro Morais, deixando o restante da cidade desprotegido. Os invasores já marchavam pelo centro da cidade quando, na Rua Direita, depararam com uma "multidão de moços" que, com armas improvisadas, partiram para um assalto desesperado: "Aquela mocidade robusta e alucinada, a que o amor da pátria dava forças sobre-humanas, combatia cega, delirante, sem cuidar de regras e leis de batalha" (ibidem, p.62). Era de tal forma valorosa a resistência, que os soldados de Duclerc bateram em retirada e, pouco depois, capitularam.

Em 1909, Coelho Neto e Bilac recheariam A Pátria brasileira de episódios heroicos do passado nacional.

No final dos Contos pátrios, Bilac e Coelho Neto inseriram narrativa intitulada "Pátria nova". Tratava-se, na verdade, de um diálogo entre dois imigrantes napolitanos, pai e filha. Em um belo domingo de sol e pasmaceira, o colono "já quase velho" isolara-se de todos e afundara em melancólicas meditações. Sofria de saudades de sua terra - "terra ingrata", garantia o narrador, "que não 
tinha pão bastante para dar a tanta gente" (ibidem, p.107) -, de onde partira, para sempre, havia exatos dez anos. Foi arrancado de sua cisma pela chegada da filha, "forte mulher, ainda no verdor da idade", que trazia nos braços uma criança adormecida. Ao saber do motivo que deixava seu pai entristecido, a jovem confessou-lhe que, naquele dia, também acordara com saudades de sua aldeia, onde deixara as "companheiras de folguedos" e a sepultura da mãe. Decidira, no entanto, nada dizer para não magoar o pai, imaginando que este não se lembrasse. A resposta do colono, no entanto, foi lapidar: "Quem esquece a sua terra não tem coração" (ibidem, p.109). Torcendo as rédeas da conversação, a jovem napolitana procurou dissipar a melancolia do pai, aconselhando-o a esquecer, assim como ela, que estaria disposta a não pensar mais no assunto: “- $[. .$.$] foi aqui que vi felizes todos os meus, foi aqui que casei, foi$ aqui que nasceu o meu filho, o seu neto... Por que é que não hei de amar esta terra, como se ela fosse a minha?" (ibidem).

Diante da reação escandalizada do pai, que lhe perguntara se seria capaz de esquecer a sua terra, a jovem sentiu a necessidade de explicar-se melhor:

- Não! esquecer não posso... não posso... Mas diga-me: a terra de lá é que é a sua, e é a que é a minha... qual é, porém, a desta criança que aqui está, que nasceu aqui e que vai crescer ignorando a língua que nós mesmos já vamos esquecendo e vendo todos os dias, da infância à idade madura e à velhice, esta pátria da liberdade e da riqueza? Olhe! veja como ela bate palmas, contente a este sol que a viu nascer! (ibidem)

Sensibilizado pela alegria transbordante da criança, o velho acabou deixando-se convencer: "- Tens razão, filha! Esta é a terra de teu filho, esta é a pátria do meu neto: por que é que não há de ser também a nossa terra?” Tomando a criança nos braços, erguia-a e abaixava-a exclamando: “- Bravo, brasileirinho!” (ibidem, p.110).

Conscientes da relevância numérica e econômica dos imigrantes no final do século XIX, Bilac e Coelho Neto forjaram para eles uma 
lição especial de patriotismo. Mas, sintomaticamente, escolheram suas personagens entre imigrantes italianos, cuja exemplar integração à cultura brasileira era bem mais acentuada em comparação com a dos alemães.

\section{Porque me ufano do meu país}

Afonso Celso de Assis Figueiredo Júnior, filho do visconde de Ouro Preto, presidente do último Conselho de Ministros do Império, publicou Porque me ufano do meu país em 1901, ainda em comemoração do IV Centenário do Descobrimento. A epígrafe "Right or wrong, my country" não deixava dúvidas sobre os propósitos da obra, com a qual o autor pretendia, conforme declarou no primeiro capítulo, ensinar "patriotismo" aos filhos. Sucesso editorial e leitura obrigatória nas escolas por décadas, o livro ainda seria muito criticado por seu nacionalismo ingênuo e acrítico, ${ }^{3}$ que passou a ser denominado "ufanismo". ${ }^{4}$ A ingenuidade, no entanto, talvez fosse apenas aparente.

Com Porque me ufano do meu país, as crianças aprendiam que o Brasil era "um dos mais vastos países do globo" (Celso, 1943, p.12); que seu "gigantesco território" representava "um resumo da superfície do planeta, exceto as regiões polares" (ibidem, p.15); que não havia "no mundo país mais belo" (ibidem, p.19); que possuía quatro maravilhas capazes de "notabilizar um país", a saber: o Amazonas, a cachoeira de Paulo Afonso, a floresta virgem e a baía do Rio de Janeiro (ibidem, p.21); que o seu solo, "um imenso escrínio de gemas" (ibidem, p.41), continha riqueza "extraordinária” em ouroe diamantes; que na agricultura e na pecuária poderia "produzir tudo quanto reclama[sse]m as necessidades físicas do homem" (ibidem, p.44) e tornar-se, assim, o "celeiro do mundo" (ibidem, p.45); que o clima não opunha obstáculos à presença humana, sendo "raros os

3 "Pegajoso", na pitoresca expressão de Antonio Dimas (1994, v.2, p.542).

4 Sobre edições e a repercussão da obra, v. Bastos (2002). 
casos de insolação ou congelamento" (ibidem, p.50) e, finalmente, que não havia calamidades naturais:

Não há ciclones, como nos Estados Unidos, inundações, como na Espanha, fomes e pestes prolongadas, como em tantos pontos da Europa e da Ásia.

De terremotos não se aponta notícia, nem vestígio. Vulcões, nem apagados, nem traços de extintos. Nevoeiros persistentes não envolvem as nossas costas, onde raros naufrágios ocorrem. (ibidem, p.54)

Sobre as três principais raças que constituíram o Brasil - índios, negros e portugueses -, Afonso Celso assegurava: "Qualquer daqueles elementos, bem como o resultante deles, possui qualidades de que nos devemos ensoberbecer. Nenhum deles fez mal à humanidade ou a deprecia" (ibidem, p.57). Com poucas exceções, os índios seriam dóceis e hospitaleiros; os negros mostraram-se, durante a escravidão, que vigorou até 1888 , capazes de "sentimentos afetivos, resignação estoica, coragem, laboriosidade" (ibidem, p.65); os portugueses deram mostras de seu valor ao construir o Brasil, "esse colosso" (ibidem, p.69); os mestiços revelaram "tenacidade" e "bravura" ao enfrentar um "poderoso exército" em Canudos (ibidem, p.75).

Ao tratar das qualidades da gente e da terra do Brasil, Afonso Celso procurava claramente opor barreiras à ideologia colonialista, que implicava em desprezo pelas regiões tropicais e pelas raças "inferiores". ${ }^{5}$ Considerando a inevitável miscigenação dessas raças no Brasil, o autor não hesitou em declarar: "O mestiço brasileiro não denota inferioridade alguma, física ou intelectual” (Celso, 1943, p.75).

5 No excelente ensaio "De cortiço a cortiço", Antonio Candido (1993, p.1414) discorre brevemente sobre a visão que intelectuais do final do século XIX tinham do "meio" e da "raça" brasileiros. 
A partir do 23ํㅜㄹ cátulo (são 42, ao todo), a obra voltou-se para a história do Brasil, naturalmente coberta de glórias: "Em quatro séculos de história, o número de suas vitórias militares supera sobremaneira o de seus desastres. Estes, sobre escassos e honrosos, nenhuma consequência aviltante produziram. E não tardou a desforra" (ibidem, p.80-1).

Após listar as guerras em que o Brasil se envolveu, assinalou o autor que nelas abundavam "façanhas legendárias, iguais às mais famosas do universo". Feitos heroicos também teriam sido registrados nas guerras civis, mas, quanto a estas, disse apenas que cumpria "esquecer" (ibidem, p.89). Coerentemente, não escreveria uma linha sobre os sobressaltos da República, com exceção da Guerra de Canudos, evocada en passant para, como se viu, ressaltar as qualidades do mestiço, que afinal de contas, se insurgira contra mudanças introduzidas pelo novo regime.

As ações gloriosas ou magnânimas dignas de lembrança para Afonso Celso foram as dos períodos colonial e imperial. Eis algumas de suas lições históricas: "A conquista portuguesa não se caracteriza pelas violências da espanhola..."; "O nosso regime colonial foi mais suave que o de quase todos os povos americanos" (ibidem, p.108-9); "A inquisição não medrou entre nós" (ibidem, p.112). Não cabe discutir a exatidão dessas lições, uma vez que seu objetivo declarado era insuflar o orgulho patriótico dos brasileiros, em cuja história haveria fatos dignos de celebração épica: a ação dos jesuítas, as aventuras dos bandeirantes, a guerra holandesa, a resistência dos Palmares e a retirada da Laguna. Cada um desses episódios foi narrado em capítulo específico, mas insurreições e revoltas que prenunciaram a Independência foram abordadas em meia dúzia de linhas.

Ao destacar os "grandes nomes da história" brasileira, Afonso Celso não deixou dúvidas sobre seu posicionamento político após doze anos de República, pois atribuiu verdadeiro protagonismo histórico ao segundo imperador, D. Pedro II:

Eis o grande vulto da história brasileira. [...] Já começaram a lhe render justiça os próprios que o depuseram do trono e o baniram. 
Consideram-no, pelo menos, um bom, um desinteressado, um amigo da Pátria. Época virá, não mui remota, em que unanimemente se lhe reconhecerá a benemerência, proclamando-o a nação inteira o mais eminente dos brasileiros, o mais nobre dos americanos (sem excetuar Washington e Bolívar), uma das figuras mais simpáticas e veneradas da história universal. (ibidem, p.148-9)

Os republicanos não mereceram menção nominal no livro, mesmo quando se tratava de aludir aos que ousaram "apear" do trono e "banir" da Pátria o seu "grande vulto" que, digno e altivo, "não formulou uma queixa, no meio de tamanhas ingratidões e iniquidades" (ibidem, p.154).

Obrigado a ser otimista, uma vez que o desânimo equivaleria a "uma injustiça, a uma ingratidão" (ibidem, p.168), Afonso Celso não deixou, porém, de observar, discretamente, que a situação que então se enfrentava, após doze anos de República, era "penosíssima" (ibidem). No capítulo dedicado aos "Perigos que ameaça[va]m o Brasil", mencionou francamente suas apreensões: "separação do território nacional em vários Estados; intervenção nos seus negócios de alguma potência estrangeira" (ibidem, p.164-5). Porém, seu "ufanismo" não dava margem ao desespero, pois sabia não haver "antagonismos" entre as partes que compunham o Brasil e contava com a valentia de "quem já expulsou os franceses do Rio de Janeiro e do Maranhão" e "combateu trinta anos e afinal venceu os holandeses” (ibidem, p.165-6).

Mas o monarquista que descrevera o Brasil como um recanto privilegiado do globo confiava, no fundo, em uma proteção ainda maior e mais alta: "Se [Deus] aquinhoou o Brasil de modo especialmente magnânimo, é porque lhe reserva alevantados destinos" (ibidem, p.169). Com sua visão pacífico-idílica do Brasil e de sua história, o conde de Afonso Celso vinha a sugerir o glorioso Império como o resultado espontâneo ou natural da ação de poderosas forças telúricas ou místicas ${ }^{6}$ que não conviria contrariar. Como o Brasil

6 A respeito da perspectiva teológica de Afonso Celso, v. Dimas (1994, p.542-4). 
tinha atingido seu apogeu com o grande estadista D. Pedro II, a "brutal" mudança de regime deveria ser considerada um equívoco.

\section{A Pátria brasileira}

Em crônica publicada no Correio Paulistano em 25 de novembro de 1907, Olavo Bilac listou Afonso Celso entre os quinze ou dezesseis "monarquistas sinceros, seguros, declarados, intransigentes e irredutíveis" do Rio de Janeiro, que não se confundiam com os oportunistas. Estes conviviam muito bem com as autoridades republicanas, obtinham delas favores e vantagens, mas conspiravam clandestinamente pela restauração monárquica (apud Dimas, 2006, v.2, p.103).

Dois anos depois, unir-se-ia novamente o poeta parnasiano a Coelho Neto para escrever A Pátria brasileira, obra destinada à "educação moral e cívica" dos "alunos das escolas primárias". Os autores transformaram vários episódios da história do Brasil em exemplos ou lições de abnegação, solidariedade, bravura e devoção à Pátria. Teriam, portanto, as crianças em quem se espelhar na sua vida adulta.

Zumbi e seus guerreiros do quilombo dos Palmares, por exemplo, foram celebrados como fundadores de uma "república". Apesar de esmagados pelo governo colonial, teriam deixado a lembrança de sua "esforçada luta pela liberdade" (Coelho Neto; Bilac, 1918, p.153).

Felipe dos Santos, que tentou liderar uma rebelião em Vila Rica, atual Ouro Preto, apresentava-se no livro como um "precursor" de Tiradentes. Bilac e Coelho Neto narraram a cruel execução do herói que, amarrado à cauda de um cavalo, foi em 16 de julho de 1720 arrastado pelas ruas, "ensopando com o seu sangue precioso o pó da sua amada cidade” (ibidem, p.178-9). Como não queriam os "donos do país" reconhecer que governavam "não tribos errantes e brutas, mas um povo que sabia compreender o valor do seu esforço" (ibidem, p.171), nova reação seria inevitável: "Daí a poucos 
anos, tinha de aparecer, na mesma terra, outro herói: a causa da liberdade nacional precisava de mais sangue..." (ibidem, p.179).

A grande vítima da "opressão" (título de um capítulo) colonial seria o alferes Joaquim José da Silva Xavier, conhecido pela alcunha de Tiradentes, o único dos inconfidentes a receber a pena capital, por enforcamento, em 21 de abril de 1792. Os autores dedicaram um capítulo especial ao "martírio de Tiradentes" que, segundo eles, se ofereceu serenamente ao sacrifício, "com os olhos pregados no crucifixo" (ibidem, p.201) empunhado pelo padre que o assistia. A vítima revia-se na figura do Cristo porque, como ele, era capaz de dar a vida por quem amava. Esquecido durante o Império, o alferes transformava-se em um dos grandes mitos republicanos, como deixavam claro Bilac e Coelho Neto: "as gotas de sangue do herói não caíram em terreno estéril, porque a árvore de sacrifício se fez árvore de redenção, e a República é o fruto da semente de martírio lançada à terra nessa manhã de abril" (ibidem).

Vítimas igualmente respeitáveis teriam sido os participantes da Revolução Pernambucana de 1817, que adotou a República como sistema de governo. A revolta acabou por ser sufocada e muitos revolucionários foram impiedosamente executados. Mas Bilac e Coelho Neto explicaram aos seus jovens leitores: "O solo, de onde tinha de rebentar a árvore da liberdade, ainda precisava, como adubo, de muito sangue e muita lágrima. Nenhuma grande conquista da humanidade se fez senão com grandes sofrimentos acumulados" (ibidem, p.220).

Após a Independência (1822), funcionava no Rio de Janeiro uma Assembleia Constituinte que, julgando-se soberana, decidira que "todos os soldados de origem europeia apenas pudessem estacionar a uma distância de seis léguas da cidade” (ibidem, p.235). Ao tomar conhecimento da medida, que colocava em dúvida a lealdade dos soldados nascidos em Portugal, D. Pedro I ordenou a dissolução da Assembleia. Ato contínuo, foram presos e expulsos do país vários constituintes, entre os quais José Bonifácio e dois de seus irmãos. O "Patriarca da Independência", que amargaria cinco anos de exílio, era, segundo Bilac e Coelho Neto, vítima de 
imperdoável ingratidão: "Desterrando José Bonifácio, o Imperador castigava aquele que mais serviços lhe prestara. $\mathrm{O}$ grande brasileiro [...] começava a sofrer as consequências da credulidade, que o levara a confiar no constitucionalismo de um filho de reis absolutos" (ibidem, p.236-7).

Em Pernambuco, a medida autoritária não ficou sem resposta. Revolucionários republicanos instituíram a Confederação do Equador que, não obstante, foi logo vencida. Dezessete conjurados pagaram a ousadia com a vida, entre os quais frei Caneca, fuzilado no Recife, e João Guilherme Rattcliff, enforcado no Rio de Janeiro. Mas como esclareciam os autores do livro, o sacrifício não havia sido em vão: "A ideia progredia. Sobre o chão da pátria continuavam a cair cadáveres de mártires. Sobre esse montão de cadáveres tinha de se apoiar um dia, inabalável e vencedor, o ideal republicano" (ibidem, p.237).

Sem nomear um herói particular, Bilac e Coelho Neto prestaram sua homenagem ao farrapos gaúchos que fundaram a "sua república" e "tinham com as suas guerrilhas atordoado e batido os exércitos regulares que o Império lhes opunha” (ibidem, p.250). Para ilustrar o heroísmo desses homens que sustentaram sua independência por dez longos anos (1835-1845), os autores narraram a chegada de um guerreiro à sua querência após a anistia:

No silêncio e no recolhimento da tarde que caía, galopava o gaúcho. Sabia bem que não viria encontrar a família: essa como ele, tinha também seguido os bandos guerreiros; uns tinham morrido, outros erravam ainda... O Farrapo queria ver a sua estância, a sua propriedade. Chegou. Já não viu a larga porteira: tinha sido queimada. Entrou. Nos campos, cheios outrora de criação, havia agora, apenas mato. Não viu a casa, outrora opulenta e bela: a casa era um montão de destroços.

[...]

Que importavam os desastres, a ruína e a miséria?

Tinha-se batido pela liberdade da sua terra... podia dormir tranquilo. (ibidem, p.250-1) 
Convinha aos autores esquecer que esses heróis do pampa se insurgiram contra a ordem instituída e que representaram a mais séria ameaça à integridade política e territorial do Brasil no período imperial. Interessava também a eles esquecer os intuitos separatistas das insurreições que louvaram tão enfaticamente. Oito anos antes, o conde de Afonso Celso já declarara ser necessário esquecer as guerras civis. Estava então provavelmente consciente de que "l'essence d'une nation est que tous les individus aient beaucoup de choses en commun, et aussi que tous aient oublié bien des choses" (Renan apud Anderson, 2008, p.32).

Para Bilac e Coelho Neto, mais importante do que esquecer algumas coisas era certamente poder encontrar no passado antigos anseios republicanos e dar à história brasileira uma interpretação teleológica que fizesse da instituição da República a grande aspiração nacional pela qual se sacrificaram sucessivas gerações de brasileiros. Instituído pelo filho do rei português, que também seria por sua vez rei de Portugal (e, apesar disso, um herói nacional, segundo Afonso Celso), o Império não passara de uma barreira artificialmente imposta à plena liberdade do povo brasileiro. Tal interpretação da história colocava sobre os ombros das pobres crianças em idade escolar a responsabilidade de zelar por um precioso legado, a República, que custara a vida de tantos brasileiros. Em 1909, após a "Regeneração" do Rio de Janeiro, a vitória contra a febre amarela, a resolução dos últimos conflitos de fronteira, a desarticulação das oposições jacobina e monarquista e a consolidação da "política dos governadores", que pacificou os estados e fortaleceu o poder central, os autores podiam, sem corar, exigir dos seus jovens leitores o sacrifício hipotético:

... a República foi feita pacificamente: o povo recebeu-a como a realização de uma esperança antiga.

A República começou sob magníficos auspícios; e, para que ela se torne grande e forte, urge que todos os que nascerem à sombra do seu pavilhão glorioso, num esforço comum e patriótico trabalhem pela sua prosperidade, e não se recusem a defendê-la, no momento 
em que, acenando aos filhos, ela lhes pedir o sacrifício supremo do sangue. (Coelho Neto; Bilac, 1918, p.281)

Bilac e Coelho Neto encerraram prudentemente sua obra com a Proclamação da República, desobrigando-se de tratar dos "heróis" do novo regime. Pouparam-se, assim, a difícil tarefa de narrar, por exemplo, os feitos de Floriano Peixoto, "consolidador da República" para simpatizantes como Coelho Neto e "ditador" para gente como Bilac, que fora preso pelo "Marechal de Ferro".

Em estudo da obra didática e paradidática de Bilac, Marisa Lajolo considerou a literatura escolar da Primeira República instrumento de difusão dos valores da classe dominante apresentados como valores nacionais. Por isso, Antonio Candido pôde, no prefácio, dizer que "Bilac surge do livro de Marisa Lajolo como uma espécie de homem providencial para as necessidades ideológicas das camadas dominantes"; sua "idealização nacionalista" não conceberia o "homem brasileiro" como "ator eventual de uma rebeldia que mudasse as condições de sua vida miserável”, mas sim como "beneficiário de um paternalismo esclarecido" (Candido, 1982, p.10). Em A pátria brasileira, no entanto, Bilac, em colaboração com Coelho Neto, reuniu uma galeria de heróis, propostos como exemplos a serem seguidos, que se insurgiram contra a ordem estabelecida em nome da liberdade, da igualdade e da justiça. Pode-se supor que essas lições não eram especialmente tranquilizadoras para as camadas dominantes...

\section{Conclusão}

Para José Veríssimo, com o advento do novo regime tornava-se imperativo criar livros escolares que pudessem combater o "bairrismo" e favorecer a "integração do espírito nacional". Como para intelectuais como Sílvio Romero e Olavo Bilac a escola era uma instituição estratégica para combater o "perigo estrangeiro" e fomentar a coesão nacional, o "livro de leitura" tornava-se um instru- 
mento fundamental para a constituição par en haut (ou de cima para baixo) do nacionalismo defensivo brasileiro.

Sendo a nação "coisa imaginada", era função da literatura paradidática tornar compreensível, com engenho e arte, a ideia de Nação Brasileira de modo a estimular o sentimento de fraternidade e vínculo coletivo entre as crianças, independentemente de sua origem regional, social ou étnica para que elas pudessem agir com a mesma abnegação e fervor patriótico dos sertanejos da fronteira, do camponês Anselmo ou dos jovens cariocas que enfrentaram Duclerc. Sendo estrangeiras ou filhas de imigrantes, que pudessem, ao menos, sentir gratidão pelo rico e generoso país que as acolhia.

Entretanto, além dessa "camaradagem horizontal", seria igualmente importante a solidariedade com as sucessivas gerações que ajudaram a construir o Brasil. Como dissera Renan, a essência de uma nação implica que todos os indivíduos tenham coisas em comum e esqueçam muitas coisas. As acentuadas divergências entre Porque me ufano do meu país e A Pátria brasileira tornam evidente que, na construção consciente do nacionalismo, pode haver entendimentos conflitantes acerca do que merece ser lembrado e do que deve ser esquecido. De caso pensado, o monarquista Afonso Celso e os republicanos Olavo Bilac e Coelho Neto projetaram sobre o passado nacional as dissensões do presente que viviam. Sem recursos para resistir à doutrinação e talvez ávidas por conhecer o Brasil, as crianças da Primeira República eram induzidas a tomar um partido, sem provavelmente supor que o faziam. 


\section{6 \\ Retratos e poemas de 0 Álbum (1893-1895) de ARTUR AzEVEDO ${ }^{1}$}

A LETRADA. - Escreva alguma coisa no meu álbum. Faço questão de possuir um autógrafo seu.

O POETA. - Oh! minha senhora, não vale nada. Que sou eu?... A LETRADA. - Como! um dos nossos mais ilustres poetas!... Sabe que a sua modéstia é escandalosa, se assim me posso exprimir. Quero o autógrafo.

O POETA. - Pois bem, minha senhora, tê-lo-á, já que tanto insiste na sua nímia gentileza, porque nada mais é do que gentileza... A LETRADA. - Eu não sei lisonjear ninguém. Tenho-o na conta de uma das águias da nossa literatura, um dos luminares da poesia. Os seus versos encantam-me, deliciam-me!

O POETA. - Oh! muito obrigado! por quem é!... realmente, estou confuso... Que lhe hei de escrever?

A LETRADA. - Um pequenino conto, uma poesia, um pensamento... Não tem nenhum pensamento?

O POETA. - Tenho... tenho mesmo mais de um.

1 Primeira versão deste artigo foi divulgada na coletânea Questões de crítica e historiografia literária, organizada por Luiz Roberto Velloso Cairo e Maria Eunice Moreira (2006), a quem se dedica esta nova publicação. 
A LETRADA. - Pois é isso, contanto que seja uma coisa nova e bonita. Isto não é recomendação que se faça a um espírito original e encantador como o meu amigo...

O POETA. - Está bem. Empreste-me o seu álbum, que lho trago daqui a três dias.

A LETRADA. - O quê? Vai levar todo esse tempo para me dar um autógrafo? Nada! nada! Demais, o meu álbum não sai de casa. É uma questão de princípio... Faça favor de escrever já.

O POETA. - Já? oh! diacho! (Coimbra, 1895, p.2)

O Álbum surgiu em janeiro de 1893 das oficinas gráficas de $\mathrm{H}$. Lombaerts \& Cia com a promessa de manter-se durante um ano mesmo sem vendas significativas. ${ }^{2}$ A novidade desse hebdomadário sem charges ou caricaturas era o emprego da fotografia, que finalmente se conseguia imprimir em grandes tiragens sem perda de qualidade gráfica. Em cada número, composto de oito páginas repletas de colaboração literária, seria encartado, em papel especial, "um retrato de pessoa notável", 3 que viria acompanhado de um breve estudo biográfico escrito preferencialmente por um colaborador convidado.

Ao cabo de um ano, O Álbum constituiria, como esclarece o "Cavaco preliminar", uma "interessante galeria". Artur Azevedo (1855-1908), o editor, considerava importante fixar a fisionomia das celebridades dos primeiros anos da agitada República: "Parece-nos que na época de renovação que atravessamos, neste surgir constante de fisionomias, nesta volatização social de velhas figuras do Segundo Império, uma folha deste gênero terá mais tarde o seu valor documentário" (Azevedo, 1893, p.1).

2 Havia apenas quatro pontos de venda de números avulsos no Rio de Janeiro: a Companhia Fotográfica Brasileira, responsável pela fototipia, e as livrarias Lombaerts, Enciclopédica e Lachaud.

3 Segundo nota da redação, os exemplares não poderiam ser enviados pelos Correios sob pena de inutilizaram-se as "fototipias" (n.3, jan. 1893, p.18). 
Não era a primeira vez que Artur Azevedo aventurava-se em empreendimento semelhante. Já estivera à frente da Revista do Rio de Janeiro (1877), da Revista dos Teatros (1879), da Gazetinha (1880-1881) e da Vida Moderna (1886). Com 55 números lançados de janeiro de 1893 a janeiro de 1895, O Álbum foi, apesar de ocasionais suspensões, a mais longeva das publicações dirigidas pelo comediógrafo. A despeito da posição pró-Floriano, a circulação dessa revista, como de resto a de outros periódicos cariocas, foi interrompida em novembro de 1893 por causa das hostilidades dos marinheiros liderados por Custódio José de Melo durante a Revolta da Armada. Os assinantes somente voltariam a receber $O$ Álbum em abril de 1894, mas a publicação seria novamente suspensa da segunda semana de junho a agosto de 1894, falta que, segundo o editor, os leitores deveriam atribuir "à preguiça, - moléstia nacional de que todos nós mais ou menos sofremos" (idem, 1894, p.393). O Álbum reapareceria em setembro daquele mesmo ano, mas com apenas dois números, 50 e 51. Os números 52 e 53 sairiam, respectivamente, em outubro e novembro de 1894; em janeiro de 1895, viriam à luz os dois últimos números do hebdomadário (54 e 55).

Além da biografia de uma celebridade, outras seções mantiveram-se desde o início no periódico. A "Crônica fluminense" comentava os principais acontecimentos da semana; o "Teatro" fazia breves apreciações sobre os espetáculos em cartaz. Ambas as seções eram escritas por Artur Azevedo, ${ }^{4}$ que as assinava, respectivamente, com a inicial A. e o pseudônimo X.Y.Z. Ausente de alguns números, a crítica literária, que muitas vezes não ia além da notícia de lançamentos, foi publicada sob rubricas variadas ${ }^{5}$ por Cosimo e Amarante, pseudônimos do editor.

Outras rubricas foram menos regulares. Surgida logo no primeiro número, a seção "Sport", dedicada ao mundo do turfe, não apa-

4 Quando viajou para a Bahia no final de junho de 1893, o autor de O tribofe deixou a redação dos números 22 e 23 entregue aos cuidados de Valentim Magalhães.

5 Via de regra, a seção era encimada pelo título da obra resenhada. 
receria no número três porque, segundo esclarecimento da redação, não poderia concorrer com publicações especializadas ou com seções similares de outros periódicos. A partir do número 40, Elói, o Herói, pseudônimo de Artur Azevedo, publicaria esporadicamente "De palanque", coluna de breves notas sobre assuntos diversos.

Apesar do destaque reservado à fotografia, $O$ Álbum dedicava a maioria de suas páginas à colaboração literária, no que em certa medida fazia jus ao título. Um dos grandes temores de um poeta ou romancista do século XIX era, muito provavelmente, o de ser inadvertidamente interpelado por admiradora mais ou menos entusiástica que lhe exigisse com bons ou maus modos uma pequena contribuição para o seu álbum (v. citação anterior de "Diálogos", Coimbra, 1895, p.2). Esse objeto, guardado como um verdadeiro tesouro, era um caderno mais ou menos luxuoso destinado a recolher frases, aforismos ou, preferencialmente, poemas originais adrede escritos para a imperiosa adolescente ou mesmo respeitável matrona por literatos em evidência. Não havia saída para o requerido a não ser derramar sobre as folhas do relicário algumas palavras reunidas às pressas. A recusa, sobre ser recebida como uma afronta ou descortesia imperdoável, transformaria a admiradora da véspera em inimiga impiedosa de todo o sempre. O próprio periódico atesta a prática ao transcrever poemas que afirmava haverem sido escritos nos álbuns de distintas senhoritas cariocas: Adelaide Amoedo e as poetisas Zalina Rolim e Adelina Vieira. Com o título escolhido para o seu periódico, Artur Azevedo talvez quisesse fazer dele um repositório para criações literárias inéditas. Como indicava a paginação contínua, os números da revista constituiriam ao final de doze meses um grosso volume de 416 páginas. Com efeito, O Álbum divulgou contos, poemas e um romance-folhetim do comediógrafo Alfredo Bastos (1854-?). Essa narrativa seriada, intitulada Amor de primavera e amor de outono (tipos de mulheres), ficou incompleta com o fim do periódico. ${ }^{6}$

6 O n.55 já não a traria. 
No entanto, o título do periódico também aludia ao conhecido objeto destinado a colecionar fotografias. O primeiro retratado por $O$ Álbum de Artur Azevedo foi o compositor de óperas Carlos Gomes (1836-1896); o segundo foi Machado de Assis (1839-1908), o que talvez fizesse supor que os escritores fossem prestigiados pela revista. Entretanto, o grupo melhor representado foi o dos políticos, cujas fotografias ocuparam as páginas da revista treze vezes (cerca de 23,5\%). Embora nove escritores fossem retratados, o grupo dos plumitivos correspondeu a apenas cerca de $16,5 \%$ do total de fotografias. ${ }^{7}$ Outros grupos foram representados em proporção semelhante; na galeria de $O$ Álbum, encontram-se oito músicos e/ou compositores, sete médicos, seis atores, três jornalistas, três empresários, três engenheiros, um religioso, um educador e um militar. $^{8}$

Entre os escritores homenageados por Artur Azevedo, havia dois ficcionistas, quatro poetas, um crítico literário e dois dramaturgos, o brasileiro Moreira Sampaio (1851-1901) e o português

7 Consideram-se aqui apenas os que eram publicamente reconhecidos como escritores. Como se sabe, políticos, jornalistas e profissionais liberais também publicavam na imprensa contos, crônicas e poemas que às vezes recolhiam em livros pouco lidos. Afonso Celso, por exemplo, que havia publicado vários livros de poesia, foi considerado político, pois suas obras significativas ainda não haviam sido publicadas.

8 Eis a relação completa na ordem de publicação: Carlos Gomes, Machado de Assis, Ismênia dos Santos, João Lopes, Furtado Coelho, Alcindo Guanabara, Monsenhor Brito (Luiz Raimundo da Silva Brito), Joaquim Abílio Borges, Assis Pacheco, Martins Júnior, Alfredo Barcelos, Abdon Milanez, Olavo Bilac, Henrique de Mesquita, Ermelinda de Sá, Moreira Sampaio, Cândido Barata Ribeiro, Antônio Azeredo, José Carlos de Carvalho, Henrique Chaves, Eduardo Garrido, Domingos Freire, Antônio Dias Ferreira, Comendador Ribeiro de Carvalho, Abel Parente, Luiz Murat, Xisto Bahia, Afonso Celso, Cardoso de Meneses, Luís Gomes, Ferreira de Araújo, Francisco Portela, Valentim Magalhães, Antônio Jannuzzi, Fontoura Xavier, João Rosa, Henrique de Sá, Luís Cruls, Epitácio Pessoa, Augusto Rosa, João Batista Capelli, Artur Napoleão, João Clapp, Visconde de Alvarenga, Costa Sena, Francisco Vale, Cassiano do Nascimento, Silva Araújo, Moniz Freire, Marino Mancinelli, Alfredo Madureira, Coronel Lacerda, Lamounier Godofredo, Aluísio Azevedo e Leonor Rivero. 
Eduardo Garrido (1842-1912). O primeiro foi parceiro de Artur Azevedo na criação de revistas de ano bem-sucedidas como O Mandarim (1884), Cocota (1885), O Bilontra (1886), Mercúrio (1887) e O Homem (1888); o segundo celebrizou-se como autor de duas centenas de comédias, mágicas e farsas. Para ambos, quem escreveu as breves biografias foi Artur Azevedo, que considerava Moreira Sampaio "um dos mais legítimos herdeiros de Martins Pena" (A., 1893, p.121) e Eduardo Garrido um grande escritor "para o arranjo de mágicas e operetas" (ibidem, p.161).

Embora fosse chamado de Mestre pelo editor do hebdomadário, que se declarava honrado por poder publicar seu retrato, Machado de Assis não contou com uma biografia expressamente escrita para a ocasião. O Álbum limitou-se a transcrever artigo de 1885 publicado por Artur Barreiros (1856-1885) em periódico não mencionado.

Entre as obras do Mestre, Barreiros destacara como mais relevantes Crisálidas (1864), "gérmen e embrião", e Memórias póstumas de Brás Cubas (1881), a "obra-prima, a mais trabalhada e a mais saborosa", que haveria revelado o "filósofo adorável, de um ceticismo, nem brutal nem desumano, - gota a gota adquirido como um veneno irresistível, - indócil, religioso à sua maneira”. O que, entretanto, continha o artigo de mais interessante era um retrato moral de Machado, um "vivo e alegre camarada", que se fazia "rapaz com os rapazes"; um ídolo modesto, que não elogiava "com a intenção de agremiar caudatários”, não se impunha, não almejava vantagens materiais nem estimulava aclamações; um homem arredio, que evitava o contato com o público "por temperamento, por um augusto e elevado sentimento de independência e liberdade", mas se mostrava, "no trato íntimo, discreto, polido, admirador e seguidor das práticas britânicas, gentleman, em uma palavra” (idem, 1893, p.9-11).

Após o artigo de Barreiros, o editor incluiu uma nota complementar relatando brevemente a carreira de Machado na imprensa e no funcionalismo público. Esse acréscimo indicava que o texto selecionado para fazer as vezes de um esboço biográfico não era adequado para essa finalidade. Para $O$ Álbum, o texto verbal talvez fosse mero acessório do clichê fotográfico, novidade técnica que encantava. 
O Álbum retrataria outro ficcionista somente nos estertores da publicação (Bilac, 1895, p.10-1). O escolhido foi Aluísio Azevedo (1857-1913), que era, casualmente, irmão do editor. Para biógrafo ad hoc do naturalista, elegeu-se o poeta Olavo Bilac (1865-1918), que era seu amigo pessoal.

O poeta parnasiano encareceu as dificuldades que o romancista enfrentou em sua adolescência, em que se viu obrigado a exercer atividades incompatíveis com as suas aptidões. Naquele tempo, Aluísio Azevedo sonhava em ser pintor e, com os rudimentos que aprendera com um imigrado italiano, Domingos Tribuzzi, aventurou-se na curiosa profissão de retratista de defuntos, em que precocemente revelava os seus pendores estéticos.

Nesse tempo já o dominava a ardente preocupação da verdade na Arte. Os outros retratistas pintavam os seus mortos como cocottes, - lábios tintos a vermelhão, olhos cuidadosamente cerrados, faces barbeadas de fresco, indo para o fundo da cova como para um salão de baile. Nas telas de Aluísio, o pavor e a fealdade da morte se mostravam sem disfarce: um olho mal fechado, a cor terrosa da face descomposta, um dente cariado entre os lábios do morto, - tudo aparecia fielmente reproduzido no quadro. (ibidem)

Bilac também revelou que, na sua primeira estadia no Rio de Janeiro (1876-1878), onde trabalharia como pintor e ilustrador de periódicos, Aluísio Azevedo travara relações com os boêmios Artur de Oliveira (1851-1882), Fontoura Xavier (1856-1922) e Teófilo Dias (1857-1889), que o atraíram para a literatura.

O biógrafo destacou a importância histórica de O mulato (1881), recebido como obra "francamente abolicionista", escrita por um "processo novo" em que se notava "o amor intransigente e fervoroso da verdade". Apesar da grande repercussão, o romance naturalista haveria despertado a oposição dos gramáticos porque suas personagens "falavam a língua do Norte, essa língua máscula já rica de brasileirismos; não usavam o duro português de lei” (ibidem). 
Ao final do artigo, Bilac listou todas as obras escritas por Aluísio Azevedo, inclusive uma comédia em um ato que fora encenada por um empresário sem o devido pagamento dos direitos autorais. $\mathrm{O}$ caso suscitou-lhe considerações sobre a condição do trabalho intelectual no Brasil, onde nem mesmo um escritor brilhante e profícuo como o biografado conseguia retribuições condignas.

Se me perguntardes agora o que tem ele lucrado com esse esforço, com essa vida terrível, que quebra os nervos, espatifa o estômago, fulmina a alma e o corpo, - não vos direi nada. Há coisas em que não é bom tocar.

Paro aqui, porque a minha pena poderia escrever duras linhas, duras e inúteis, em que viesse palpitar a profunda indignação que me sacode, às vezes, quando vejo que o Brasil esquece aqueles que mais têm trabalhado para a sua glória. (ibidem)

O protesto do poeta foi ouvido. Naquele mesmo ano, Aluísio Azevedo ingressaria por concurso na carreira diplomática, abandonando completamente a literatura.

Os poetas retratados por $O$ Álbum talvez fossem cinco, mas Lúcio de Mendonça (1854-1909), biógrafo de Valentim Magalhães (1859-1903), valorizou principalmente a produção crítica do autor de Cantos e lutas (1879), que já havia publicado ensaios em O escândalo (1888) e Escritores e escritos (1889), mantivera a coluna "Notas à margem" na Gazeta de Notícias (1885-1886) e dirigira de 1885 a 1888 o hebdomadário A Semana, que voltara a circular em $1893^{\circ} \mathrm{e}$ constituía importante veículo de divulgação da poesia parnasiana e da ficção naturalista (Mendonça, 1893, p.257-8).

Dos quatro poetas restantes, dois já não atraíam o interesse do público de então. Segundo biógrafo anônimo, Martins Júnior (1860-1904) destacara-se como pioneiro do "cientificismo" na poesia com a publicação de Vigílias literárias (1879), Visões de hoje (1881), Retalhos (1884) e Estilhaços (1885), mas adquirira sólida

9 Essa segunda fase do periódico encerrar-se-ia em 1895. 
reputação como político que ocupara cargos públicos importantes em Recife (A., 1893, p.73-4).

Já Fontoura Xavier, cuja biografia foi esboçada pelo editor da revista, iniciara-se na poesia quando estudante em São Paulo (18761877), onde escrevera $O$ régio saltimbanco (1877), sátira em versos. Depois, colaborara na imprensa carioca (1877-1881) e auxiliara o biógrafo na Gazetinha (1881). Finalmente, seguira para o Rio Grande do Sul, sua terra natal, para redigir um jornal republicano. Segundo Artur Azevedo, Machado de Assis dissera que o poeta "abraçara um ideia política para ter pretexto para os seus versos socialistas”. Xavier tornar-se-ia conhecido como poeta após a publicação de Opalas (1884), cujos versos seriam "corretos, másculos, vibrantes, sem nenhum sensualismo, sem nenhuma pieguice erótica” (A., 1893, p.273-4). ${ }^{10}$ No ano em que era reverenciado por $O$ Álbum, já seguia a carreira diplomática.

Poeta e cronista prestigiado, Bilac foi homenageado por seu amigo íntimo Guimarães Passos (1867-1909), que para ele escreveu "Biografia express" - uma imitação confessa do portrait documenté do jornal L'Echo de Paris. Do “carioca da gema” Bilac, o biógrafo narrou resumidamente a vida de estudante, as primeiras atividades na imprensa e as primeiras glórias literárias. No jornal A Rua, Bilac assinara crônicas sob o pseudônimo de Arlequim. Com essa colaboração, revelara-se prosador elegante e correto e fundara "definitivamente a crônica no Brasil".

Passos também apresentou uma breve descrição física do poeta, indicou seus gostos e preferências em vários campos, descreveu características marcantes de sua caligrafia e chegou a assumir o papel de vidente que advinhara o futuro do biografado nas linhas das mãos. Além disso, tornou pública a rotina cotidiana do poeta; soube-se então que se deitava tarde e não tinha hora para levantar-se, que lia todos os jornais com “cuidado extraordinário”, que almoçava no hotel, que tomava vermute às quatro horas da tarde etc.

10 No artigo "Os primeiros baudelairianos", Antonio Candido (1987, p.32) refere-se ao acentuado erotismo com laivos de sadismo de Fontoura Xavier. 
Nas mãos do biógrafo, Bilac transformou-se em astro do mundo artístico, cuja intimidade poderia interessar às suas legiões de admiradores (Passos, 1893, p.97-8).

A biografia de Luís Murat (1861-1929), cujos versos inundavam os periódicos cariocas, saiu uma semana depois do retrato, pois Bilac, o biógrafo, estivera adoentado. O poeta das Panóplias (1888) aproveitou a oportunidade para protestar contra a precária condição dos escritores no Brasil.

...os que vierem depois de nós hão de agradecer-nos este sacrifício nobre, este trabalho ingrato de estar fazendo [sic] o desbravamento do caminho entre as assuadas dos imbecis. Nem ninguém nos paga, nem ninguém nos lê. Fazendo arte neste meio de mercantilismo inconfessável e de política baixa, provocamos um escândalo tão grande como o dos anjos, que baixaram a Sodoma e tiveram de fugir horrorizados... (Bilac, 1893, p.201-1)

Para Bilac, a obra de Murat seria "o remate do trabalho de três gerações literárias"; cada página por ele escrita seria "como a galeria de um museu, onde o visitante é obrigado a demorar-se meia hora pelo menos diante de cada tela". No entanto, o que fazia de Murat o "marechal da poesia brasileira" seria o seu "poder de fechar dentro da sua poesia toda a alma do homem moderno, todas as suas dúvidas, todas as suas esperanças, todos os seus amores, todos os seus desesperos" (ibidem).

Como se nota, as biografias de escritores publicadas no hebdomadário não foram além de considerações gerais e sempre laudatórias sobre as obras. Os biógrafos preferiram exaltar as virtudes cívicas, as glórias mundanas, o sucesso profissional e as qualidades pessoais dos ídolos literários.

Interrompido no terceiro número do segundo ano, $O$ Álbum não constituiu uma galeria que pudesse ser considerada representativa da literatura contemporânea. Retrataram-se apenas nove escritores. As falhas são clamorosas. Entre os ficcionistas, notavam-se as ausências de Raul Pompeia e Coelho Neto; entre os críticos, as de 
José Veríssimo, Araripe Jr. e Sílvio Romero; entre os poetas, as de Alberto de Oliveira, Raimundo Correia e Cruz e Sousa; entre os dramaturgos, a de Artur Azevedo. Para esta última lacuna, o editor apresentou uma justificativa aceitável na resposta em versos a um soneto-requerimento do padre Correia de Almeida (1820-1905), que exigia um retrato do autor de $O$ tribofe.

Dos retratos compete-me a escolha;

Todos sabem que o Álbum é meu;

$\mathrm{E}$, portanto, o retrato na folha

Todo o mundo o terá, menos eu. (A., 1893, p.151)

Assumindo a responsabilidade pela direção da galeria de $O$ Álbum, Artur Azevedo revelava o caráter subjetivo das escolhas. Dos nove escritores prestigiados, seis eram seguramente seus amigos pessoais. Dos 55 retratados, pelo menos dezessete (cerca de $31 \%$ ) possuíam vínculos com o universo dos teatros cariocas em que Artur Azevedo cultivava relações amistosas. Além de não fazer jus ao prestígio social de que a literatura desfrutava no final do século XIX, O Álbum prestou-se à louvação recíproca (os biografados Machado de Assis, Aluísio Azevedo, Luís Murat, Olavo Bilac e Valentim Magalhães também foram, por sua vez, biógrafos) no interior de uma pequena igrejinha.

Dos retratados na revista, apenas Machado de Assis, Martins Júnior, Olavo Bilac, Luís Murat, Valentim Magalhães e Fontoura Xavier colaboraram com poemas. ${ }^{11}$ Destes, quem mais publicou foi Valentim Magalhães com três textos, dois dos quais assinados com os pseudônimos Marcos Valente e M. V.

Entretanto, os que mais publicaram versos em $O$ Álbum foram Artur Azevedo e Adelino Fontoura Chaves (respectivamente, 17 e 15 poemas), que juntos responderam por cerca de $17 \%$ do total (mais de 187 poemas). Compreende-se perfeitamente a supremacia

11 As considerações a seguir correspondem ao estado da coleção consultada, a que faltam as páginas 259 a 262 (n.33, ago. 1893) e 413 a 416 (n.52, out. 1894). 
do editor, que tanto se aproveitou de uma situação privilegiada para divulgar sua produção, quanto foi, provavelmente, muitas vezes obrigado pelas circunstâncias a preencher espaços em branco com o que estava à mão; dessa necessidade talvez decorram muitos dos versos de circunstância (satíricos e humorísticos) do poeta. Assim como havia percalços, que ficaram documentados, no recebimento das biografias encomendadas, não há porque pensar que fosse diferente com a colaboração literária. O que não se compreende tão imediatamente é a intensa participação de Adelino Fontoura (1859-1884), cujos versos ficaram espalhados em periódicos e apenas tardiamente, por iniciativa de amigos, foram postumamente recolhidos e organizados por Múcio Leão no livro Dispersos (1954). Da autoria de Fontoura (1893, p.150), liam-se em O Álbum poemas de teor romântico como o transcrito abaixo.

\section{CONFRONTO}

Olha esta flor, escuta-lhe os queixumes...

Retrai-se a pobrezinha, meu amor!

Menos bela que tu, sente ciúmes;

Não tem perfume junto aos teus perfumes...

É menos flor que tu, mimosa flor!

Com O Álbum, Artur Azevedo dava uma pequena contribuição para que não fosse esquecido o amigo, com quem havia trabalhado em A Gazetinha no início da década de 1880. Colaborador entusiasmado da campanha abolicionista, Fontoura fora em 1884 designado por José do Patrocínio correspondente em Paris da Gazeta da Tarde. Após adoecer gravemente na capital francesa, faleceu em Lisboa quando viajava de volta ao Brasil.

Dos outros dez principais colaboradores, ${ }^{12}$ apenas o padre Correia de Almeida (1920-1905) era muito conhecido do público

12 No total, esses poetas responderam por cerca de 35\% dos poemas publicados em $O$ Álbum. 
carioca por intensa colaboração em periódicos e por vários livros publicados com boa repercussão. Haviam publicado livros de poesia Júlio César da Silva (1874-1936), A. Peres Jr. (1865-1943), Emílio de Meneses (1866-1918) e Leônidas de Sá (1867-1902), mas não se poderia dizer que fossem poetas consagrados. Cunha Mendes Jr. (1875-1934), Bento Ernesto Jr. (1866-1943), Alfredo de Magalhães (1873-1943), Artur Andrade (1872-1902) e Georgina Teixeira (?) eram inéditos no período de publicação da revista conforme levantamento realizado em obras de referência. Entre os poetas que contribuíram modestamente com até três poemas encontravam-se Guimarães Passos (1867-1909), Olavo Bilac, Martins Júnior, Osório Duque-Estrada (1870-1927), Alberto de Oliveira (18571937), Valentim Magalhães, Figueiredo Pimentel (1869-1914), Fontoura Xavier, Lúcio de Mendonça, Luís Murat, Machado de Assis e Raimundo Correia (1859-1911), que eram, sem sombra de dúvida, muito conhecidos do público carioca por livros publicados e/ou pela atuação como jornalistas. Esses medalhões responderam por cerca de um décimo dos poemas publicados. Com isso, conclui-se que Artur Azevedo dedicou a sua revista principalmente à divulgação de poetas iniciantes - uma legião de mais ou menos sessenta vates. ${ }^{13}$

Em setembro de 1893, Cosimo (pseudônimo de Artur Azevedo) registrou a publicação de Broquéis, de Cruz e Sousa (1861-1898), no mesmo artigo em que noticiava uma reedição de Encarnação, de José de Alencar, e os lançamentos de A normalista, de Adolfo Caminha, e A Capital Federal, de Coelho Neto. O cronista reconheceu que Cruz e Sousa era um dos poetas "mais apreciados pela

13 A imprecisão justifica-se porque, além das já mencionadas lacunas na coleção, encontraram-se as iniciais J. de A. e os prováveis pseudônimos Fricinal Vassico, E. le Mouel, Edme Paze, Vicomte de Borelli e Paulo Augusto, que não se pôde atribuir com segurança a nenhum escritor. Entre tantos poetas, havia apenas cinco mulheres: Adelina Amélia Lopes Vieira (1850-?), Francisca Júlia da Silva (1874-1920), Georgina Teixeira (?), Maria Clara da Cunha Santos (1866-1911) e Zalina Rolim (1869-1961). 
novíssima geração literária" e que possuía "uma correção de forma muito para louvar" naquela "época de nefelibatismos" (Cosimo, 1893, p.302-3). Fez esta última afirmação com toda a segurança, pois examinara detalhadamente todo o livro, no qual encontrara somente um verso "errado": "Teu coração lembra a orgia dos triclínios”. O poeta simbolista passou, portanto, quase incólume pela prova máxima a que um poeta era submetido pela crítica militante de então, pois versejava de acordo com normas consensuais. No entanto, o cronista de $O$ Álbum não deixou de apresentar com ironia ferina restrições ao autor.

Mas... maldito mas!... escreve o poeta coisas que eu não entendo, não sei se por um defeito da minha inteligência, o que é provável, ou por uma enunciação muito subjetiva das suas impressões, o que é possível. Em todo o caso, ignoro o que seja um "sonho branco de quermesse" e outras coisas que não cito para não alongar esta notícia. (ibidem)

Cosimo não ficou indiferente aos versos de Cruz e Sousa, nos quais percebeu uma "música estranha", cujos sons, no entanto, passaram "ligeiramente" pelos seus ouvidos e "se perderam ao longe" sem deixar a lembrança de um simples acorde.

Após assim depreciar uma das maiores qualidades do poeta simbolista - a musicalidade -, o cronista considerou os poemas de Broquéis "incontestavelmente monótonos, porque só ferem uma corda e têm todos a mesma forma endecassílaba". Entretanto, concedeu que, lido isoladamente, qualquer um dos poemas poderia causar "outro e melhor efeito". Para que o leitor examinasse a sua hipótese transcreveu de Broquéis o soneto "Primeira comunhão". Logo a seguir, dirigiu-se aos seus leitores: "Não entenderam? Nem eu. Mas faz bem ao ouvido, não acham? Contanto que não se leia outro do mesmo gênero em seguida”. Em 1893, quando surgiram os primeiros livros simbolistas de Cruz e Sousa, Missal e Broquéis, já estavam, portanto, forjadas as principais armas que os adeptos do Parnasianismo brandiriam contra os desprezados nefelibatas: 
acusações de monotonia e imperícia na versificação e de ausência de sentido nos versos. ${ }^{14}$

Além de Cruz e Sousa, seis outros autores cujos nomes ficaram associados ao movimento simbolista estamparam poemas em $O$ Álbum; entretanto, esses simpatizantes do Simbolismo, entre os quais se contava Emiliano Perneta, amigo do Dante Negro, publicaram exclusivamente versos parnasianos. ${ }^{15}$ Apenas três nefelibatas puderam estampar poemas claramente simbolistas no periódico de Artur Azevedo: Figueiredo Pimentel (1869-1914), Júlio César da Silva (1874-1936) e Antônio Lima (1864-?). Pimentel, conhecido jornalista, divulgou na revista um plangente "Réquiem..." em que, invadido por recordações dolorosas, se declarava morto. A terceira estrofe do poema, por exemplo, na qual se encontram substantivos elevados à categoria de símbolos mediante o uso de maiúsculas, léxico litúrgico (de cerimônias fúnebres) e combinações de luminosidade e brancura, é nitidamente simbolista.

\author{
Lá vem a Noite... A Claridade branca \\ Da Lua escoa um Plenilúnio morto, \\ Como os tocheiros da Eça d'algum Morto, \\ Porque estou morto! \\ (Pimentel, 1893, p.295)
}

14 Em março (n.12), Amarante (1893, p.93) já havia proferido sua sentença sobre Missal, de que fora enviado um exemplar à redação. $\mathrm{O}$ resenhista fora contundente ao apontar as debilidades do livro: "Falta-lhe tudo: falta-lhe alma, que é a ideia, falta-lhe destreza, falta-lhe graça, falta-lhe movimento, o que só se obtém com imaginação e propriedade de estilo, falta-lhe, enfim, o dom de convencer o leitor e conquistar-lhe a simpatia, o que em literatura é sempre o resultado da sinceridade com que pintamos as nossas paixões e as nossas impressões. / O que não lhe falta são adjetivos de algibeira e frases torturadas a canivete e retorcidas ao fogo; tão torturadas e tão retorcidas, que deixam de ser arte para ser unicamente caprichos de paciência".

15 Eis a lista completa: Emiliano Perneta, Artur Lobo (1869-1901), Luís Rosa (1869-1895), Moreira de Vasconcelos (1859-1900), Pethion de Villar (18701924) e Cunha Mendes. 
Já Júlio César da Silva, irmão de Júlia Lopes da Silva, publicou três poemas simbolistas em $O$ Álbum, apesar de haver ousado fazer uma cândida recomendação ao editor na carta que fez acompanhar seus versos: "Não repare nos alexandrinos; aqui por S. Paulo já se não segue a rotina do hemistíquio. Alexandrinos assim, com contínuas variações de ritmo, parecem-me preferíveis a esses que por aí se fazem".

Muito embora denotasse consciência da renovação que o Simbolismo introduzia no verso ao superar a rigidez rítmica parnasiana, essa infeliz lembrança do paulistano permitiu ao seu destinatário assumir um irônico tom paternal em sua resposta. Nela, em "Enviando-nos o soneto..." (1893, p.62), Azevedo deu conselhos ao poeta iniciante - a quem provavelmente julgava um provinciano pretensioso - para que este não se deixasse iludir por duvidosas novidades.

Ao jovem poeta, que nos deu um livrinho tão formoso e tão prometedor com as Estalactites [1891], pedimos com muito empenho que não se deixe levar pelas extravagâncias e pela falsa independência da literatura das brasseries de Paris. Os alexandrinos fazem-se como sempre se fizeram ou não se fazem.

Faça Júlio Cesar da Silva versos como os das Estalactites, melhorando-os ainda, se for possível, ou não os faça absolutamente. Quem não quer sujeitar-se a regras de metrificação escreve prosa.

Apesar de indispor-se contra o orgulhoso nefelibatismo do poeta paulistano, o editor de $O$ Álbum não deixou de divulgar seus versos, assim como faria com Figueiredo Pimentel e Antônio Lima. Graças a essas poucas exceções, não se pode dizer que Artur Azevedo haja imposto um veto aos poetas simbolistas; no entanto, não resta dúvida de que $O$ Álbum era um veículo privilegiado de divulgação da poesia parnasiana, inclusive reforçando a predileção dessa estética pelo soneto. No periódico, mais de 117 sonetos foram publicados (cerca de 62,5\% dos poemas).

Poetas estrangeiros também foram prestigiados por Artur Azevedo, que nesse particular revelou gosto bastante eclético. O leitor 
de $O$ Álbum pôde ler em francês um poema inédito do romântico Victor Hugo, um longo poema do mestre parnasiano Auguste Dorchain e um soneto do simbolista Stéphane Mallarmé. No entanto, o poeta estrangeiro que mais publicidade alcançou no periódico foi Joséphin Soulary (1893, p.129), de quem se transcreveu o soneto "Rêves ambitieux". Esse poema tornou-se objeto de um concurso de tradução de que participaram dezesseis concorrentes e de que saiu vencedor o polígrafo Silva Ramos (1853-1930). A publicação no hebdomadário de pelo menos oito poemas em francês e a intensa participação dos leitores no concurso demonstravam inequivocamente a difusão da língua de Racine no Brasil. Até mesmo um brasileiro, Carlos Magalhães de Azeredo (1872-1963), publicou em O Álbum um soneto em francês.

\section{BAISER VENGEUR}

De toi, qu'un autre - époux odieux! - va presser Sur son cœur, t'énivrant d'un amour que je blâme Je ne voudrais qu'un seul baiser, maudite femme, Dût le ciel m'en punir, dût l'enfer m'écraser!

Dans ce plaisir de mort, cet horrible baiser, Dont l'âpre désespoir serait l'unique flamme, Je saurais mettre tous les transports de mon âme. Et, flétrissant ma vie entière, l'épuiser!

Il serait, plutôt qu'un baiser, une morsure, Qui te ferait souffrir la fièvre lente et sûre, Dont nous ronge un désir toujours inassouvi!

Et je ne serais en toi, dans tes yeux, dans ton rêve, Vivant, toujours vivant, sans relâche et sans trêve... Et je ne craindrais plus ce que je crains: l'Oubli! (Azeredo, 1894, p.367)

Esse beijo intenso e assombroso, que possuiria o condão de conquistar para sempre, apesar das interdições religiosas e sociais, uma 
mulher casada que, para contrariedade do poeta, ainda se sentia embriagada com os ocasionais transportes amorosos do legítimo esposo - esse beijo por que ansiava o poeta transformar-se-ia em mordida que mais do que fazer sofrer, despertaria na amada um desejo exigente e para sempre insatisfeito.

A despeito de empregar língua estrangeira, o jovem Magalhães de Azeredo retomava em meados da década de 1890 a maneira dos poetas estudados por Antonio Candido em "Os primeiros baudelairianos". Notam-se em "Baiser vengeur" o gosto pela depravação e certa perversidade com laivos de sadismo, que seriam próprios do poeta das Flores do mal, e também a violência devoradora do impulso amoroso, que seria, naqueles poetas brasileiros, um desenvolvimento original de certos traços sutis do poeta francês. Segundo Candido (1987, p.23-38), Carvalho Jr., Teófilo Dias e Fontoura Xavier, jovens republicanos, deformavam o modelo "segundo as suas necessidades expressivas, escolhendo os elementos mais adequados à renovação que pretendiam promover e de fato promoveram" nas instituições brasileiras.

Assim como seu irmão Aluísio, Artur Azevedo muito provavelmente esteve ligado a esses poetas por laços de amizade e afinidade ideológica. Note-se que Fontoura Xavier foi homenageado por $O$ Álbum com biografia escrita pelo próprio editor, além do retrato costumeiro. Artur Azevedo e os três baudelairianos foram estudados por Machado de Assis em "A nova geração", ensaio publicado na Revista Brasileira em dezembro de 1879. Dos integrantes desse grupo de poetas, foram honrados em $O$ Álbum com retrato e biografia Valentim Magalhães e Afonso Celso, além do já mencionado Fontoura Xavier.

Magalhães de Azeredo não foi o único a recuperar o exacerbado erotismo dos primeiros baudelairianos. Cunha Mendes (18751934), por exemplo, estampou em $O$ Álbum, sob a epígrafe "Poema da carne", dez sonetos ${ }^{16}$ dedicados a Artur Azevedo, dos quais se transcreve a seguir o quarto.

16 Três anos depois (1896), Cunha Mendes lançaria livro de versos com o título de Poemas da carne. 
Que delicado olor vai-se espalhando em torno!

E o acre aroma gostoso, esse aroma de carne

Dá-me o ímpeto brutal por que louco descarne

Teu belo corpo ideal, acetinado e morno...

Sangue! Belo seria em cada leve adorno

Uma gota sanguínea! Ah! o delírio se encarne

Nessas veias azuis mais que os jardins de Marne

Cheirosas. Patenteia o nítido contorno,

A plástica serena, os assombrosos traços

Da beleza triunfal: dá-me a grandiosa cruz,

Para eu morrer feliz em teus formosos braços!

Deixa o beijo picar-te os lábios de romã:

Que eu sinta o casto amor do místico Jesus

Com as delícias brutais do trágico Satã!

(Mendes, 1893, p.252)

Nota-se, nesse soneto, que o sadismo, manifestado no impulso de devoração espicaçado pela iminente posse da amada e na insólita sede se sangue, associa-se a anseios masoquistas. O poeta deseja lançar-se aos braços da amada abertos em cruz para conciliar, numa crucifixão de nova espécie, os satânicos prazeres sensuais com o divino amor sublimado. A propósito, as duas últimas estrofes apresentam elementos caros à estética simbolista: um símbolo religioso a cruz - e duas personagens que personificam os princípios metafísicos do Bem e do Mal. Entretanto, enquanto no Simbolismo o impulso amoroso é sublimado, nos versos de Cunha Mendes concepções transcendentes são empregadas para traduzir sensações físicas, o que configura uma clara reversão do impulso ascensional da estética simbolista.

Embora com título alusivo aos castos álbuns de donzelas igualmente castas ou até mesmo de dignas matronas, o periódico de Artur Azevedo veiculava textos pouco recomendáveis às suas 
virtuais leitoras, respeitáveis representantes da elite carioca. Nem mesmo a língua francesa poderia amenizar o teor libertino de um soneto de Edme Paze (1894, p.389):

\section{ENCORE}

Sur les satins frôleurs mollement étendue, Dans l'adorable nu de nos premiers parents, La pointe de ses seins rigidement tendue, Elle geint de plaisir en spasmes effarants.

Les flancs gonflés d'ivresse, au désir qui la tue Elle immole sa chair avec des mots troublants; Ses nerfs surexcités tordent ses deux bras blancs, La volupté l'étreint; elle est morte, rendue!

Des cris plaintifs, tels ceux d'un enfant qui vagit, S'échappent de sa bouche, ou la pourpre rougit

Sous la cinglante ardeur du feu qui le dévore,

Et, tandis qu'elle allume, au fond de ses yeux clairs,

Dans un dernier plaisir, d'hystériques éclairs,

D’une voix presque éteinte elle murmure: "Encore".

Calcule-se o efeito de quadro pintado com cores tão vivas na edificação moral de donzelas que eram obrigadas a esperar pacientemente puras pelo noivo adequado à posição social da família... Alguns dos poemas do hebdomadário não poderiam jamais ser inscritos no álbum de uma moça sem causar escândalo... ou secreta excitação. Considere-se, por exemplo, o poema "Vem!", de Paulo Augusto (1893, p.115):

Escrúpulos?... Escrúpulos!... Tolice...

Corre a meus braços! Vem! Não tenhas pejo!

Traze o teu beijo ao encontro do meu beijo...

E deixa-os lá dizer que isto é doidice! 
Não esperes o gelo da velhice,

Não sufoques o lúbrico desejo

Que nos teus olhos úmidos eu vejo!

Foges de mim?... Farias mal?... Quem disse?

Ora o dever! - o coração não deve!

Não creias que um sincero amor ultraja

Reputação de arminho, alva de neve.

Vem! Que o teu sangue férvido reaja!

Amemo-nos, meu bem, que a vida é breve,

E outra vida melhor talvez não haja...

Nesse soneto, o poeta dirige-se resolutamente à amada hesitante a fim de convencê-la a entregar-se aos prazeres do amor. Ele procura induzi-la a desprezar as previsíveis censuras de outras pessoas não identificadas (quarto verso da primeira estrofe) e satisfazer o desejo que visivelmente a tomava (segunda estrofe). Para vencer os escrúpulos dela, lembra-lhe que a vida é efêmera e que a velhice, incompatível com o amor, não tarda; também insinua maliciosamente que o amor sincero, ainda que contrário ao dever, não poderia manchar uma reputação até então impoluta. Com esses frágeis sofismas e a paráfrase dos versos que Horácio dirigiu a uma jovem em circunstâncias similares ("carpe diem quam minimum credula postero"), ${ }^{17}$ o poeta pretende sobrepujar em seu benefício interdições tacitamente aceitas e reiteradamente impostas pela família e pela religião. No último verso, chega a colocar em dúvida a existência de um plano transcendente onde os justos e castos pudessem ser premiados por abrir mão das seduções do mundo. Propósitos tão subversivos não eram muito adequados a um periódico que pretendesse conquistar as famílias cariocas.

Com calor mais ou menos intenso, vários poetas de O Álbum feriram a nota erótica. Em alguns casos, empregaram a insolente

17 "Goza o dia de hoje, que bem incerto é o dia de amanhã." 
franqueza dos realistas; em outros, o comedimento neoclássico dos parnasianos à maneira da poesia sensual de Olavo Bilac. Observe-se, não obstante, que em meados da década de 1890 os principais poetas brasileiros ou afetavam a marmórea impassibilidade parnasiana ou deixavam-se invadir pelo torturado espiritualismo dos simbolistas. Por estarem miudamente imbricados nos veios principais do Parnasianismo e do Simbolismo, ocasionalmente afloravam no terreno irregular de $O$ Álbum os veios secundários do Realismo poético e do Romantismo. Assim, a revista ilustrada de Artur Azevedo confirmava de modo peculiar que, na poesia, as estéticas prevalecentes jamais conseguem suplantar as predecessoras completa ou definitivamente. Conclui-se, considerando-se esse caso particular, que os periódicos do século XIX são fonte importante para a história da literatura ao deixarem registrados complexos entrechoques e insuspeitadas conciliações entre poéticas divergentes. 


\section{7 \\ AS RESENHAS DE LIVROS SIMBOLISTAS NO VESPERTINO A NotíCIA $(1897-1905)^{1}$}

Na história da literatura brasileira, o nome de José Joaquim de Campos da Costa Medeiros e Albuquerque (1867-1934) está associado ao surgimento do Simbolismo no Brasil por haver publicado uma "Proclamação decadente" no livro Pecados, de 1889, e por intitular outro livro do mesmo ano de Canções da decadência. Contribuição talvez mais importante teria dado ao trazer da Europa para o Brasil em 1887 livros simbolistas que fez circular entre alguns amigos.

Se, apesar do título, o seu segundo livro devia muito mais ao Realismo poético e ao Parnasianismo, o livro de estreia apresentava elementos simbolistas. Embora fosse dedicada a Olavo Bilac, a citada "Proclamação decadente" era uma carta aos poetas datada de "20 de Floreal, sendo Verlaine profeta e Mallarmé - deus real". Nela Medeiros e Albuquerque lamenta os "tempos malditos" em que viviam os poetas. Como "todas as crenças morreram", previa que os "Poetas do Sentimento [...] morrer[iam] do Esquecimento / na profunda soledade", pois os seus cantos desapareciam "na indi-

1 Este ensaio foi divulgado originalmente em 2010 na coletânea Intelectuais e imprensa, produzida pela editora Nankin, do Prof. Dr. Valentim Facioli, a quem se dedica esta republicação. 
ferença sombria". A sonoridade dos versos seria o último baluarte dos poetas.

Pode a Música somente
do verso nas finas teias
conservar no tom fluente
tênue fantasma de ideias;

porque é preciso que todos

no vago dessa moldura

sintam os estos mais doudos

da emoção sincera e pura;

creiam achar no que apenas

é tom incerto e indeciso

dos seus sorrisos e penas

o anseio exato e preciso.

Que importa a Ideia, contanto

que vibre a Forma sonora,

se da Harmonia do canto

vaga alusão se evapora?

(Albuquerque, 1889, p.147-9)

Como se nota, o poeta de Pecados defendia a musicalidade dos versos como veículo de sugestão de ideias sutis, o que seria uma das principais concepções simbolistas. A convicção de que o poeta seria capaz de captar e expressar sensações ou sentimentos vagos e imprecisos transparece também no "Soneto decadente", que se acompanha da seguinte epígrafe de Paul Verlaine: "Car nous voulons la nuance encore, / Pas la couleur, rien que la nuance” (ibidem, p.61).

Outro traço simbolista dos Pecados, presente na "Proclamação decadente", é o emprego de substantivos elevados à categoria de símbolos mediante o emprego de maiúsculas, como se vê logo no início do volume, na primeira estrofe de "Para o nada": 
Sempre ao Bem excede a escura

projeção negra do Mal!

O Gênio, o Crime e a Loucura

são faces de um só cristal... (ibidem)

Apreciado por parnasianos e simbolistas franceses, mas sempre representando a ousadia e a renovação na poesia, Charles Baudelaire está presente em "Cães...", uma paródia de "Une charogne", como se nota nas seguintes estrofes:

Vi no centro da rua, na cidade, um pobre cão apodrecido e morto, o olhar vidrado, vagamente absorto, do espaço azul fitando a claridade.

Sobre a boca convulsa numa funda contração de agonia dolorosa enxameava a multidão ruidosa das moscas verdenegras, nauseabunda! (ibidem)

Entretanto, o livro Pecados não continha exclusivamente o novo, pois conservava elementos do Parnasianismo - perfeitamente representado pelo soneto "Estranho mar" (ibidem, p.55), que narra o nascimento de Vênus - e até mesmo do Realismo poético, que se manifesta nos versos de "Caro Victrix".
Ah! se eu podesse [sic] compassar meus hinos
pela cadência do teu corpo brando, quando te vejo sob mim arfando em suspiros dulcíssimos, divinos... (ibidem, p.50)

Anos depois, Medeiros e Albuquerque tornar-se-ia crítico de rodapé do vespertino carioca A Notícia, assinando com o pseudônimo J. dos Santos a coluna semanal "Crônica literária", responsável pela notícia e pela resenha de livros recém-lançados. Às vezes, um 
único texto tratava de três ou quatro lançamentos. Como o conceito de literatura era bastante abrangente para aquele discípulo de Sílvio Romero, a seção não se restringia apenas a obras literárias; dedicava-se, pelo contrário, a publicações de todas as áreas do conhecimento: Direito, Medicina, Filosofia etc.

Essa intensa atividade crítica de Medeiros e Albuquerque iniciou-se justamente no período em que o movimento simbolista desenvolvia-se e procurava angariar adeptos e conquistar o público leitor. Considerado o seu vínculo com as origens do movimento, poder-se-ia supor que o crítico de A Notícia fosse um poderoso aliado dos simbolistas na divulgação de suas ideias e obras. Entretanto, ao noticiar e resenhar obras simbolistas, formulou avaliações severas e muitas vezes sarcásticas acerca delas. Importa aqui considerar que concepções estéticas nortearam o trabalho de Medeiros e Albuquerque e como foram recebidas por ele as propostas de renovação poética implícitas nos livros simbolistas, especialmente nas obras póstumas de Cruz e Sousa (1861-1898).

Ao resenhar livros de poesia, o crítico deixava transparecer seus critérios de origem parnasiana ou neoclássica quanto à métrica, às rimas, ao emprego de metáforas e à escolha lexical.

A publicação dos Versos proibidos, de Marcos de Castro, pseudônimo de Alberto Ferreira Ramos (1871-1941), permitiu a J. dos Santos, em 11 de fevereiro de $1898,{ }^{2}$ estender-se em considerações sobre a métrica em língua portuguesa. $\mathrm{O}$ crítico atribuiu a existência de "versos desgraciosos" no livro à busca, pelo poeta, de ritmos novos, do que resultara uma predominância de versos de oito e nove sílabas. Segundo o crítico, os octossílabos seriam resultado da influência do livro Os simples, de Guerra Junqueiro, e da campanha de poetas franceses pela reforma da metrificação. Reconhecia J. dos Santos que o uso quase exclusivo do alexandrino levava a pensar, como faziam de resto escritores franceses notáveis, que somente

2 Para todos os textos da "Crônica literária" aqui citados, encontram-se, nas referências bibliográficas, dados complementares como a página e a distribuição do texto nas colunas do jornal. 
esse metro seria adequado para a expressão de ideias de "certa elevação e grandeza”. Compreendia também que os poetas franceses manifestassem sua insatisfação por estarem submetidos à "tirania de uma infinidade de regrinhas vexatórias e inúteis". No âmbito da poesia de língua portuguesa, ao contrário, os versos de sete e de dez sílabas haveriam servido para a "expressão das mais altas e nobres ideias" como demonstrariam as obras de Castro Alves e Antero de Quental. Além disso, a poesia de língua portuguesa dispunha "da mais ampla variedade de expressões e ritmos dentro das formas habituais de metrificação: as de 6, 7, 10 e 12 sílabas”. Admitia J. dos Santos que as formas de oito e nove sílabas nada tinham de novo, mas observava que estavam "justamente abandonadas". Segundo seu ponto de vista, a adoção do octossílabo por Junqueiro e seu provável discípulo Marcos de Castro representava um retrocesso porque, enquanto os franceses batiam-se pela variedade de ritmo, esses dois poetas de língua portuguesa empregavam um verso "de uma monotonia muito mais desesperadora que a do alexandrino francês". No caso do poeta brasileiro, aceitava as experiências porque nele reconhecia talento: "quem maneja tão bem as formas correntes da metrificação só as abandona de caso pensado, pelo prazer de aventurar-se em tentativas, que, pelo menos, revelam um justo desejo de originalidade".

Ao resenhar Nimbos, de Luís Edmundo (1878-1961), em 4 de março de 1898, J. dos Santos atribuiu o grande número de rimas "fáceis" no livro à desatenção do poeta, que rimou particípios em ando e indo, adjetivos em ente, oso, osa e ente. Apesar dessa observação, o crítico garantiu não estar empenhado na defesa da "rima rica", que se transformara em chinoiseries na mão de burocratas do verso. ${ }^{3} \mathrm{Na}$ coluna de 12 de junho de 1902, por exemplo, o crítico considerou "estranhas" e "bizarras" as rimas em destaque do soneto "Estranha dor”, recolhido no livro Taça partida, de Daltro dos Santos (?).

3 De memória, J. dos Santos citou versos, cuja autoria declarou ignorar, em que a rima é criada por separação de sílabas: "O meu amigo Ciríaco, / se não fosse brasileiro, / há muito tempo seria co-/ nhecido no mundo inteiro." 
Que é do potente amor que me deu vida? Que é de o glorioso Pendão tendido ao Vento outrora?

Onde jaz do meu mal o salutar remédio e a grande luz do Sol, que eu já não sinto agora?

Que amargor! que atonia! e que infindável tédio! As horas todas são iguais a uma só hora... Alma, sacode o spleen, arremessa-lo, expede-o Bem distante de ti, bem distante e bem fora...

Em consonância com a estética parnasiana, J. dos Santos defendeu o mot juste no texto dedicado aos Nimbos, de Luís Edmundo, o qual, segundo o crítico, deixou de empregar o "epíteto justo" para atender às suas rimas "banalíssimas". Dessa displicência do poeta, surgiriam impropriedades como "paz dulcificante" e "fogo delirante" e a profusão de adjetivos que serviriam apenas ao "enchimento" dos versos. ${ }^{4}$ Já na resenha de Estalagmites, de Hermeto Lima (18721947), publicada no dia 13 de maio de 1898, J. dos Santos afirmou que a "abundância de adjetivos" denotava "indigência de ideias".

É um recurso habitual dos que principiam, para iludir as dificuldades da metrificação. Isso leva o autor a falar num "leito fresco e morno", numa "vasta sala festival, formosa", e a pôr a seguir um braço acetinado que terminava por uma mão sedosa - o que me parece seda demais...

4 Ao resenhar Plumário em 10 de fevereiro de 1905, J. dos Santos condenou um sestro do poeta: "As imagens impróprias são frequentes nos versos do Sr. B. Lopes. Qualquer pessoa dirá que as bocas dos canhões 'vomitaram' a morte. Dir-se-á também, usando a mesma metáfora, que a porta de uma fortaleza, por onde saíam numerosos batalhões, 'vomitava' hostes cerradas sobre o inimigo. Mas o autor do Plumário escreve: / 'Da espada nua, vomitando a morte', o que é uma imagem absolutamente extravagante, porque em uma espada não existe parte alguma que lembre uma boca. De uma espada se diz correntemente que semeia a morte, porque o gesto de quem a está brandindo se pode parecer com o do semeador. Por isso, se escreve também de um guerreiro que ele vai 'ceifando' os batalhões inimigos. São imagens que se compreendem”. 
Não se pense, contudo, que o crítico de A Notícia fosse um adepto, como Coelho Neto, das palavras raras. Ao noticiar a publicação de Relíquias, de Isaías de Oliveira (1864-?), em 17 de setembro de 1900, J. dos Santos citou dois versos do livro - "Um riso festival, onipotente, / raia nos ares lúcidos, opimos" - e comentou: "O que seja um riso onipotente e festival e ares lúcidos e opimos é difícil de imaginar-se".

De Antífonas, de Avelar Filho (?-1900), resenhado em 31 de março de 1900, o crítico transcreveu o poema "No caos", do qual destacou as palavras hostício, fimbo, ebóreo, recacho, sesgo, brônteo, cárdeo e encólpio, cuja significação lhe escapava e nem mesmo os dicionários puderam definir com precisão. Ao noticiar Encíclicas, em 9 de junho de 1905, J. dos Santos atacou a escola do "pernosticismo”, a que se filiara o autor do livro, Teodorico de Brito (?-1916):

Cedendo a uma inclinação muito frequente em jovens escritores, tanto da prosa como do verso, ele acha bonito escolher termos exóticos, com o notório intuito de nos embasbacar ou talvez de nos deixar crer que ele conhece a fundo a língua portuguesa.

Ora, não há nada menos probante. A língua portuguesa tem um depósito formidável de palavras velhas, atiradas para as páginas mais esconsas de antigos escritores, e que ninguém mais emprega. Achá-las para impingi-las aos leitores está ao alcance de quem possua qualquer dicionário.

Dizem alguns que é obra meritória fazer ver que temos todas essas riquezas, ostentando-as. Francamente, o caso é discutível. A maior parte de tão famosos tesouros saiu definitivamente da circulação e não voltará a ela em hipótese alguma. [...] Ver um desses termos, que nunca são empregados, surgir de súbito no meio de um texto moderno, dá-nos a impressão que nós teríamos se encontrássemos alguém vestido com trajes do século XV ou XVI no meio de uma multidão de sujeitos, metidos em sobrecasacas, fraques e casacos, como os que nós usamos hoje.

A moderação, o bom gosto e o senso de oportunidade recomendados por J. dos Santos na seleção lexical revelam orientação neo- 
clássica, da qual são corolários o conceito de mot juste e o combate aos adjetivos supérfluos e ao "pernosticismo" das palavras raras. No âmbito da versificação, o crítico segue critérios parnasianos, pois valoriza o heroico quebrado (seis sílabas), o decassílabo, o alexandrino (doze sílabas) e a forma tradicional das redondilhas maiores (sete sílabas), adotadas por ele próprio em sua "Proclamação decadente", em detrimento do octossílabo e do eneassílabo reintroduzidos na poesia brasileira pelos simbolistas.

Munido desses critérios, J. dos Santos apreciou vários livros simbolistas publicados no período em que respondia pela "Crônica literária" do vespertino A Notícia.

Ao resenhar Austrais: epopeia social e rimas diversas, de Bráulio Prego (1874-1915), em 17 de junho de 1898, o crítico considerou "abominável" o decassílabo "Sim, senhores - maravilhosamente" por não apresentar a "precisa acentuação". ${ }^{5}$ Mas essa era justamente uma novidade introduzida pelos simbolistas, que procuravam romper com as cesuras parnasianas com a finalidade de obter um verso mais fluido.

Na resenha de Cultuais, publicada em 12 de agosto de 1898, J. dos Santos criticou a adjetivação "excessiva, superabundante" do autor, Floriano de Brito (?). Em levantamento minucioso, o crítico verificou a repetição dos adjetivos pálido e lânguido e formas cognatas em várias páginas, o que tomou por indicação de "pobreza de vocabulário" do autor. Mas condenou especialmente o abuso dos adjetivos sutil, mágico e místico, aos quais o poeta haveria dado "uma acepção tão vaga", que eles serviriam "para tudo". Note-se que a significação vaga, que J. dos Santos considerou um defeito responsável pela "impropriedade vocabular" dos versos, era uma meta dos simbolistas, que manifestavam predileção pelo adjetivo místico e cognatos que expressavam a sua orientação espiritualista.

5 Ainda do mesmo livro, J. dos Santos (ibidem) transcreveu o verso "Lanço um olhar sobre os wagons... Num canto", que, disposto entre alexandrinos, não apresentava mais de dez sílabas. "Verifica-se, entretanto, que, tratando de um caminho de ferro, provavelmente da Central, aí sofreu o doloroso acidente que o privou de duas sílabas..." 
Em 9 de setembro de 1898, o crítico de A Notícia transcreveu em sua coluna uma carta que lhe dirigiu o poeta das Cultuais em resposta à resenha do mês anterior. Nela Brito lançou mão do argumento de autoridade para justificar a repetição de adjetivos.

A vez primeira que o extraordinário Wagner - o Dante da música - lançou mão do leitmotiv como processo artístico, processo o mais estético, o mais racional, o mais grandioso e o mais belo, quantos, aliás in bona fide, o não censuraram de se repetir e de se redizer a cada passo? Hoje - e pouco tempo depois! - a sua orientação é um modelo, e a sua maneira é uma escola.

Além disso, Brito assegurou que a repetição de adjetivos era, em sua poesia, totalmente proposital: "Não sou adjetivômano por ser principiante, e sim por escola. O que faço, porém, é não empregá-la senão estudadamente".

J. dos Santos, porém, contestou a tese do leitmotiv ao definir com precisão como compreendia o conceito:

... é um processo aceitável a repetição de um mesmo epíteto acompanhando o mesmo personagem. Um dos recursos habituais de Zola para firmar bem a imagem de qualquer dos seus heróis consiste nisso.

Resta, porém, ver que nas Cultuais uns tantos vocábulos pálido, meigo, lânguido etc. - são repetidos à saciedade e em todas as poesias. A ideia, portanto, de um leitmotiv não se justifica.

Já ao resenhar Via Crucis, de Félix Pacheco (1879-1935), em 17 de setembro de 1900, J. dos Santos destacou a beleza do soneto de abertura, "Ofertório", do qual transcreveu um quarteto.

Arcanjo, Santa, Lírio, Estrela, Sol glorioso,

Filtro que os corações humanos fortalece,

Tamareira que ensombra o deserto arenoso, Mater! Suprema Força! Acolhe minha prece! 
Apesar do elogio, o crítico não deixou de ridicularizar um aspecto notável desses versos.

Neste final, como por quase toda parte [no volume], as letras maiúsculas grelam, cogumelam, empinam-se na ponta dos pés, no meio dos versos do Sr. Félix Pacheco. A isto e a uma certa obscuridade no dizer se limita aliás o seu simbolismo - se é mesmo "simbolismo" que essa cousa se chama...

Com a ironia habitual, J. dos Santos dispensou-se de examinar mais detidamente o significado que as maiúsculas poderiam adquirir nos poemas simbolistas. Dessa forma, ele as reduziu a um mero "cacoete" estilístico, assim como consideraria mera convenção literária o misticismo simbolista. Na resenha de Vae Soli, publicada em 21 de outubro de 1903, reconheceu o mérito do livro, mas tratou com ironia o interesse do autor, Pereira da Silva (1876-1944), por temas religiosos.

Sem dúvida, o autor não deixa de pagar o seu tributo a umas fúteis modas literárias, que fazem abusar das alusões a Santas, a Virgem das Dores, a Sete Espadas... É difícil compreender que, no nosso tempo, se ache poesia em aludir a antigas, tolas e desacreditadas superstições, como o valor cabalístico do número 7, o mau presságio das sextas-feiras e dos dias 13... Mas cada um é da sua época, da sua geração.

A suposta obscuridade simbolista foi frequentemente alvo das farpas do crítico de A Notícia. A resenha de Esotéricas, de Dario Veloso (1869-1937), publicada em 8 de outubro de 1900, iniciou-se pela consideração de que o prefácio do livro constituía "uma salada de citações esdrúxulas dos nomes mais estranhos”. Já os poemas seriam constituídos de "palavras formidavelmente maiusculadas" [sic] e "frases soltas, desconexas, acabando quase todas por pontos de espantação" [sic]. 
Quando resenhou Ulanos, de Jonas da Silva (1880-1947), em 9 de outubro de 1902, J. dos Santos apontou um caso de impropriedade vocabular determinado por força da rima, mas fez uma concessão irônica:

... é [...] possível que o Sr. Jonas da Silva saiba, melhor do que nós todos, o significado das palavras que emprega. A escola (?) a que ele se filia professa, porém, como doutrina um desdém insondável por essa significação. Pouco lhe importa o conteúdo dos termos: o essencial é a sua sonoridade.

Depois, com muito bom humor, denunciou o caráter extravagante das imagens do poeta.

As comparações astronômicas do Sr. Jonas são geralmente estupendas. Aqui lhes dou o que ele descobriu na Via Láctea e na Lua.

Coaxam sapos de luz na luz da Via Láctea

\section{Da Lua o formidando e feroz crocodilo}

Esses dous versos estão na mais espantosa e filosófica e arquiestupefaciente poesia do volume. Intitula-se "Vozes do nada". Por ela se verifica que o Nada, quando dá para falar, diz logo tolices. ${ }^{6}$

6 A primeira obra de Jonas da Silva recebeu uma apreciação favorável de J. dos Santos em 29 de janeiro de 1900: "Ânforas é um delicioso livro de estreia. Há nas suas páginas a promessa de um bom, de um verdadeiro poeta. Há, mesmo, mais do que promessas: há sonetos que já são de um artista”. Entretanto, boa parte da resenha foi dedicada a contestar a "apologia da ignorância" que, segundo o crítico, continha o prefácio de B. Lopes, de quem transcreve um dos conselhos dados ao novo poeta: “... leia o menos possível os mestres para não ficar sem originalidade e estude simplesmente o que diz respeito à sua profissão. Que para fazer bons versos não é preciso que venham livrarias abaixo. Muito pelo contrário: quem muito sabe, o sapiente, quando versos faz, fá-los medonhos". O crítico de A Notícia, ao contrário, recomendou ao estreante que seguisse o exemplo de Dante, Shakespeare e Camões e estudasse muito. Na resenha de Ulanos, chegaria à conclusão de que Jonas da Silva preferiu seguir os conselhos de B. Lopes. 
Os versos de um crítico favorável ao Simbolismo foram muito mal recebidos por J. dos Santos, que iniciou sua coluna de 5 de agosto de 1903 da seguinte forma: "E aqui está um livro detestável: os Pássaros brancos do Sr. Gustavo Santiago (1872-?). Nem forma, nem pensamento, nem mérito algum”. Com início tão contundente, não se admira que a resenha contivesse muitas ironias:

... sublime, positivamente, é o soneto "Bode" de que, para não os indigestionar (por que razão eu também não hei de fazer os meus neologismos?) só lhes darei os seis primeiros versos:

Este, que em mim, acaso, quando saio,

libidinoso e trêmulo e corando,

o olhar me move e a patas de veludo, sinto, infernal, pisando sóis de maio...

Bode sagrado! Viperino ensaio

de homem, que, calmo, no meu ser desnudo!

Um bode que é ensaio de homem, e ensaio viperino, e pisa sóis, sóis de maio, e com patas de veludo - deve ser um bicho assombroso!

Como se nota, o crítico não se empenhou em alcançar o significado de Bode, que é proposto pelo poeta como um símbolo transparente do erotismo. Seu objetivo foi, simplesmente, ridicularizar o aparente hermetismo dos versos.

Em primeiro de julho de 1903, a vítima das ironias de J. dos Santos seria um antigo amigo de Cruz e Sousa.

O livro do Sr. Emiliano Perneta intitulado Alegoria, eu o li de ponta a ponta, sem saltar uma só palavra. Não tive por isso a mínima recompensa. No fim, estava tão adiantado como no princípio: não entendi absolutamente nada.

Sei bem que isso não prova qualquer inferioridade da obra. A inferioridade é de quem não sabe elevar-se até as regiões do Sublime. Logo às primeiras páginas, reconheci minha incapacidade de apreender o sentido misterioso e profundo daqueles nebulosos símbolos. 
Na capa do volume, o crítico haveria encontrado o único trecho compreensível, que fez questão de transcrever: "Publicado em março de 1903, na tipografia de Aníbal Rocha \& C., em Curitiba, Estado do Paraná, Brasil”.

Ao analisar mais detidamente a prosa poética, J. dos Santos criticou Perneta (1866-1921) pelo apego a palavras "difíceis e, não raro, mal empregadas". Após demonstrar que a palavra garnacha fora usada de forma inapropriada, ${ }^{7}$ perguntou-se o crítico:

Para que esse pernosticismo ${ }^{8}$ ridículo? [...] Trata-se de uma escolha de termos bizarros, só para o magro efeito de épater le bourgeois. Mas os burgueses farão coisa mais simples e mais sensata: nunca lerão tais livros!

Que os burgueses nunca lessem os livros simbolistas talvez fosse o grande objetivo da "Crônica literária", pois J. dos Santos sabia da importância da sua função. No prefácio do livro Páginas de crítica, Medeiros e Albuquerque (1920, p.7) esclareceu o que procuravam os leitores dos rodapés de crítica literária: "Em geral, uma opinião que lhes indique se devem ou não ler certos livros". ${ }^{9}$

7 No mesmo fragmento, J. dos Santos também aludiu à grafia peculiar dos simbolistas. "O Sr. Perneta tem um amor extraordinário à ideia de uivos e uivar, que ele escreve, não sei porque, huivos, huiviar e huiviamentos. Aliás, sempre que pode, impinge-nos palavras difíceis e, não raro, mal empregadas. Aqui está um exemplo: 'E sobre os Estetas uma forte garnacha começou de chover furiosamente então'. / Garnacha? / Fui ao dicionário (decididamente estes homenzinhos só são acessíveis por quem se muna de bons dicionários), fui ao dicionário e lá encontrei: 'Garnacha, s. f., vestimenta talar de sacerdote e magistrado'. Como, então, se pode compreender aquele período? Uma vestimenta que chove?"

8 Cabe perceber nessa palavra com destaque gráfico no jornal uma maldosa alusão ao sobrenome do autor cuja obra se examinava. Perneta, aliás, era um apelido com que o poeta passou a assinar.

9 No seu livro de memórias póstumas intitulado Quando eu era vivo, Medeiros e Albuquerque (1942, p.245) afirmaria nunca haver pretendido ser um "bom crítico": "Escrevi apenas impressões ligeiras sobre alguns livros, mas sem nenhuma aspiração de reger o mundo literário”. 
Ao resenhar Astros mortos, de Saturnino de Meireles Filho (1878-1906), em 21 de outubro de 1903, J. dos Santos considerou o poeta um "discípulo digno" do mestre, Cruz e Sousa, a quem a obra era dedicada: "O verso é bem feito, cadenciado, com rimas bem sonoras, mas, em regra, não quer dizer nada, ou quase nada”. Esse defeito do poeta seria decorrente de sua "pobreza de vocabulário", que se fazia acompanhar da sua "miséria de ideias":

Os 31 sonetos do Sr. Saturnino de Meireles só têm um direito à admiração: é ver como ele os fez, todos, com meia dúzia de palavras: triste, tristeza, flor, florir, florescer, rosas, lírios, mistério, branco, vago, essência, rosas, espiritual... Arrumando esses termos de vários modos, ele obteve em poesia o trabalho desses jogos de paciência, que consistem em dispor diversamente, mas com simetria, vários pedacinhos de mosaico.

Em 19 de março de 1898, seis dias após ${ }^{10}$ a morte do autor de Missal, J. dos Santos registrava na sua "Crônica literária" a ocorrência de "um grande movimento em torno do nome de Cruz e Sousa", sobre quem haveria um "desencontro de opiniões". A título de homenagem póstuma, o crítico transcreveu texto por ele publicado em 1893 sobre Broquéis que haveria recebido "a sanção do próprio poeta”. Segundo seu depoimento, Cruz e Sousa haveria ido à redação do jornal ${ }^{11}$ adquirir cem exemplares do número com a apreciação de seu livro. Mais tarde, J. dos Santos soubera do próprio poeta que seu objetivo fora inserir a crítica nos volumes que entregaria a diversos amigos. Cruz e Sousa teria também declarado que "concordava com ela nas suas linhas gerais, sendo até então a que mais lhe agradara". Logo em suas primeiras linhas, o texto já revelava o teor geral da avaliação de Broquéis e dos livros póstumos

10 Note-se que o crítico aproveitou a primeira publicação de sua coluna para pronunciar-se sobre o poeta recentemente falecido.

11 Tratava-se de O Tempo, no qual o crítico respondia pelas "Notas de João Bocó”. 
de Cruz e Sousa publicados do início da coluna "Crônica literária" em 1897 até 1905, quando saíram à luz os Últimos sonetos:

É um livro delicioso. Da primeira à última estrofe vai-se embalado numa cadência de frases e rimas, que deleita o ouvido. Em compensação, não há dentro dele uma só ideia. É sonoro e oco.

Ora, se, depois disto, eu lhes dissesse que gosto do volume, parecer-lhes-ia troça. E não é. Os senhores mesmos hão de ler e hão de gostar. Exige-se apenas um requisito: "que saibam ler".

Para o crítico, os versos de Broquéis eram "pura música - e unicamente música" sem artifícios, sem "desfalecimentos de método": "O sentimento musical predomina de tal maneira que, instintivamente, os seus versos vão encontrando todos os recursos necessários para adquirir a intensidade precisa de ritmo".

Tais recursos seriam a abundância de palavras esdrúxulas (proparoxítonas) e a escolha de rimas e sílabas tônicas que recaem em "i" e"a".

No entanto, a musicalidade quase espontânea haveria resultado em desprezo pela significação das palavras; se "tão extravagante acidente" ocorresse - a significação das palavras -, o poeta não teria "mérito nem responsabilidade" por ele. Por isso, J. dos Santos formula uma recomendação:

Que, porém, o leitor não analise cousa alguma. Leia em voz alta, como merecem ser lidos todos estes versos. Enquanto se for embalando na cadência, no ritmo, ao desdobrar harmonioso dos versos, passar-lhe-ão pelo espírito evocações fugaces, [sic] de mil cousas formosíssimas.

A publicação de Faróis foi noticiada pela "Crônica literária" em 27 de agosto de 1900. O texto iniciou-se com a constatação de que Cruz e Sousa era um escritor julgado: "julgado mal por uns, julgado inigualável e sublime por outros". No novo livro, encontrar-se- 
-iam "os mesmos defeitos e as mesmas belezas dos Broquéis", que seriam, respectivamente, a falta de significação das palavras e a musicalidade dos versos: "O ritmo, que ele busca, é sempre simplíssimo. Vai, como uma cadência de tã-tã, ${ }^{12}$ martelando as sílabas fortes. Pouco importa que essas sílabas estejam em palavras, que não vêm a propósito de nada. O essencial é que elas estalem, gritem, soem fortemente".

A apreciação de Faróis permitiu a J. dos Santos formular uma nova restrição a Cruz e Sousa. Tendo assegurado a superioridade dos seus versos sobre a prosa poética de Missal e Evocações, o crítico apontou, entretanto, o que seria um defeito fundamental do poeta:

... a forma metrificada [...] tinha para Cruz e Sousa a vantagem de reprimir um pouco a sua incontinência de palavras. A limitação das sílabas do verso forçava-o a isto. Nos Broquéis o mal não era tão evidente, porque, mais apertado ainda no cárcere estreito do soneto, ele não podia alongar-se excessivamente.

Um grande número de poesias dos Faróis são simples enumerações, que se podiam esticar de um modo indefinido.

Após demonstrar com exemplos a prática das enumerações e de, mais uma vez, denunciar a falta de significação dos versos do poeta simbolista, J. dos Santos encerra a resenha ironicamente: "Cruz e Sousa está hoje na moda entre alguns dos nossos novos, que até mesmo consideram esse sonhador romântico como um precursor de novos caminhos. Ilusões desta natureza são frequentes na história de todas as literaturas..."

Em 13 de outubro de 1905, a "Crônica literária" foi toda dedicada aos Últimos sonetos, de Cruz e Sousa. A leitura dos poemas "Grandeza oculta" e "O assinalado" levou J. dos Santos a concluir que o poeta considerava-se "um eleito, um predestinado":

12 Não se adota aqui a forma dicionarizada tantã porque a forma tan-tan, que se encontra no jornal, é provavelmente uma onomatopeia. 
... ele não tinha dúvida alguma de que estava fazendo coisas "imortais", "belezas eternas". Esse orgulho íntimo, em um rapaz que viveu pobre e morreu moço, e que, embora tendo esse elevado conceito de si mesmo, não o deixava transparecer no convívio social, longe de ser antipático, é atraente.

Segundo o crítico, saber dessa disposição de espírito inclinava o público a procurar na obra do poeta "os vestígios desse gênio, de que ele se julgava tão alta encarnação”. Tal inclinação seria então reforçada pelas demonstrações do "culto piedoso de que alguns amigos cercaram sua memória”. Entre esses amigos, destacava-se Nestor Vítor, que J. dos Santos (maldosamente?) lembrou ser o organizador do volume recém-lançado. Por tudo isso, o crítico declarou haver iniciado a leitura dos Últimos sonetos "com cuidado e simpatia" e "disposto a mudar de opinião acerca de Cruz e Sousa”. No entanto, sua avaliação foi mais uma vez negativa: "Positivamente, não há nessas poesias nada de novo, nada de elevado e sublime. Todas as suas produções se caracterizam pela harmonia do verso, mas é uma harmonia obtida com sacrifício do sentido”.

J. dos Santos ficou provavelmente satisfeito com a constância de seu julgamento. No prólogo "A crítica literária", que abre as suas Páginas de crítica, Medeiros e Albuquerque apontou como grande qualidade do crítico a definição de critérios e permanência do ponto de vista. Justamente por essa razão criticou seu mestre Sílvio Romero, que considerava Cruz e Sousa "um metrificador sonoro e oco, quase absolutamente destituído de ideias", mas mudou radicalmente de opinião ao conhecer pessoalmente o gentil poeta e testemunhar a vida difícil que levava (Albuquerque, 1920, p.8).

A resenha de Últimos sonetos acrescentou mais uma restrição às formuladas nos outros textos já mencionados. Nela J. dos Santos transcreveu 46 versos em que haveria repetição de palavras. Eis alguns exemplos dados por ele: "E chegaste ao saber de altos saberes"; "Dos compassivos és o compassivo"; "São lama sempre e sempre serão lama”. Depois de lembrar que "os cantos primitivos dos povos mais rudes se caracterizavam pela repetição", afirmou 
que quando Cruz e Sousa "quer reforçar a expressão de uma ideia, repete. Repete, a todo propósito. Repete, sem propósito nenhum. Repete infatigavelmente". A resenha encerra-se com a costumeira ironia: "no conjunto, os Últimos sonetos são exatamente do gênero dos Faróis e dos Broquéis. Os que apreciavam estes dois primeiros livros, apreciarão o último. Os outros continuarão a não entender" (Santo, 1905, p.3).

Valorizando o mot juste, combatendo os adjetivos supérfluos e o "pernosticismo" das palavras raras, recomendando o emprego dos metros tradicionais e de rimas simples mais variadas, J. dos Santos não poderia aceitar as ousadias simbolistas como o verso mais fluente (sem as cesuras convencionais), a repetição de palavras-chave como místico e lírio, os substantivos transformados em símbolos mediante o uso de iniciais maiúsculas, o hermetismo voluntário, o anseio pela transcendência e a espiritualidade difusa. Causa entretanto certo pasmo que o antigo admirador de Verlaine e Mallarmé demonstrasse tanta prevenção contra o Simbolismo brasileiro e evitasse analisá-lo segundo os próprios pressupostos do movimento, os quais certamente não ignorava, haja vista o conhecimento atualizado da poesia francesa que suas resenhas revelavam. O que impressiona ainda mais é o sarcasmo e a contundência de suas apreciações críticas. $\mathrm{O}$ ateísmo publicamente assumido ${ }^{13}$ talvez contribuísse para que recusasse liminarmente o espiritualismo simbolista, assim como o seu cientificismo talvez impedisse de aceitar os enunciados imprecisos e as imagens extravagantes dos novos.

No caso específico de Cruz e Sousa, poeta de maior envergadura, o crítico parece haver empregado a estratégia de circunscrever o reconhecimento do seu talento exclusivamente ao âmbito da musicalidade dos versos para que pudesse imediatamente neutralizar essa qualidade positiva com a enfática e insistente acusação de

13 Segundo confessa em Quando eu era vivo..., sua descrença seria resultado de repetidas e meditadas leituras de Força e matéria (1855), de Ludwig Büchner, e de Blasfêmias (1884), de Jean Richepin (Albuquerque, 1942, p.46-7). 
falta de significação de seus poemas. Esse tratamento conferido ao Dante Negro, além do já mencionado sarcasmo contra os poetas novos, sugere que talvez houvesse da parte do crítico J. dos Santos o propósito consciente e talvez programático de sufocar as manifestações do Simbolismo no Brasil. 


\section{8 \\ O jovem Paulo Barreto E OS SIMBOLISTAS ${ }^{1}$}

A Cidade do Rio foi criada para ser uma arma de combate em prol da abolição da escravatura. José do Patrocínio, ${ }^{2}$ seu diretor e principal redator, escolheu a data de 28 de setembro de 1887 para o lançamento do primeiro número como homenagem evidente à Lei do Ventre Livre, que naquele dia completava dezesseis anos de vigência. Pouco tempo durou a luta, pois, como se sabe, em 13 de maio de 1888 a princesa Isabel assinou a assim chamada Lei Áurea. Após a realização de seu grande objetivo, Patrocínio provavelmente perdeu o norte. Republicano convicto até 1888 , o jornalista passou então a

1 A Benedito Antunes dedica-se a nova publicação deste artigo, já divulgado em 2010 no volume 31 da revista Itinerários, de Araraquara.

2 Patrocínio iniciou sua carreira jornalística na Gazeta de Notícias em 1877, logo se destacando pela cobertura da terrível seca que afetou o Ceará naquele ano. Em 1881, tornou insustentável a sua permanência no jornal por desagradar aos poderosos comerciantes portugueses ao criticar, em seus artigos, a concentração de propriedades nas mãos de estrangeiros. Após a demissão, recorreu ao sogro, Emiliano Rosa de Sena, para adquirir parte da combalida Gazeta da Tarde, cujo diretor, Ferreira de Meneses, morrera naquele ano. Dirigido por Patrocínio até 1887, esse jornal destacou-se pela combatividade, sofrendo, inclusive, frequentes ameaças de empastelamento. Em primeiro de setembro de 1887, o jornalista rompeu com seu sócio, Luís Ferreira de Moura Brito, que não se sentia muito à vontade com o radicalismo e as incertezas financeiras vividas pelo jornal (cf. Magalhães Jr., 1969, p.60-70, 116-24 e 221). 
apoiar a Monarquia; entretanto, com o golpe militar de 15 de novembro de 1889 já em andamento, Patrocínio "proclamou a República” na Câmara Municipal do Rio de Janeiro (Magalhães Jr., 1969, p.280-8). Com o advento do regime republicano, passou, segundo as más-línguas, a alugar a sua pena para as causas mais compensadoras.

No final do século XIX, o jornal de José do Patrocínio passava por sérias dificuldades financeiras ${ }^{3}$ e não podia oferecer salários e condições de trabalho atraentes para jornalistas experimentados. ${ }^{4}$ Assim, proporcionava oportunidades para estreantes como Paulo Barreto, ${ }^{5}$ que posteriormente seria mais conhecido pelo pseudônimo de João do Rio. Patrocínio deixou a cargo do novo colaborador a crítica de teatro, literatura e artes plásticas. Em artigo comemorativo do décimo-terceiro aniversário da folha, Barreto qualificou-a de "flâmula do início de individualidades literárias"; segundo ele, na Cidade do Rio sempre havia "pelas colunas, pelas mesas, pela casa inteira, a vibração da mocidade corajosa e forte, a juventude eterna" (Barreto, 1900 [3 ago. 1899], p.2).

Parte de uma ampla pesquisa sobre a repercussão do Simbolismo nos jornais diários cariocas, este ensaio procura revelar como as obras simbolistas e seus autores foram recebidos pelo jovem colaborador do jornal de Patrocínio.

Paulo Barreto utilizou pela primeira vez o pseudônimo Claude na Cidade do Rio em 3 de agosto de 1899, dois dias antes de comple-

3 Uma nota publicada na Cidade do Rio em 6 de setembro de 1901 tratava abertamente da crise por que passava o jornal, com perdas de redatores e com dificuldades de manter em funcionamento as oficinas. Nesse momento difícil, o sólido Jornal de Comércio colocou generosamente à disposição da Cidade do Rio os funcionários de seu setor gráfico e o seu estoque de papel.

4 Sob o comando de Demerval da Fonseca, integravam a redação Batista Coelho, Paulo Barreto, Victor Viana, Paes de Figueiredo, A. Pinheiro, Gabriel Pinheiro, Cordoville, Raul Xavier e Caldeira Filho (cf. Cidade do Rio, 1900, p.3).

5 As primícias de Paulo Barreto seriam colhidas pelo jornal A Tribuna, dirigido por Alcindo Guanabara. Renato Cordeiro Gomes afirma que a colaboração de Paulo Barreto na Cidade do Rio encerrou-se em outubro de 1900. No entanto, ainda o escritor viria a publicar textos no jornal de Patrocínio em 10 e 11 de setembro de 1901 (cf. Gomes, 2005, p.45). 
tar dezoito anos, para assinar uma resenha de Terra dolorosa, livro de contos de Oliveira Gomes (Claude, 3 ago. 1899, p.1). Como Émile Zola adotara o mesmo pseudônimo em sua coluna no jornal L'Evénement, na qual defendera os pintores impressionistas em 1866, a utilização de Claude por Paulo Barreto representava provavelmente uma reverência ao aclamado autor francês.

Claude iniciou seu texto reconhecendo que o autor, identificado como um dos líderes simbolistas, "editou o seu livro preciosamente com uma capa lembrando missais", mas logo afirmou que o artifício não passava de "uma imitação das edições do Mercúrio de França, fonte centralizadora da decadência espiritual latina". Ao tratar do estilo do autor, o crítico não foi menos impiedoso: "São quase nevroses aquelas frases cheias de reticências com uma porção de palavras começando por letras maiúsculas”. Terra dolorosa discreparia, segundo o crítico, da positividade científica do século XIX:

Quando, em plena Europa no começo deste século, a cruzada de uma arte forte, que fosse a vida, propagou-se por uma dezena de grandes homens, quando o experimentalismo surge com Claude Bernard e Chevreul fundando um método novo da positividade; quando Comte fez uma enciclopédia tremenda de saber, reformando toda a matemática, fundando a lei dos três estados, e Darwin, um desdobramento de Lyell e Lamarck, demonstra o evolucionismo e a seleção; os cérebros impotentes para pensar, atacados de uma degeneração mental, trazem à publicidade pedaços esparsos da sua pobreza cerebral, trapos dolorosos da decadência de uma raça, revivendo a sensualidade mórbida de Salomão, a decrepitude romântica. (ibidem)

Claude encerrou o seu texto com ironia feroz, negando a existência de qualquer valor intrínseco no livro:

... como um exemplo frisante da incapacidade avassaladora, como um caso especial da nevrose geral que ataca sempre os de pouca 
positividade científica ou os obcecados, guarda-se o livro. Como novidade de escola, personalidade artística nova dando um gérmen mais de vida a essa ressurreição, é banalíssimo, terrivelmente banal. (ibidem)

Na Cidade do Rio, o crítico Paulo Barreto ainda examinou livros de românticos retardatários e de parnasianos, mas na resenha dos Cantos, de J. H. de Freitas, publicada em 4 de setembro de 1899, revelou que seu ideal de poesia ainda não se realizara, apesar do brilho fugaz dos primeiros parnasianos:

O Parnasianismo, única forma de verso aceitável, desde que ainda não houve poeta capaz de nos dar o verdadeiro naturalismo, ora pecando pela exageração com Richepin, ora pela timidez com Coppée; nunca ficam perfeitamente estabelecidos aqui, estiolando-se naqueles mesmos que a aclimaram - a arte teve um momento de elegância do verso, de qualquer cousa de fino, rápido e brusco, como um fogo de vistas: a aclimação dos delírios de Catulle Mendes e Banville, sendo a geração de 1880 a única que se pode orgulhar disso. (idem, 4 set. 1899, p.2)

Munido desses conceitos, Paulo Barreto dedicou ao Simbolismo em 3 de outubro de 1899 todo um artigo, que assinou com seu próprio nome. Logo no início lamentou que, no século da ciência e da filosofia positivista, a humanidade se inclinasse "com todo o peso das convicções tradicionais e hereditárias para o ocultismo da crendice e o simbolismo artístico, grito da ignorância ou da degeneração". Da sua perspectiva, o contexto era desastroso:

... a divagação simbólica e desencontrada assoberba todo o mundo vagarosa como um pântano formado pelas chuvas hibernais, pantanoso como o leito dos rios em vazante, triste de uma aguda tristeza agonienta [sic] no relincho de uma espécie retrogradando ou de todo um mundo nas convulsões epiléticas da loucura. (Barreto, 1899, p.2) 
O crítico considerava os novos rumos da arte um verdadeiro retrocesso:

Os métodos científicos vão por terra, todo o trabalho de gerações para a obra da verdade, que começa no XVI século, termina aqui bruscamente diante da vara de um mágico ou da gritaria cavernosa do simbolismo; a grande teoria d'arte, que já surgira em Homero, desaparece depois de uma evolução milenária [sic] para a forma final da perfeição. (ibidem)

Paulo Barreto não dirigiu suas farpas exclusivamente aos simbolistas brasileiros; muito pelo contrário, quis pronunciar-se sobre o Simbolismo universal. Assim, atacou os costumes e a toilette dos franceses que se embebedavam nos cafés parisienses:

...fizeram uso das vestimentas originais, andaram mentecaptamente de barba assíria como o Sr. Peladan, fizeram sucessos de reclame [sic] como os vendedores de extratos maus, à custa de chapéus de seda cor de rosa, à custa de casacos velhos como o delicioso e dipsômano Verlaine, que chegou a instituir a moda de fatos verdes, tal era a sua porcaria e a cor transformada das suas vestes. (ibidem)

O crítico insinuou que a extravagância teve o condão de conquistar a "massa" e formar "uma chusma enorme de discípulos ignorantes ou desequilibrados". Suas palavras revelavam até mesmo certa prevenção moralista contra os usos e costumes dos novos artistas:

O burguês comprava o livro de um senhor qualquer original no modo de vestir, ou cheio de vícios contra a natureza. Enquanto um inimigo ao lado, vestido como toda a gente, desmascarava-o, cortando o tumor do vício tranquilo e calmo como um médico, os outros que surgiam usavam cousas esquisitas, embebedavam-se, andavam sujos e cantavam numa apoteose nevrótica, de palavras 
azuis e brancas, todos os vícios proibidos e todas as degenerações. (ibidem) $)^{6}$

Depois de tratar rapidamente da difusão do Simbolismo pela Europa, o crítico da Cidade do Rio considerou - com uma sintaxe impossível, diga-se de passagem - a repercussão do movimento entre os brasileiros:

O Brasil, que já passou pela crise Hugoana, da qual ainda temos exemplos, perdurou, na forma parnasiana, do verso da geração de 80 , e que incapaz foi de dar uma verdadeira impressão do experimentalismo artístico, assimilou pelas condições de degenerência [sic] mental e rudimentar instrução característica, essa escola má e imperfeita sob o apupo alvar da populaça que via mais uns palhaços a diverti-los denominados pela estupidez trágica do burguês genericamente de nefelibatas. (Barreto, 1899, p.2)

Paulo Barreto encerrou o seu artigo declarando-se impressionado com os "vinte anos de poder" dos simbolistas e confessando: "Dá vontade de desfechar em gargalhadas convulsas, ou de desatar em pranto, chorando a humanidade e chorando a verdade". Deve-se observar, no entanto, que o crítico se referia aos franceses, pois o Simbolismo brasileiro ainda não contava dez anos. Para o crítico, os simbolistas vinham "da prostituição mental, da bandalheira gritada alto nas avenidas públicas, do vício afixado nas esquinas, da imoralidade proclamada no altar pseudocasto de uma ignomínia clandestina" (ibidem). Nota-se que o jovem Paulo Barreto, perfeitamente doutrinado pelo Positivismo e munido de concepções cientificistas, não compreendia a força renovadora do Simbolismo, consideran-

6 Paulo Barreto referiu-se a Oscar Wilde como "o louco moral por excelência, invertido vulgar, desequilibrado completo que chamou a atenção do inglês comilão e parvo pelos passeios escandalosos em Pall-Mall-Frant”. João do Rio, como se sabe, teria motivos para identificar-se com o autor a quem dirigia essas palavras tão duras. 
do-o, ao contrário, manifestação retrógrada de tendências obscurantistas, responsáveis pela decadência da civilização ocidental. A arte simbolista seria, de seu ponto de vista, resultado da conjunção de farisaísmo e impostura.

Claude não se restringiu à apreciação crítica de obras simbolistas; a celebração do segundo aniversário da morte de Cruz e Sousa deu-lhe oportunidade de ridicularizar os próprios simbolistas remanescentes, que cultivavam com carinho a memória do Dante Negro.

Em 19 de março de 1900, a Cidade do Rio anunciava para a noite dois eventos em homenagem a Cruz e Sousa. No Liceu de Artes e Ofícios, haveria "festival" organizado por Francisco Bittencourt Félix, Rafael Pinheiro Colatino Barroso e Batista Coelho. Discursariam Cunha e Costa, secretário do jornal A Imprensa, o poeta Félix Pacheco, Carlos D. Fernandes, redator de A Imprensa, a escritora e jornalista espanhola Eva Canel, Félix Bocaiúva e o escritor Colatino Barroso. Na Associação Cristã de Moços, a celebração ocorreria por conta da revista literária A Vida; nela discursariam Nestor Vitor, Gustavo Santiago, Deodato Maia, Neto Machado, V. Coaracy e Oliveira Gomes. Castro Meneses, Holanda Cunha e Norberto Guerra declamariam poemas em homenagem ao poeta morto.

No dia seguinte, o jornal noticiava a realização dos eventos de forma breve e insípida. No entanto, em 23 de março iniciava-se a publicação em três partes de um relato pormenorizado da primeira cerimônia feito por Claude, que fora ao Liceu em companhia de seu amigo André, correspondente de um jornal de São Paulo. Com isso, a Cidade do Rio acolhia a primeira reportagem de Paulo Barreto, que cultivaria o gênero com brilho por anos a fio. Algumas de suas melhores produções podem ser apreciadas, por exemplo, no livro A alma encantadora das ruas (1908). Em setembro e outubro de 1900, Claude ainda publicaria reportagens sobre exposição de artes plásticas da Escola Nacional de Belas Artes. Nessa oportunidade, André, esse interlocutor privilegiado de Claude, seria um dos alunos da instituição. As reportagens sairiam publicadas sob a epígrafe "O salão de 1900", mas o subtítulo do segundo texto já deixava 
clara a apreciação do crítico: "A mediocridade expositora" (Claude, 13 set. 1900, p.2).

Logo no início de sua reportagem, Claude declarava haver encontrado, quando estava a caminho, na companhia de André, com um "literato" que garantia não se realizar a cerimônia do Liceu e tentava conduzi-los à Associação Cristã de Moços. Claude logo concluiu tratar-se de um pérfido estratagema para "roubar público" do Liceu. Real ou inventado, o episódio servia para tornar evidente a divisão (e a confusão) existente nos arraiais simbolistas, pois os grupos de admiradores do Dante Negro não conseguiam unir-se nem mesmo para celebrar a memória do grande ídolo comum.

Já no salão do Liceu, os dois amigos, Claude e André, observaram meticulosamente os participantes do evento. Cunha e Costa foi descrito como um "moço com muito óleo no cabelo, de andar grave, pausado". Félix Pacheco apresentava uma "face biliosa" e, em uma homenagem póstuma, "parecia acabado de alegria". Colatino Barroso era um "mocinho loiro e vermelho", "chefe da escola simbolista", que manifestava singular "vontade de subir... de aparecer". Saturnino Meireles apresentava-se como "um senhor moreno, extremamente alto, de casaca, magro, de luvas pretas" (idem, 23 mar. 1900, p.2).

Um tanto surpreso, Claude viu André receber de um "senhor gordo" um abraço que foi "convulsivo, extremo, como aqueles dados nas ocasiões solenes da vida, em um dia de aniversário ou na missa de sétimo dia de parente chegado". Logo o correspondente da folha paulista esclareceu tratar-se de "um literato do Paraná, de Curitiba”: era Emiliano Perneta. André também informou que, no sul, a arte simbolista aumentava: "Quantas revistas, meu amigo, quanto jornal, que veneração pelo mestre!” (ibidem).

Após a irônica caracterização dos presentes, Claude empenhou-se em descrever o salão, que estava "ornado de lírios de fazenda branca aos cantos, e de longos festões de flores artificiais ao teto" e dividia-se em três partes. No fundo, junto a um retrato de Cruz e Sousa pintado por Maurício Jubim, postaram-se a comissão organizadora e os oradores em companhia das senhoras presentes. 
Logo depois, em nível mais baixo, reuniram-se os representantes da imprensa e, por fim, posicionou-se a "massa seleta", segundo a expressão de André.

Com o salão já repleto, começaram a surgir manifestações de impaciência com a ausência de Eva Canel. Mas então se apresentou o mestre de cerimônias "de casaca, com a barba muito bem tratada", e portando, note-se bem, um leque. Cunha e Costa era, segundo André, um "talento". No entanto, logo na apresentação dos oradores cometeu uma gafe, justificando a ausência de Félix Pacheco, que estava presente. Quem não havia comparecido fora Félix Bocaiúva. Tratava-se de uma distração desculpável, mas Claude não deixou de registrá-la, provavelmente com o objetivo de destacar uma presuntiva irrelevância ou obscuridade dos convidados.

Primeiro a discursar, Pacheco postou-se na tribuna, que seria, segundo o repórter, "novo púlpito onde pregaria a religião do poeta morto a uma plateia estática". Do alto, o orador "olhou a massa, abotoou-se, desamarrou um rolo de papel, um grosso rolo por sinal; consultou as lentes, e o silêncio caía de chofre na sociedade seleta do Sr. André” (idem).

Quando o discurso mal começava, veio da plateia uma súbita exclamação: "Está aí a Eva Canel”. O orador não pôde prosseguir, pois explodiu uma salva de palmas e a comissão organizadora dirigiu-se toda inteira à porta do salão. Pacheco somente pôde retomar o seu discurso quando a escritora já estava acomodada em sua cadeira. ${ }^{7}$ Note-se que Claude fez do episódio uma cena de comédia e ridicularizou a frustração do orador intempestivamente interrompido. ${ }^{8}$

7 O fim do tumulto deu a Claude ocasião para referir-se a uma frase célebre: “... tudo passa neste mundo, já o disse esse profundo J. de Alencar, talento perpetuado em bronze pelo nosso jornalismo defronte de um hotel, e muito lido no norte" (ibidem). Note-se por esse fragmento a irreverência e a petulância do jovem Paulo Barreto, que não poupava nem mesmo autores consagrados.

8 Até aqui as citações referem-se à primeira parte do artigo, publicada no dia 23 de março de 1900. 
Segundo o cronista da Cidade do Rio, Félix Pacheco discursou com voz esganiçada e, ao final, rouca; sempre que utilizou o francês e o inglês não foi entendido. Sua intervenção haveria denunciado seu "pedantismo de conselheiro querendo passar por um homem tão erudito que só fala condicionalmente". Para expor a pretensiosa parcialidade do orador, Claude transcreveu-lhe as seguintes palavras: "Cruz e Sousa [...] fez mais pela língua portuguesa que todos os passados, Garret, Herculano, Camões e por aí abaixo”. Por fim, Pacheco haveria chamado Zola de "poeta das mulheres estéreis", o que André considerou flagrante desinformação, pois o romancista francês haveria escrito "mil páginas exigindo a fecundidade, cantando-a" (Claude, 24 mar. 1900, p.2). Como se sabe, o jornalista referia-se a Fécondité, de 1899, um dos Quatre Évangiles. ${ }^{9}$

O resumo que Claude apresentou do primeiro discurso poderia parecer elogioso, mas era, como se pode facilmente notar, de uma ironia mordaz:

Entretanto Félix Pacheco esteve esplêndido, verboso, solene, falou nos [sic] mártires da poesia, dos poetas pobres; não citou o clássico português Camões, mas falou de Varela, desse mártir, de Casimiro de Abreu, e acabou recitando pessimamente a conhecida prece de Baudelaire, curvado religiosamente diante do retrato do falecido comemorado; uma prolongada salva de palmas, vibrante, longa, infinita, rasgou de um jato o ar estático, exigiu de novo a sua presença no púlpito, e tudo aquilo tinha qualquer coisa de um bando de peregrinas a louvar do santo milagroso, que o salvou da chaga e da impureza. (idem, 26 de março de 1900, p.3) $)^{10}$

Segundo André, o orador seguinte teria muito talento e seria talvez "mais revolucionário, mais gritador". Quando Carlos Dias Fernandes, com casaca e "o cabelo liso, grande, caindo às vezes

9 Neste parágrafo resume-se a parte publicada em 24 de março de 1900.

10 Esta, assim como as próximas citações, refere-se à terceira e última parte do relato de Claude, publicada em 26 de março de 1900. 
para o rosto”, apresentou-se, Claude observou que o público não o recebeu com as mesmas demonstrações de simpatia dirigidas a Pacheco. Muito provavelmente, nem mesmo o cronista dedicou-lhe muita atenção, pois resumiu sua intervenção em apenas um parágrafo, que satirizava os trejeitos e gestos amaneirados do orador:

...o Sr. Dias Fernandes dizia uns versos laudatórios nada extraordinários, comuns mesmo na voz noturna dos simbolistas de aquém e de além mar, e parecia falar para dentro de um túmulo, com a voz angustiada, levando mecanicamente a mão aos lábios, fechados os dedos em forma de flor, para abri-los no ar, fantasticamente. E em seu modo, modo da escola que é um doido sucesso em Portugal e Paris, dando riso à gente, fez com que muitos dos seus versos se perdessem. Poucos aplausos teve. (ibidem)

Enquanto Eva Canel, terceira oradora e grande sensação da noite, dirigia-se ao púlpito sob entusiásticas aclamações, André recebia de um recém-chegado - "um mocinho implicante, de lentes escuras" -, uma síntese da cerimônia concorrente de Nestor Vítor: "Brigaram com o Teófilo, ${ }^{11}$ já acabou, não falaram para vinte pessoas. Foi um desastre" (ibidem). Observe-se que, embora impedido de comparecer ao segundo evento em homenagem à memória de Cruz e Sousa, Claude não deixou de registrar, de forma um tanto leviana, o seu suposto fracasso em sua reportagem.

Canel iniciou seu discurso desculpando-se com a comissão por não se dispor a elogiar, mas sim a dizer a verdade sobre Cruz e Sousa, a quem, aliás, declarava não conhecer muito bem. Considerando-se fidedigno o relato de Claude, a escritora causou provavelmente muito constrangimento com inoportunas considerações etnológicas. Leia-se, por exemplo, o seguinte trecho:

...julgando-se a filha aspérrima da serrania, única prosaica em meio aos líricos senhores, que cuidaram de sonho, e de arte de palavras,

11 Provável referência a Rodolfo Teófilo. 
traçou com uma fina intuição psicológica o retrato do poeta falecido; fê-lo numa frase memorável, tal o relevo e a retórica empregada: um idiota, abrindo para os que o seguissem o manicômio da literatura pátria; insistiu dolorosamente, brutalmente da condição de raça inferior do autor dos Broquéis, insistiu mais e mais, fez quase o seu tema nesse negror do poeta: foi lógica, bem lógica e no meio daqueles senhores, homens feitos que viviam do sonho e faziam versos, glorificando um outro de quem se não guarda uma frase, porque pelas más condições etimológicas não passou de palavras, em triunfal, amesquinhava a casaca, e dizia de frente num culto de morte, era o que sentia irreverente brutal. (ibidem) ${ }^{12}$

O final do discurso de Eva Canel instalou a confusão no recinto, pois, julgando que Félix Pacheco e Dias Fernandes haviam sido meros "aperitivos", o público "arrastava cadeiras, galopava pelos corredores para espairecer, trocando opiniões, ou recolher a penates" (ibidem).

Como a cerimônia ainda não havia acabado, os organizadores procuravam recolocar ordem no ambiente para que o orador seguinte pudesse ser ouvido. Nesse ínterim, Claude e André foram fumar no corredor, junto à janela, mas sempre atentos à cerimônia. Subira à tribuna um "mocinho loiro, loiro e vermelho": era Colatino Barroso. Claude assim resumiu sua participação:

O poeta, arregalando os olhos como enraivado, fazia soar uma porção de sons que, concatenados, embalaram, tal [sic] os motivos variados, pelos compositores. Como a sua voz era muito aberta, as palavras saíam bem pronunciadas, claras como notas de clarim, mas no fundo de todo aquele emaranhamento de vocábulos, muitos dos quais extemporâneos, impossível era descobrir o que queria o orador, o que sentia o poeta, - ou o que sofria, como se diz em

12 Não se sabe se a estranha sintaxe deve ser atribuída a Paulo Barreto ou aos compositores e revisores da Cidade do Rio, que não eram impecáveis. 
linguagem poético-simbólica, - qual era o fim de toda aquela trapalhada. Bem se supunha às vezes que Colatino chorava a cor preta do falecido Sousa, tão branco por dentro... (ibidem)

Entre cigarros e comentários maldosos com os amigos, Claude ouviu muito distraído as palavras do orador, sendo atraído por elas somente quando Barroso se exaltava dizendo versos retumbantes como estes: "Canhões cuspindo luz! / Pureza luminosa das alturas" (ibidem).

Quando o orador se calou, "o público, farto de discurso, com a incivilidade que o caracteriza, atirou-se à saída”. As pessoas que ainda estavam pacientemente à espera protestaram e Carlos Dias Fernandes procurou chamar de volta os que haviam saído. A plateia, que até então ouvira pacientemente, tornou-se ruidosa, o que foi agravado pelo fato de que o mestre de cerimônias, um tanto incompreensivelmente, passou a falar muito baixo. Ao referir-se amavelmente aos oradores que se haviam apresentado, Cunha e Costa chamou Fernandes de "garrafa de Leide", o que o público entendeu por "garrafa de leite". Daí em diante, a troça e a hilaridade tomaram conta da plateia. Mas convém ressaltar: isso haveria ocorrido sempre segundo o relato de Claude, que assim narrou o fim da cerimônia:

Bruscamente Cunha e Costa, entretanto, parou. A turba galopava pelo corredor, despregava pela escada abaixo, terminava uma comemoração a um morto, grotescamente, às gargalhadas, abandonava o culto, numa exibição caricata de pretensiosos desejos de subir; de poetas indiferentes, de estrangeiros ignorantes da nossa arte de terra nova, a julgar, a decidir de individualidades de literários vazios a vomitar frases, sem que lhe dessem importância, de um homem gentil e moderno, prestando-se por pedido ao cargo de presidente para a galhofa e a risota de um povaréu simbolista! E era aquilo a comemoração ao pobre Cruz e Sousa, um senhor que dizia as suas tolices incompreensivelmente e em frases estranhas! Era aquilo! (ibidem) 
Ao deixar o salão, Claude encontrou-se com André, que ouvia Colatino Barroso. O poeta, muito compungido, lamentava a hilaridade da plateia e fazia reparos ao evento, dizendo que "fora exagerada a comissão, fora exagerada a Eva, fora exagerado o Cunha e Costa, e não havia ninguém que se não tivesse exagerado, exceção feita dele" (ibidem).

Claude haveria recebido tais palavras com uma incontrolável crise de riso; recriminado por André, assim procurou justificar-se:

-Deixe, meu caro André. Não há nada como o riso. Os Goncourt resumiam tudo com duas palavras. Sublime e estúpido; quando a coisa não é sublime, é, necessariamente, estúpida e não há nada que faça rir como a estupidez alheia. Deixa-me rir. Eu rio do Liceu, da comissão, daqueles senhores, da Eva, do escândalo, do Dr. Cunha e Costa, do Sr. Colatino, do público, do pobre coitado do Cruz e Sousa, que está servindo para isso depois de morto... (ibidem)

Não poderia encontrar outro desfecho a reportagem de Paulo Barreto, pois provocar o riso pelo tratamento escarnecedor dedicado à cerimônia fora, desde o início, o seu objetivo. As "gargalhadas convulsas" que ele refreara no artigo sobre o Simbolismo finalmente explodiram com toda força. Escrita com recursos próprios da narrativa literária como a caracterização satírica do espaço e das personagens, a alternância calculada entre cenas e sumários, o emprego do discurso direto para expor as personagens ao ridículo com frases deslocadas do contexto original, a técnica de desprezar os méritos e tornar hiperbólicos os defeitos dos oradores, a criação do interlocutor André, que conhecia o Simbolismo e os simbolistas e dava ao repórter a oportunidade de ostentar uma orgulhosa ignorância a esse respeito, a reportagem de Paulo Barreto não pode ser tomada como expressão da verdade, como pretendia o jovem jornalista, mas deve ser compreendida como um texto rigorosamente planejado para alcançar determinados objetivos.

Embora talvez houvesse inicialmente, da parte da Cidade do Rio, o objetivo de desprestigiar um evento de que participavam 
com destaque Cunha e Costa e Carlos D. Fernandes, redatores do jornal A Imprensa, dirigido por Rui Barbosa, velho desafeto de José do Patrocínio, essa reportagem bastante parcial e mal-intencionada dá bem a medida da verdadeira campanha de descrédito que se dirigiu ao Simbolismo e seus seguidores no Brasil. Há nos periódicos do final do século XIX vários artigos e sátiras extremamente agressivos ou irônicos contra Cruz e Sousa e outros simbolistas.

Esse longo texto iluminava retrospectivamente as críticas literárias de Claude ou Paulo Barreto, pois com a sua leitura conclui-se que as resenhas e o artigo sobre o Simbolismo, aqui comentados, não foram escritos por um observador objetivo, sereno e imparcial, mas por um fervoroso defensor do cientificismo positivista e das lamentáveis concepções etnológicas daquele tempo e apaixonado adversário das doutrinas e obras simbolistas, recusadas por ele sem exame pormenorizado e paciente. 


\section{9 \\ Os ERÓTICOS DIÁRIOS DE Ana Cristina Cesar ${ }^{1}$}

\section{Ana Cristina Cesar e a literatura dos anos 70}

Durante a década de 1970, alguns poetas resolveram imprimir e vender pessoalmente seus próprios livros. A impressão era geralmente feita de forma artesanal, através de offset (nos casos mais sofisticados), cópias xerográficas e, principalmente, cópias mimeografadas, o que deu àqueles poetas o nome de "geração mimeógrafo".

Os autores eram responsáveis pelo aspecto gráfico, seleção de textos e organização do livro, e este, portanto, se tornava a expressão de uma individualidade. Como consequência, os poetas, que exploravam até as possibilidades expressivas da materialidade do objeto livro (livros minúsculos, livros compostos por folhas soltas dentro de um envelope etc.), passaram a gozar de uma maior liberdade, uma vez que não precisavam se dobrar às "razões comerciais" das editoras que, de praxe, se orientam pelo duvidoso "interesse do leitor médio".

A distribuição dos livros também se deu de forma inovadora. O próprio poeta vendia a sua produção à porta dos bares da moda,

1 Publicou-se originalmente este estudo em 1995, no segundo volume da revista Miscelânea. 
cafés, teatros, cinemas etc. Era também muito frequente a doação aos amigos e conhecidos. Dessa forma, a circulação era naturalmente muito restrita, tornando-se hoje impossível rastrear tudo o que se fez no Brasil em termos de produção independente, dificuldade esta sentida pela organizadora da antologia 26 poetas hoje, Heloísa Buarque de Hollanda, que se viu obrigada a considerar apenas a produção independente do Rio de Janeiro por razões práticas (Hollanda, 1976, p.10).

Esses poetas publicaram à margem do tradicional esquema de edição e distribuição feito pelas grandes editoras, cada vez mais capitalizadas e inacessíveis. Por isso, sua poesia ganha o epíteto de "marginal", que a identifica.

É em meio a essa literatura "clandestina" que se forma a poeta de que tratamos aqui: Ana Cristina Cesar. Os textos analisados constam de sua obra mais conhecida, A teus pés, que contém textos anteriormente publicados na forma de pequenos livros, com tiragem reduzidíssima (por volta de quinhentos exemplares). São eles: Cenas de abril, Correspondência completa e Luvas de pelica. Nos fragmentos de diário aqui considerados, procuraremos demonstrar as relações entre os aspectos formais desses textos e a tematização do erotismo feminino.

Ana Cristina também vendia seus próprios livros à porta de cinemas, mas o que a diferencia dos seus contemporâneos é a sua postura crítica frente à literatura que se fazia naquele momento. Seus livros satirizam a sua própria condição de marginais.

Correspondência completa, por exemplo, é um livro minúsculo que menciona a seguinte equipe de realização: projeto gráfico de Heloísa Buarque de Hollanda; assessoria editorial de Armando Freitas Filho; assessoria administrativa de Luis Olavo Fontes; produção gráfica de Cecília Leal de Oliveira e Tania Kacelnik. Um livro tão modesto como esse prescinde com certeza de equipe tão numerosa, e a frase "foi feito o depósito legal" que nele se encontra só se explica como brincadeira. Isso tudo só pode ser entendido como a sátira da poeta à sua condição de marginal, incorporando ironicamente no seu livro características das produções das grandes editoras. 
O gosto pelo autobiográfico, o tom intimista e confessional e a vontade de diminuir a distância entre a arte e a vida, que marcam a literatura dos anos 70, influenciarão a poesia de Ana Cristina Cesar não apenas como fonte temática, mas serão também responsáveis pela adoção de um gênero que se coaduna a eles: o diário íntimo.

Entretanto, o diário de Ana é fingido (embora sejam detectáveis algumas referências reais), e sua confissão é falsa ou mediatizada pela ficção.

Com efeito, Ana Cristina diferencia-se dos seus contemporâneos pela recusa do espontaneísmo e por um melhor relacionamento com a tradição literária, que se reflete no diálogo intertextual com outros poetas.

\section{Caderno terapêutico - a recriação do diário íntimo}

A poesia da geração mimeógrafo busca uma relação de proximidade com o leitor - iniciada com a venda direta - por meio de uma linguagem simplificada, do retorno decidido ao verso, "abolido" pela vanguarda concretista, e do resgate do lirismo e do trivial, que haviam sido expulsos da grande poesia do momento (Cabral e concretos), preocupada com a "construção". Essa proximidade fortalecia-se pela representação do cotidiano, pelo registro de situações fortuitas, no qual o poeta buscava autenticidade e espontaneidade, flagrando a poesia que está presente no dia-a-dia.

Essa poetização do cotidiano evoca certamente Manoel Bandeira (especialmente o de "Maçã" e "Pensão familiar"), mas está o mais das vezes despida de véus metafísicos e busca o belo na imanência das coisas concretas.

A constante busca de autenticidade, espontaneidade, sinceridade e confissão aproxima perigosamente vida e literatura, comprometendo a literariedade dos poemas, pois a literatura é artifício, é recriação artística da realidade.

A preocupação com o cotidiano faz que a poesia marginal adquira um tom de diário íntimo. Em Ana Cristina Cesar, esse interesse 
reflete-se na própria forma dos textos, que ou se transformam em diários ou mantêm um aspecto de notação rápida de acontecimentos do dia-a-dia. Porém, como já notou Flora Süssekind, esses diários são "mentirosos", por não serem anotações autênticas das impressões de Ana, mas pura invenção literária. Como adverte o título de um deles: "Simulacro de uma Solidão" (Cesar, 1991, p.92-3).

Os diários são geralmente cadernos secretos usados para registrar os pensamentos mais íntimos, os medos e ódios mais inconfessáveis, por uma linguagem muito pessoal. O diário íntimo - fiel depositário de tudo o que não se confia às demais pessoas - deve ser protegido contra a curiosidade de qualquer outro que não seja seu autor, que nele está representado fielmente.

Assim, os diários podem servir como um sucedâneo do analista e ser um instrumento de autoanálise, de autoconhecimento, uma vez que, por meio dele, o autor pode perceber os seus limites, seus preconceitos, suas angústias e medos.

Angústia, para Ana Cristina, é "fala entupida" e o remédio é falar tudo, ou melhor, "escrever como quem fala tudo" (em "10.01.82", ibidem) e usar o diário como "caderno terapêutico" (expressão utilizada muitas vezes por Ana Cristina). Segundo Maria Lúcia de Barros Camargo (1990, p.270), "o diário pode ser o espelho em que o eu, vendo a si mesmo na dialética entre o fora e o dentro, vai constituir sua própria imagem".

Para criar os seus cadernos terapêuticos, Ana Cristina faz uso do diário enquanto gênero literário. Assim, o "eu” que se expressa por meio deles é uma criação ficcional. Da mesma forma, toda impressão de espontaneidade e autenticidade causada no leitor é um efeito estilisticamente calculado, como assinala Maria L. B. Camargo:

Nos "simulados de diário", a sintaxe é entrecortada. Frases curtas, muitas vezes nominais, mimetizando o caráter fragmentário do próprio gênero. Nesse descontínuo, a reflexão simultânea sobre o ato de escrever e sobre o eu que se escreve. Este eu que se espelha em sua escrita, e traz para ela os reflexos de outras falas. (ibidem, p.247, grifos nossos) 
Com o esforço de mimetizar a linguagem do diário, Ana Cristina usa e abusa da elipse, espalhando espaços em branco pelo texto, que devem ser preenchidos pelo leitor. Este procedimento é inovador na literatura brasileira, "tão acostumada à dicção oratória e à redundância que sua resposta aos vetos autoritários poucas vezes passou por um 'procedimento menos' [...], pela elipse e por uma paixão pela lacuna, pelo texto em suspenso, hesitante..." (Süssekind, 1985, p.66).

Por meio desse laconismo, a poeta finge o segredo e o leitor sente como "natural" o seu desconhecimento dos referentes, uma vez que tem a consciência de lidar com um texto privado que não se destina, em princípio, à leitura pública.

Essa questão da privacidade nos faz pensar a respeito da opção de Ana Cristina pelos gêneros confessionais: a carta e o diário. A poeta faz um uso paródico deles, explorando suas possibilidades expressivas de forma não canônica, ou seja, privilegiando apenas seus aspectos formais. Ela se beneficia, por exemplo, da oscilação de forma e de estilo, que lhe dá liberdade de criar um texto mais orgânico, com coerência entre as frases, como "Arpejos", e outro mais fragmentário e hermético, como "Guia Semanal de Ideias".

Outro problema suscitado pelo "simulacro de diário" é a posição de Ana Cristina frente à tradição literária. Nesse sentido, o primeiro aspecto que nos salta aos olhos é a impossibilidade de dizer se o que lemos é prosa ou poesia. A disposição gráfica em parágrafos é de prosa, mas o tratamento da linguagem, que explora todas as suas possibilidades expressivas, é de poesia.

$\mathrm{Na}$ verdade, a poeta não opta por nenhum dos polos, mas caminha gostosamente pelos interstícios. Além disso, ela transcende a celeuma iniciada pelos concretistas sobre o fim do verso: embora não faça dele um uso clássico, os seus textos beneficiam-se do ritmo e de outros recursos próprios da versificação tradicional.

Efetivamente, os diários de Ana Cristina fazem uma mistura (moderníssima, diga-se de passagem) entre prosa e poesia, entre narração e dissertação, entre lirismo e realismo.

Outro ponto importante a esclarecer é sobre a identidade do “eu” que se expressa pelos diários. Quem escreve não é propria- 
mente Ana Cristina, pois os textos são ficcionais e a autora deles é uma criação literária. Essa entidade, prima do conhecido eu poético, nós a chamaremos de Autora.

As cartas e os diários de Ana Cristina fazem a crítica do intimismo confessional dos seus contemporâneos da geração mimeógrafo, que escrevem num tom de carta, diário e depoimento, mas não transformam essa tendência em determinante da forma dos textos. Ana Cristina encontrou o gênero adequado para os temas de sua época.

Dentro de uma perspectiva mais ampla, os textos de Ana Cristina, com sua verdade biográfica disfarçada ou sua intimidade fingida, nos fazem refletir sobre os limites - muitas vezes tênues - entre vida e literatura, entre ficção e confissão, colocando em xeque questões como a literariedade (ou sua falta) do texto e o próprio estatuto da literatura.

\section{O erotismo feminino nos diários}

Uma questão muito interessante suscitada pelo gênero diário íntimo é sobre o tipo de leitura que ele requer: pode ser lido exclusivamente como ficção ou ser considerado uma confissão pura. Mas acreditamos que o melhor é ler mesclando essas duas possibilidades.

Aquele que lê o diário como confissão pensa estar às voltas com segredos autobiográficos e sente o prazer de devassar uma intimidade, de violar a privacidade de alguém. Como nota Caio Fernando Abreu, "Ana C. concede ao leitor aquele delicioso prazer meio proibido de espiar a intimidade alheia pelo buraco da fechadura" (em Cesar, 1992, contracapa) - prazer de voyeur, que se excita por ver e não ser visto.

Na nossa análise dos diários de Ana C. César, daremos maior atenção àqueles que ofereçam ao leitor algum registro de atividade erótica. Nesses casos, o interesse voyeurístico intensifica-se e o prazer de violar uma intimidade é maior. Por um lado, o leitor delicia-se em montar um perfil da vida erótica da Autora, por meio das 
pistas - muitas vezes discretíssimas - que foram espalhadas pelo texto (aparentemente de forma involuntária).

Por outro lado, o leitor que trata os diários como pura ficção tende a considerar a personagem que se vai delineando nos diários uma mera criação literária. Assim, o comportamento erótico dessa personagem é visto como um componente harmônico de um todo.

Esses dois perfis de leitores parecem ajustar-se com perfeição aos personagens da Correspondência completa, Gil e Mary. O primeiro lê "para desvendar mistérios e faz perguntas capciosas, pensando que cada verso oculta sintomas, segredos biográficos" - é o leitor voyeur. A segunda lê como se tudo fosse "literatura pura, e não entende as referências diretas". Ana Cristina demonstra, portanto, ter consciência de que seu texto comporta ambos os tipos de leitores ao mesmo tempo.

Assim, sentimo-nos autorizados a pensar que a Autora acende uma vela para cada leitor e que o seu texto mistura material autobiográfico e pura invenção. Consideramos possível, portanto, recorrer ao que sabemos da mulher Ana C. para compreender melhor a poeta.

Porém, o que essa consciência sobre a leitura revela de mais importante é que mesmo aquilo que pode ser lido como autobiográfico foi escrito deliberadamente. Desta forma, as argutas conclusões de um leitor como Gil acerca do erotismo da Autora foram em grande parte previstas e/ou desejadas. Ana Cristina estabelece um jogo com o leitor, em que o seu interesse pelo erotismo é satisfeito, mas de forma comedida e elegante.

Nos diários, o tratamento dado ao erotismo é o oposto do que verificamos nos romances de massa, em que há muita vulgaridade e situações-clichê, que esvaziam essas representações de qualquer significado humano mais profundo.

As representações do erotismo nos diários adquirem maior relevância por constituírem um ponto de vista realmente feminino, o que é raro em literatura brasileira.

A título de demonstração da consciência que A. C. Cesar possuía da necessidade de uma escrita feminina, lembramos que, certa 
vez, um auditório basicamente feminino, que se sentira incomodado pelo pseudodiário "Arpejos", com sua referência a uma certa "coceira no hímen", enveredou por uma discussão sobre poesia feminina. Uma senhora da sala disse, então, que Cecília Meireles fazia poesia feminina sem apelar para "aquelas vulgaridades". E Ana Cristina, que estava presente, disparou: "Mas Cecília Meireles é um homem” (cf. Camargo, 1990, p.223-4). Esclarecemos que, para Ana Cristana, a masculinidade de Cecília Meireles diz respeito ao modo como ela vê o mundo feminino e aos aspectos formais de sua poesia, que herda modelos de poetas masculinos.

Ana Cristina, ao contrário, ao recriar uma perspectiva feminina do mundo e, mais especificamente, do erotismo, introduz os gêneros confessionais - a carta e o diário - como a forma adequada para expressar a sua linguagem feminina.

Para deixar de generalidades e tentar comprovar nos textos algumas das afirmações categóricas que fizemos, analisaremos a representação do erotismo (que se quer feminina) nos pseudodiários "Arpejos", "16 de Junho" e "Jornal Íntimo".

\section{A insinuação de homoerotismo em "Arpejos"}

Alguns textos de Ana Cristina não apresentam a principal marca de um diário, que é a menção da data de cada inscrição. No entanto, esses textos não deixam de possuir a característica que realmente define esse gênero, ou seja, ser o registro de sentimentos, impressões e acontecimentos diários.

"Arpejos" (Cesar, 1992, p.66), por exemplo, é um diário sem data, dividido em três fragmentos, numerados por algarismos arábicos, que parecem ser inscrições de uma mesma data. Nessa perspectiva, o fragmento 1 é a notação referente às primeiras horas da manhã, logo após o despertar ("Acordei com coceira no hímen."). O fragmento 2 corresponde a um período posterior do dia, em que a Autora rememora acontecimentos da véspera ("Ontem na recepção...”). O terceiro fragmento teria sido escrito à noite e resume a 
atividade diária ("Passo o dia a recordar..." ) e o passeio de fim de tarde.

O primeiro fragmento inicia com a frase "Acordei com coceira no hímen”, que, logo de início, identifica a Autora como mulher, pela menção a uma parte da anatomia feminina cercada de simbolismo e/ou preconceito. A presença do hímen, como todos sabem, significa que a mulher nunca manteve relações sexuais que resultassem na introdução do pênis na vagina, o que romperia essa membrana. Ou, no caso de um hímen complacente, a membrana indica que a mulher não teve partos normais.

Dessa forma, com a frase citada, a Autora pode ser identificada - por um leitor como Gil - como uma mulher de pouca experiência erótica. Entretanto, o hímen é tratado, no texto, apenas como uma membrana qualquer, que coça e pode ser examinada com espelhinho, sendo despido de qualquer significado simbólico. Mas, na sequência, a Autora reconhece-se inexperiente para avaliar as causas da coceira: "Meus olhos leigos na certa não percebem que um rouge a mais tem significado a mais".

$\mathrm{Na}$ fraseologia erótica brasileira, prurido nos órgãos sexuais significa excitação erótica, o que fica comprovado por expressões correntes (e vulgares) como "fogo no rabo" e similares. Gil não hesitaria em pensar que Ana era presa de situação semelhante. Mas a virginal Autora adota uma solução "cientificista", atacando os sintomas sem se preocupar com as causas: "Passei pomada branca até que a pele (rugosa e murcha) ficasse brilhante".

A seguir surgem palavras com alguma simbologia masculina (fálica): "Arpoador" (aquele que arpoa) e "selim" (pelo formato do objeto e sua proximidade com a genitália feminina). Considerando-se a coceira uma excitação, ela pode ser atribuída ao desejo de entrar em contato com o mundo masculino ("ir à ponta do arpoador").

A mulher inexperiente que não sabe dar respostas adequadas à sua excitação volta-se à leitura. Triste papel da literatura: servir de sucedâneo do erotismo ou, falando linguagem psicanalítica, ser a sublimação de pulsões básicas. Mas não é isso mesmo que o leitor ávido por erotismo busca nos diários? 
Entretanto, o segundo fragmento introduz outra possível causa da "coceira no hímen". Na recepção da véspera, a Autora atrapalhara-se na tradicional troca de dois beijinhos com Antonia, o que pode ter tido dois resultados. A Autora pode ter "virado inadvertidamente a cabeça", evitando o beijo, o que pode explicar que ela tenha sentido na nuca "o bafo seco do susto" - ou pode ter sido beijada em cheio na boca, o que explicaria a constrangedora situação das duas mulheres durante a festa: "Não havia como desfazer o engano. Sorrimos o resto da noite. Falo o tempo todo em mim. Não deixo Antonia abrir sua boca...". Assim, a coceira pode significar o desejo despertado pelo beijo de Antonia. Repare como a boca da amiga atrai a atenção: "Não deixo Antonia abrir sua boca de lagarto beijando para sempre o ar”. Essa hipótese é reforçada pela previsão de uma "crise aguda de remorsos", que parece ser provocada mais pelo beijo convencional da despedida ("de acordo, dos dois lados"), do que pelo equivocado beijo na boca.

O terceiro fragmento inicia-se com a frase "A crise parece controlada". Mas que crise? A de coceira, acalmada pela pomada e a sublimação via leitura? Ou a de remorsos, índice de um homoerotismo latente?

A Autora passa o dia rememorando a cena do beijo em frente ao espelho, imitando-se a si própria (sequiosa) e a Antonia, procurando nela "signos de decepção", que não encontra, pois até esse simulacro de Antonia "continuaria inexorável".

Então, a Autora dá o projetado passeio: "Saio depois de tantos ensaios". É interessante que "ensaios" pode referir-se tanto às micagens em frente ao espelho quanto ao gênero que foi objeto de leitura. Seria essa ambiguidade mais um índice da função da literatura de sublimação das pulsões eróticas?

A excitação mesma só diminui com o exercício físico: "O movimento das rodas me desanuvia os tendões duros". Essa atividade é praticada como fuga. O corpo, responsável pela crise, com seus desejos interditos, deve ser exigido até que se acalme: "Pedalo de maneira insensata". Tal como os religiosos medievais, a Autora "açoita" o corpo para livrar-se do desejo pecaminoso. 
Se lermos como Mary, que ignora as referências diretas, consideraremos "Arpejos" uma tentativa de representação textual do homoerotismo feminino que, nesse caso, é vivido por apenas uma personagem de forma ocasional e conflitante. Homoerotismo não compartilhado, vivido na solidão, cujas únicas testemunhas são as folhas do diário. Dizendo de outro modo: a literatura é o canal usado para desafogar a angústia causada pelo desejo insatisfeito. $\mathrm{O}$ diário é, de fato, "caderno terapêutico".

\section{As relações triangulares do "Jornal Íntimo"}

Ao contrário de "Arpejos", o texto "Jornal Íntimo" (Cesar, 1992, p.80-1) apresenta a clássica organização do diário: inscrições iniciadas por datas. Essas datas apresentam, porém, algumas características notáveis, como omissão da referência ao ano e ordem aparentemente aleatória.

O efeito da referida omissão é dar ao diário um aspecto de intemporalidade, que o denuncia como literatura pura: uma data precisa pressuporia algum vínculo com a realidade histórica.

Já a desordem das datas convida-nos a duas leituras diferentes. Uma delas respeita a aleatoriedade - porém, que explicações daremos a ela: "desatenção" de Ana Cristina ou resultado de anotações feitas em anos diferentes? Outra leitura possível é a que recoloca os fragmentos em ordem cronológica.

Não acreditando na gratuidade da desordem de datas, preferimos tentar encontrar uma razão para ela, porque, como diz o próprio texto, "Não basta produzir contradições, é preciso explicá-las". O que parece haver de comum entre os segmentos é a presença de algumas reflexões sobre a criação literária.

Em “30 de Junho", por exemplo, a Autora anota a frase citada acima, que diz a estar preocupando. Produzir contradições e ao mesmo tempo explicá-las é uma opção que coloca em risco o texto que se quer literatura, uma vez que esta muitas vezes se alimenta de 
ambiguidades, elipses e imprecisão de significados: as explicações quem as dá, na medida de suas possibilidades, é o leitor.

Em “29 de Junho”, a Autora registra sua festa de aniversário, em que lê trechos do antigo diário. Um ouvinte especial - um diplomata - comenta: "Que bela alegriazinha adolescente", comentário que deve equivaler, dentro da polidez diplomática, a uma acusação de puerilidade e insignificância, à qual a Autora reage infantilmente, "deitando no chão sem calças". Esse trecho reflete a situação dos gêneros confessionais - diário e carta - normalmente considerados menores e pouco prestigiados.

Em "27 de Junho", a Autora anota: "Datilografei até sentir câimbras. Seriam culpas suaves. Binder diz que o diário é um artifício, que não sou sincera porque desejo secretamente que o leiam". Neste trecho, vemos a literatura proposta como atividade impulsiva e perturbadora (dois primeiros períodos), ou seja, expressão autêntica de uma individualidade. Porém, logo em seguida, temos a opinião de Binder, que considera o diário um artifício, um texto criado para ser lido por outros. Temos, então, novamente representada a tensão, que sempre se estabelece nos textos de Ana Cristina, entre ficção e confissão. Embora possam conter verdades biográficas, os diários são "mentirosos".

"26 de Junho" traz a opinião de Binder e Célia sobre o estilo da Autora nas reuniões, que pode ser um disfarce para falar do estilo dos diários. Para Célia, é ambíguo e sobrecarregado, com excessos gratuitos (de qual natureza?). Binder acha que é mera sedução. A Autora, entretanto, ignora completamente a questão: "Os dois discutem como gatos enquanto rumbas me sacolejam" - talvez porque ambos tenham razão.

Em "25 de Junho", a exemplo de "Arpejos", a Autora novamente é vítima de prurido, originado desta vez de uma urticária. Essa perturbação física está também associada à literatura, pois surge após ela ter acabado "O Jardim de Caminhos que se Bifurcam” (é objeto de leitura, tradução ou criação?).

Em "27 de Junho", o prurido é curado com literatura: a cópia datilográfica de Escola de mulheres. Ana Cristina parece lembrar que esse prurido, causado e aliviado dessa forma, também é literatura. 
Em "28 de Junho", Binder viola a privacidade do diário após uma briga com a Autora, escrevendo algumas palavras - palavrões "de vadia para baixo" - como reação ao que encontra escrito. Fica mais uma vez demonstrada a consciência de Ana Cristina de que o leitor de diários busca verdades biográficas - que podem chocá-lo.

Portanto, tomando as inscrições da forma como se apresentam, lemos "Jornal Íntimo" como um texto metalinguístico que aborda questões como a literariedade, o valor do gênero diário íntimo e o tipo de leitura que exige e as relações entre ficção e confissão questões fundamentais na obra de Ana Cristina.

Mesmo a leitura dos fragmentos na ordem em que estão chama a atenção para a referência explícita a uma relação sexual da Autora com Binder. Porém, essa relação passa a primeiro plano se tentarmos colocar os fragmentos em ordem cronológica. E notaremos então que o erotismo desse diário não se restringe a ela, complicando-se com a presença de Célia e configurando uma relação triangular, em que a Autora se vê dividida entre um homem e uma mulher.

Assim, o texto começaria com "25 de Junho", em que a Autora se diz vítima de urticária. Binder - o homem - não alivia a coceira da Autora: "Binder me afaga sempre no lugar errado". Ele não entende a linguagem do seu corpo.

O fragmento "26 de Junho" introduz Célia - a mulher - que passa a disputar espaço na vida da Autora com Binder: "Os dois discutem como gatos enquanto rumbas me sacolejam”.

Existem três notações de "27 de Junho", que podem se referir perfeitamente a três períodos diferentes do mesmo dia. Penso que a primeira seria a iniciada por "O prurido só passou com a datilografia”. Nela vemos que a coceira que o homem não soube resolver se desfaz pelo contato com o mundo feminino, por meio da cópia de Escola de mulheres, com que a Autora se identifica, pois afinal foram "trinta páginas no original sem errar".

A segunda notação é iniciada por "Célia sonhou que eu a espancava até quebrar os dentes". Esse "espancamento”, em linguagem onírica, pode ter um significado interessante, pois sabemos, graças a Bataille, as relações que o erotismo mantém com a violência. $\mathrm{O}$ 
relato do sonho pode ter perturbado a Autora: "Passei a tarde toda obnubilada".

A terceira e última notação é o relato do primeiro ato sexual entre a Autora e Binder. As coisas não foram muito harmoniosas: "O obscurecimento me perseguiu outra vez. Não consegui fazer as reclamações devidas". Isso se dá porque o homem não consegue entender a linguagem erótica da Autora: "Recitei a propósito fantasias capilares, descabelos, pelos subindo pelo pescoço. Quando Binder perguntou do banheiro o que eu dizia respondi 'Nada' funebremente".

Logo no dia seguinte, "28 de Junho”, há entre Binder e a Autora uma melodramática discussão.

Agora, para falar de "29 de Junho", precisamos discutir a questão da coesão textual, que está bem trabalhada em "Arpejos", em que cada frase está harmonicamente ligada às anteriores, por meio dos mecanismos de coesão, como por exemplo, substituição nominal, conjunção, coesão lexical etc. Em "Jornal Íntimo" esses mecanismos são pouco explorados. Cada frase parece ser independente das outras, o que recupera a ideia de que o diário é um texto que só faz sentido completo para o seu autor.

Ana Cristina, como vimos, mimetiza a sintaxe entrecortada e as frases curtas, muitas vezes nominais, que são características do gênero. Dessa forma, as frases podem ser o registro de acontecimentos diversos que não mantêm necessariamente relação entre si.

Assim, podemos ler, em "29 de Junho", o segmento - "Me deitei no chão sem calças. Ouvi a palavra dissipação nos gordos dentes de Célia" - como independente da cena da leitura do diário. Perguntamo-nos em que situação estaria ela sem calças acompanhada de Célia.

A frase que orientou nossa primeira leitura ("Não basta...") aparece agora no final, em que a contradição é a hesitação da Autora entre Binder e Célia, o homem e a mulher. Nas duas notações de 30 de junho, Célia está absoluta na vida da Autora. As duas mulheres gozam de intimidade, espontaneidade e harmonia: "Célia desceu as escadas de quatro. Insisti no despropósito do ato. Comemos outra 
vez aquela ave no almoço. Fungo e suspiro antes de deitar" - harmonia que interrompe até a escrita do diário, que é truncada em "Voltei ao".

Esse diário, com sua dúplice leitura, fala de duas relações triangulares e conflitantes. A primeira estabelece-se entre Autora, leitor e texto. A segunda, entre a Autora, um homem e uma mulher relação conflituosa em que o homoerotismo vence em virtude da grande distância que separa a Autora do mundo masculino.

\section{"16 de Junho" - a independência do erotismo feminino}

A primeira frase de "16 de Junho" (Cesar, 1992, p.72) - "Posso ouvir minha voz feminina: estou cansada de ser homem” - é surpreendente por ser escrita por uma mulher. Supõe-se que também possa existir, na Autora, uma voz masculina e, mais que isso, representa o protesto de uma mulher contra um processo de masculinização, que estaria violentando sua natureza (voz feminina).

Ousamos entender esta influência da masculinidade sobre o universo feminino como consequência inevitável da relação entre os sexos culturalmente estabelecida. Cada sexo tem um papel a representar no intercâmbio erótico. Os comportamentos-padrão não são opostos entre si, mas complementares. O objetivo final dessa interação é a conjunção carnal, que visa, inclusive, à reprodução da espécie.

Assim, o comportamento-padrão feminino não é puro e independente do masculino, mas se define na sua interação com ele. Essa interdependência foi muito bem percebida por Bataille (1987, p.122-3), como demonstram suas palavras citadas a seguir:

Em princípio, um homem pode tanto ser o objeto do desejo de uma mulher, quanto uma mulher ser o objeto de desejo de um homem. Entretanto, o passo inicial da vida sexual é mais frequentemente a procura de uma mulher por um homem. Se os homens 
têm a iniciativa, as mulheres têm o poder de provocar-lhes o desejo. Seria injustificado dizer das mulheres que elas são mais belas, ou mesmo mais desejáveis que os homens. Mas, em sua atitude passiva, elas tentam obter, suscitando o desejo, a conjunção à qual os homens chegam, perseguindo-as. Elas não são mais desejáveis, mas se propõem ao desejo.

Elas se propõem como objetos ao desejo agressivo dos homens.

Bataille entende que até as atitudes mais tradicionalmente femininas, como a faceirice, a preocupação com a beleza do corpo, as atitudes provocantes - em suma, a sedução -, só se definem enquanto desencadeadores do comportamento masculino - o ímpeto de copular com o objeto de desejo.

Portanto, a voz feminina da Autora, que se diz cansada de ser homem, pode estar, na verdade, insatisfeita com o papel erótico que é reservado à mulher. Ela é homem na medida em que existe como contrapartida do desejo masculino: a masculinidade a determina.

Como essa voz feminina quer se libertar do universo masculino, a Autora deve, então, saber desejar de uma forma inovadora, exclusivamente feminina e independente do erotismo masculino. Esse novo erotismo deve, provavelmente, ser vivido entre mulheres.

Porém, "Ângela nega pelos olhos" - não corresponde ao convite proibido. Por isso a Autora, que se quer totalmente mulher, nada mais é que "a woman left lonely".

Essa mudança da Autora não é livre de angústias, pois os comportamentos eróticos alternativos são objeto de uma série de interdições.

Sabemos que Ana Cristina teve formação religiosa e que a instituição mais repressora do erotismo, responsável por grande parte das interdições que o cercam, é, sem dúvida, a Religião. Assim, é natural que a opção erótica esboçada entre em choque com as interdições cristãs.

A Autora vinga-se das interdições com um olhar dessacralizador sobre as coisas de religião. A citação bíblica "Vinde meninos, vinde a Jesus", em um contexto de desejo insatisfeito, perde todo 
significado original. Para quê esse Jesus quer esses angelicais meninos (quase femininos), com "A Bíblia e o hinário no colinho. Meia branca"? Qual o papel da frase "órgão que papai tocava”? (Cesar, 1992, grifo nosso)

A irreverência com a religião manifesta-se também no trocadilho (virtual) entre "reverendíssimo" e "reviradíssima no beliche solteiro". O desejo insatisfeito faz a Autora revirar-se na cama de solteiro.

A Família é outra instituição repressora. Ela deve "vigiar" o comportamento erótico de seus membros. Pensamos que, em "16 de Junho", ela é representada pela mãe, que "veio cheirar e percebeu tudo”. A mãe, como mulher, sabe compreender a perturbação da filha, mas esta não abre mão de sua opção: "Mãe vê dentro dos olhos do coração mas estou cansada de ser homem".

Então a Autora lembra-se do seu novo objeto de desejo, que lhe suscita emoções fortes (trancos). "Angela me dá trancos com os olhos pintados de lilás ou da outra cor sinistra da caixinha." Interessante é que esse objeto se distancia igualmente do padrão erótico feminino de preocupação com a beleza (tradicional), pois Ângela pinta seus olhos com cores sinistras.

A opção por um novo comportamento é tão angustiante que a tensão psíquica se somatiza: "Os peitos andam empedrados. / Disfunções. Frio nos pés".

Mas apesar de todos os conflitos, a Autora fortalece-se em sua opção: "Eu sou o caminho, a verdade, a vida". A voz feminina é ouvida: "Lâmpada para os meus pés é a tua palavra. E luz para o meu caminho". Note-se que a Autora prossegue fazendo pastiche do texto bíblico e o diário termina como uma oração.

\section{A escrita feminina de Ana Cristina Cesar}

A Autora de A teus pés faz do diário íntimo um gênero literário fecundamente expressivo: faz ficção do que é por natureza biográfico e finge serem suas as confissões que são, na verdade, de uma 
personagem ficcional, a Autora. Fica, assim, muito tênue a distinção entre o real e o imaginário.

Para dar uma aura de autenticidade aos diários, Ana Cristina usa uma linguagem adequada ao gênero, com frases curtas, muitas vezes nominais, que mantêm uma fraca coesão entre si. Como consequência, seus textos são lacunares, elípticos e têm uma referencialidade muito vaga.

A elipse abre espaço para uma maior participação do leitor, que, como vimos, pode tomar duas atitudes. Uma delas é considerar os diários a expressão da mulher Ana Cristina. A outra é considerar o diário "mera" literatura.

De qualquer forma, o diário é um instrumento de autoanálise, isto é, o caderno terapêutico que alivia as angústias e a sensação de solidão da Autora.

Nos diários que lemos, a angústia é gerada pelo choque entre uma vivência erótica não convencional e as interdições que se opõe à plena assunção dela. Vimos o quanto instituições repressoras como a Igreja e a Família colaboram no processo de "diabolização" do erotismo.

O homoerotismo dos diários alerta-nos sobre o grau de distanciamento entre os universos masculino e feminino e a dificuldade de homens e mulheres manterem um diálogo satisfatório. Mas o mais importante é que os diários apontam a possibilidade de comportamentos eróticos alternativos, que exacerbam o erotismo enquanto fato de cultura, distanciando-o ainda mais da sexualidade animal.

O homoerotismo é uma das pequenas vitórias que o homo sapiens obtém sobre o seu substrato animal, na eterna guerra contra os limites impostos pela natureza. Não se trata de fazer aqui uma apologia do homoerotismo, ou muito menos patologizá-lo, como pode parecer; apenas o denunciamos como fato de cultura.

Ao contrário de Gil, não nos interessa saber se Ana Cristina Cesar era ou não homossexual para sentirmos o prazer de flagrar seu segredo. Basta-nos apreciar a grande sensibilidade da poeta em relação ao homoerotismo, o que enriquece nossa experiência humana. 
Como vimos, Ana Cristina trabalha com a postura do leitor de diários íntimos, que busca verdades biográficas ou observa a construção da intimidade de uma personagem. Para favorecer a participação desse leitor e também para criar uma atmosfera de segredo e privacidade, ela se utiliza da elipse e não trabalha com referentes muito nítidos. O esforço desse leitor para decifrar o segredo e violar a intimidade da Autora, esforço por meio do qual ele obtém prazer estético, assemelha-se de muitas formas ao comportamento erótico masculino, impetuoso e agressivo, que vê o seu oposto apenas como uma pequena resistência a ser vencida - de preferência com uma certa violência (de natureza simbólica ou ritualística), para o prazer ser maior.

Como correspondente dessa atitude masculina por parte do leitor, temos a escrita de Ana Cristina, que se faz feminina. O uso da elipse abre espaço para a penetração do devassador olhar do leitor olhar fálico. O texto parece estar passivamente à espera, ou melhor, ansioso por ser violado e provoca e estimula o interesse do leitor ao prometer toda a intimidade da Autora.

Porém, essa passividade é tão fingida quanto os diários. Como vimos, as pistas para o leitor são conscientemente espalhadas por Ana Cristina. O ímpeto masculino é, portanto, um mero resultado calculadamente desejado e previsto pela Autora. Quem é a caça? E o caçador?

Paradoxalmente, a relação entre o leitor e os textos que tratam do homoerotismo é semelhante ao comportamento heterossexual mais comum.

Para finalizar, podemos dizer que os "simulacros de diário" são radicalmente femininos, por tratarem de problemas femininos, serem escritos numa linguagem feminina e exigirem, como contrapartida, uma atitude viril do leitor. 


\section{0 \\ Menalton Braff para jovens ${ }^{1}$}

\section{Três narrativas juvenis?}

Parece evidente que o tratamento editorial conferido a um texto interfere na leitura que dele se faz. No caso da literatura infanto-juvenil, formatos, capas, ilustrações, fontes e diagramação predispõem a determinados tipos de expectativas por parte do leitor. Da obra de Menalton Braff, quatro títulos foram editados de modo a atrair o público infanto-juvenil e, principalmente, identificar essas publicações como pertencentes à modalidade. Para as crianças, destinou-se a breve mas encantadora narrativa intitulada Gambito. Para os adolescentes ou jovens, propôs-se a leitura de A esperança por um fio, Como peixe no aquário e Antes da meia-noite.

Menalton Braff nasceu em Taquara (RS) em 1938, passou a adolescência e a juventude em Porto Alegre, mas se viu obrigado a deixar a capital gaúcha em 1965 para pôr-se fora do alcance da repressão da ditadura militar instaurada no ano anterior. Viveu de-

1 Publicou-se primeira versão deste ensaio na coletânea Narrativas juvenis: Geração 2000 (São Paulo: Cultura Acadêmica, 2012), organizada por Alice Áurea Penteado Martha, Vera Teixeira de Aguiar e João Luís Ceccantini, a quem se dedica esta nova edição. 
pois em São Paulo, onde se formou em Letras, tornou-se professor de literatura e fez a sua estreia literária com um romance e um livro de contos em 1984, quando já contava 46 anos. ${ }^{2}$ Em 2000, recebeu o prestigioso prêmio Jabuti por À sombra do cipreste, livro de contos publicado no ano anterior.

O que se pretende examinar aqui é a hipótese de que Janela aberta, primeiro romance de Braff, que o assinou com o pseudônimo de Salvador dos Passos (nome do seu bisavô), pode ser considerado, a despeito da capa circunspecta e do tratamento gráfico convencional, uma narrativa juvenil. Não obstante o que se disse logo de início, as análises aqui desenvolvidas partem do princípio de que a caracterização de um texto deve ser essencialmente determinada por seu conteúdo intrínseco.

Reconhecidas pelo próprio autor como obras juvenis, o qual assim as apresenta em seu site (www.menalton.com.br), Como peixe no aquário (2004), A esperança por um fio (2003) e Antes da meia-noite (2007) constituem o gabarito pelo qual se examina Janela aberta.

\section{Tudo termina bem}

Ao contrário do que ocorre nos sombrios contos e romances para adultos, ${ }^{3}$ nas narrativas juvenis de Menalton Braff o final é sempre (mais ou menos) feliz.

Em Como peixe no aquário, Rita de Cássia, que era balconista de uma papelaria, apropria-se do dinheiro da venda de três cartuchos de tinta para impressora com a expectativa de poder logo devolver a importância ao caixa. No entanto, obrigada a arcar com incontornáveis despesas da família, passa quase cinco meses atormentada

2 Braff vive hoje em Serrana, cidade próxima a Ribeirão Preto.

3 A esse respeito, pode-se mencionar os romances Que enchente me carrega (2000), Castelos de papel (2002), Na teia do sol (2004) e os contos de A coleira no pescoço (2006). 
por remorsos e pelo medo de ser acusada do roubo até poder, enfim, repor o dinheiro e superar definitivamente o problema.

A vida de Artur, o protagonista de A esperança por um fio, muda repentinamente de maneira radical. Seu pai, arrimo de família, sofre um aneurisma e permanece em coma por cerca de oito meses. Por isso, sem outra fonte de renda que não fossem as comissões do pai, que era representante comercial de três empresas, Artur e a mãe deixam São Paulo e mudam-se para o interior, onde podiam contar com o amparo de Leonardo, tio de Artur. O rapaz perde o computador, a casa em que vivia, os amigos e, por escolha própria, a escola e os projetos de curso universitário. Embora profundo, seu sofrimento foi relativamente breve, pois o pai recupera-se de modo pleno após uma cirurgia decisiva.

Os problemas de Aline em Antes da meia-noite não são tão graves. Tratava-se de controlar a compulsão por conversas com amigos virtuais em chats e no MSN para evitar nova reprovação escolar. Assim como, segundo Machado de Assis, a personagem Juliana salva o interesse do romance O primo Basílio (1878), de Eça de Queiroz, os assaltantes da agência em que trabalha a mãe de Aline emprestam à narrativa de Braff a tensão e o interesse que lhe faltam. Findo o assalto e libertada a mãe, que ficara refém por algumas horas, Aline pôde fazer para si mesma promessas de dedicar-se mais seriamente aos estudos e até mesmo entender-se com o namorado da mãe. Entretanto, reforçando ainda mais o caráter secundário do episódio do assalto, a moça controla sua obsessão pela internet utilizando... a internet. No chat ela conhece um certo Fabrício, com quem mantém conversas proveitosas sobre... literatura. Fazendo um uso nobre da tecnologia, Aline descobre que antes perdia muito tempo com bobagens. Comprova-se assim o velho lema da homeopatia: similia similibus curantur.

Em Janela aberta, a família de Raimundo passa por profunda crise em decorrência do desemprego do chefe de família. Edu, o filho mais novo, é obrigado a trabalhar aos doze anos. Laura, a filha mais velha, que já era operária, sente-se coagida pelo pai a aceitar a corte do vizinho Altino para casar-se com ele. Após áspera discus- 
são com o pai, Laura é por ele espancada e jura vingança. $\mathrm{O}$ modo que escolhe para vingar-se é especialmente irônico: sair furtivamente de casa à noite, pulando a janela, para entregar-se justamente a Altino, certa de que o escândalo viria à tona. Como Laura calculara, Raimundo e Iara, sua mãe, sentem profundamente o golpe quando sabem dos vizinhos a respeito das suas fugas noturnas. Quando tudo parecia indicar o completo esfacelamento da família, Raimundo volta a empregar-se e Laura aceita finalmente casar-se com o amante, recebendo então a bênção dos pais.

As experiências das personagens são fortemente condicionadas pelas circunstâncias históricas e sociais em Janela aberta e Como peixe no aquário. Raimundo e seus filhos são afetados pelo desemprego estrutural determinado pela automação industrial. Já Rita de Cássia sofre os efeitos da inviabilidade econômica das pequenas propriedades rurais: o sítio dos pais não podia assegurar o seu sustento e o de seus irmãos. Tentar a sorte na cidade era a única alternativa de sobrevivência viável. Embora a vida de Artur em A esperança por um fio seja, a princípio, alterada por um acontecimento fortuito - a doença do pai -, sua breve experiência de provedor do lar revela o contexto socioeconômico contemporâneo. Como se nota, essas narrativas de Menalton Braff apresentam uma característica importante do Realismo moderno sério, que representa o homem "engastado numa realidade político-socioeconômica de conjunto concreta e em constante evolução" (Auerbach, 1998, p.414).

\section{Soluções formais}

Como peixe no aquário divide-se em quatro partes e um epílogo. Cada parte, por sua vez, divide-se por número variável de capítulos numerados. A primeira parte apresenta dezesseis capítulos, a segunda, oito, a terceira, dez e a quarta, apenas três. O epílogo intitulado "Enfim" não contém subdivisões. No interior dos capítulos, transcrevem-se anotações que Rita de Cássia faz em seu diário. 
Essas manifestações de subjetividade da protagonista muitas vezes apenas repetem o que já fora revelado pelo narrador onisciente.

A estrutura de A esperança por um fio é comparativamente mais simples, pois a narrativa divide-se em 24 capítulos. Entretanto, o narrador-protagonista conta a sua história conservando os verbos no presente. Dessa forma, a morte ou a recuperação do pai de Artur mantêm-se até o final como desenlaces possíveis e ignorados pelo narrador, deixando a vida da personagem em estado de suspensão. O livro apresenta-se fartamente ilustrado e os capítulos são sempre precedidos por uma mesma vinheta que representa a fotografia de um homem acompanhado de um menino.

Antes da meia-noite apresenta-se convencionalmente em dezenove capítulos e a narração repete a fórmula de A esperança por um fio, mas com menor eficácia, pois o desconhecimento da verdadeira identidade do amigo virtual de Aline não tem o mesmo peso da indefinição do destino do pai de Artur.

Em Janela aberta, Braff optou por um tradicional narrador onisciente, mas dividiu a narrativa em duas partes divididas por inúmeros fragmentos não numerados. Nesse romance, emprega-se uma técnica muito interessante, que é a não observância da cronologia dos fatos narrados, de modo que o relato de fatos anteriores fica intercalado à narração de fatos mais recentes. Dado o caráter sistemático e intrincado dessa intercalação, não se pode comparar essa técnica com o emprego tradicional do flashback. No final da primeira parte (Passos, 1984, p.60), por exemplo, intercala-se o relato da discussão de Laura com o ex-namorado Dario com o do espancamento da jovem por Raimundo, sugerindo a elucidação do estado de espírito e das motivações profundas da personagem quando afronta o pai.

Com menor brilho, Braff procurou reeditar a técnica em Antes da meia-noite. De todo modo, a referida intercalação impõe uma leitura mais atenta da narrativa para que se reordenem cronologicamente os episódios. As ações e reações das personagens vão sendo iluminadas pela recuperação de episódios anteriores. Das quatro narrativas, Antes da meia-noite foi a que recebeu um trata- 
mento gráfico mais ousado, com títulos e palavras, expressões ou frases importantes destacados com a utilização da cor vermelha, que também é empregada em detalhes das várias ilustrações. Seis páginas são totalmente vermelhas: nelas as letras são impressas na cor branca. Inserem-se também alguns quadros de fundo rosa que procuram imitar telas de computador.

\section{Sentimento de orfandade}

Nas quatro narrativas aqui estudadas, os jovens ou adolescentes padecem de um acentuado sentimento de abandono ou orfandade e são expostos precocemente aos graves desafios da vida adulta. Rita de Cássia mora longe dos pais, com os quais se comunica apenas por cartas. Deles não recebe o conforto e o amparo de que precisa, mas reiterados pedidos de auxílio e queixas sobre as dificuldades da vida. Artur perde repentinamente a companhia do pai, seu maior amigo, e passa a viver somente com a mãe, com quem, a princípio, não se entende. Aline vive apenas com a mãe, que se divorciara de seu pai. D. Ivone, a mãe, quis estudar e conquistar autonomia, mas o marido não aceitou que sua mulher ganhasse mais. Laura e Edu descobrem que o pai é incapaz de garantir o sustento da família e que a mãe não tem forças para contrariar ou questionar o pai.

Os melhores retratos da adolescência desamparada encontram-se justamente em Janela aberta. Laura é subitamente atirada à vida adulta:

Bela idade, catorze anos! Laura não sabia disso quando saiu de casa naquela manhã. Tinha então catorze anos. Saiu cabisbaixa e pela primeira vez queimou sem medo os riscos da amarelinha. Usava a saia azul-marinho do uniforme, já meio curta, deixando à mostra os joelhos ossudos e um princípio de coxas descarnadas. Primeiro dia de serviço, desamparo maior que primeiro dia de aula. O pai mal empregado, ganhando pouco mais que o salário-mínimo, a vida muito apertada, o jeito era trabalhar. [...] Mesmo de posse da 
Carteira Profissional, ela ainda achava que poderia prolongar sua infância. O serviço de casa, a escola, os cuidados com o Edu, a brincadeira na rua. A verdade somente a penetrou, de forma aguda e até o fundo, quando baixou a alavanca e ouviu o tinir do relógio-ponto. Fim. Acabaram-se as correrias, terminaram-se as brincadeiras, adeus sonho de continuar estudando. (Passos, 1984, p.15)

A menina-moça fica irremediavelmente exposta a um mundo que não prima pela delicadeza: “...o aperto no corredor do ônibus, o bodum inevitável e o esfregar-se indecente dos que, mesmo naquele aperto, conseguiam alguma vantagem" (ibidem, p.16). Cada jornada de trabalho era para ela um verdadeiro suplício: "Voltava para casa com a sensação de ter sido violada, de estar imunda" (ibidem, p.44).

Edu, o irmão de Laura, começa a trabalhar em uma indústria com apenas doze anos, o que o deixa à mercê dos maltratos de um colega de trabalho mais velho e de um ambiente insalubre: "Era um galpão escuro, coberto por uma poeira preta e fina" (ibidem, p.73). O menino suporta tudo porque sente um grande peso sobre os ombros: "Chegou a pensar em pedir a conta. A lembrança do pai saindo de casa todos os dias com aquela cara de desânimo, batendo perna para cima e para baixo, sem nada conseguir, dava-lhe um sentido incômodo de responsabilidade. Aguentava" (ibidem, p.74).

Quando a vingança de Laura abala a família, o sentimento de desamparo em Edu torna-se ainda mais forte: "Os laços, que lhe haviam sempre parecido tão firmes, e que formavam aquela unidade dentro da qual se sentia seguro, esfarelavam-se" (ibidem, p.89).

\section{Rebeldes com ou sem causa}

Com exceção de Rita de Cássia, que carrega a sua cruz sem protestar, os jovens e adolescentes de Menalton Braff têm sempre uma queixa ou uma acusação na ponta da língua. Artur, por exemplo, "odeia" a aparente insensibilidade da mãe e não compreende o seu 
comportamento, como confessa à adorável prima Marília: “...não me entra na cabeça que uma esposa veja o marido assim, morre não morre, e continue fazendo tudo como se ele tivesse saído pra visitar um cliente" (Braff, 2003, p.27). Obrigado pelas circunstâncias a trabalhar, planeja atingir a mãe com uma firme recusa de continuar os estudos: "Tenho de trabalhar? [...] Trabalho, sim. Mas o meu futuro acabou aqui. Vou dizer tudo isso e, dependendo do que ela disser, digo ainda muito mais. Acabou escola, acabou futebol, amizades que mal iniciavam. Vou ser operário do meu tiozinho querido" (ibidem, p.86).

Embora sua cota de sacrifício fosse desprezível, Aline opõe-se à tentativa da mãe de encontrar um novo companheiro. Cria situações embaraçosas para Sérgio, o namorado da mãe, protesta contra as "longas" ausências dela e chega a chantageá-la: "...a senhora não implica mais com a internet e eu largo de implicar com o Sérgio" (ibidem, p.51).

Entretanto, quem melhor encarna a rebeldia juvenil contra o mundo dos adultos é Laura, que mantém áspera discussão com o pai pouco depois de ser ameaçada de espancamento pelo ex-namorado Dario, que a deixara sem explicações e voltara "para buscá-la" dois anos depois. Quando o pai, preocupado com o futuro dela, tenta convencê-la de que Altino, o vizinho, era o melhor marido com quem podia sonhar, Laura reage com uma grande ofensa: "Pois se o senhor tá tão interessado assim no Altino, por que não vai lá dar o rabo pra ele?” (Passos, 1984, p.67).

Duramente espancada pelo pai e possivelmente salva da morte por intervenção dos vizinhos, já que a mãe assistia a tudo impotente, Laura jura vingança: "Amanhã vocês dois vão ver só - pensou ninguém bate injustamente na Laura sem sofrer as consequências" (ibidem, p.14). Ao entregar-se a Altino clandestinamente, procura atingir o pai naquilo que lhe era mais caro: a honorabilidade.

Como Laura friamente planejara, o pai sofre muito com sua atitude e mais abatido fica quando, ao cobrar satisfações de Altino, vem a saber dele que Laura já não era virgem na noite em que o procurou pela primeira vez: 
As posições praticamente invertidas. Apanhado em falta querendo empurrar mercadoria falsificada. Não sabia disso. Nunca pudera imaginar. Então o caso já ficava diferente. Era o máximo da vergonha, aquela última revelação. Nem ódio mais conseguiria arrancar de seu vazio. De tal forma arrasado ficou o pai, que Laura se condoeu. Culpa e vitória misturadas. (ibidem, p.107)

\section{Despreparados para a vida}

Arrimos de família, rebeldes ou petulantes, os jovens e adolescentes de Menalton Braff revelam-se, entretanto, despreparados para enfrentar autonomamente os desafios da vida adulta. Rita de Cássia, por exemplo, é interpelada por um desconhecido quando estava no ponto de ônibus ao final de uma tarde. Aceita a carona que lhe é oferecida, satisfeita com a possibilidade de voltar para casa no conforto de um automóvel. Quem a alerta para os riscos a que se expunha com a atitude é Elaine, sua amiga: "-Você é bem pastel mesmo Rita. Um Norberto abre a porta do carro e você vai entrando, é isso?" (Braff, 2004, p.102). Depois de receber essa admoestação, Rita de Cássia escapa por pouco de sofrer um estupro. Norberto era, na verdade, Walter Garcia da Silva, um homem casado que se especializara em perseguir jovenzinhas.

A imaturidade de Artur fica evidente em sua decisão de deixar a escola simplesmente para mostrar-se insatisfeito com a necessidade de trabalhar. Quem o chama à razão é Tadeu, um colega de trabalho que fora aprovado em vestibular da Unesp de Franca:

- Você é um bosta, Artur. Você acha que eu comecei a trabalhar quando? Na sétima série já fui estudar à noite pra ajudar em casa. E passei sem Cursinho, cara. Sabe por quê? Botei na minha cabeça que pra melhorar de vida ou virava bandido ou me formava. Como não tenho vocação nenhuma pra ser bandido, resolvi me formar. (idem, 2003, p.119) 
Aline desfila em trajes sumários diante do namorado da mãe para constrangê-lo. Repreendida pouco depois pela mãe, procura retorquir de forma provocativa: "...aqui é a minha casa e eu ando do jeito que eu quiser”. A mãe reage de modo a não deixar dúvidas: "Olhe aqui, menininha. Este apartamento é meu, e sou eu quem dita as normas por aqui” (idem, 2007, p.33).

Quando Aline marca um encontro com o namorado virtual, é a vez de sua amiga Carol alertá-la: “- Mas você é louca, Aline. Você não sabe quem é o cara, não sabe nada dele, como é que embarca numa canoa dessa, garota?" (ibidem, p.91).

Muito imatura é também Laura, que se entrega a um homem que, a princípio, não amava, expondo-se às críticas e represálias da sociedade e a uma gravidez indesejada, apenas para vingar-se do pai.

\section{Adultos desamparados}

A despeito da ênfase na perspectiva e na experiência de jovens e adolescentes, as quatro narrativas aqui analisadas acabam por revelar as limitações, os medos e as angústias dos adultos, que estão ainda mais intensamente expostos a um mundo ameaçador.

Em Como peixe no aquário, os pais de Rita de Cássia precisam manter o sítio em funcionamento sem o trabalho indispensável de Tadeu, o filho que ainda vivia com eles, que estava momentaneamente incapacitado para o trabalho por haver contraído erisipela. Na cidade, Eduardo, o irmão mais velho de Rita de Cássia, precisa encontrar emprego para sustentar a família e poder dispensar a irmã de colaborar com o dinheiro do aluguel.

A mãe de Artur, que parecia tão insensível para ele, procura na verdade mostrar-se forte para poupá-lo de preocupações e angústias e para dar a entender que controla a situação extremamente adversa. O ponto alto de A esperança por um fio é o capítulo 16, em que se relata o momento em que Artur descobre os verdadeiros sentimentos da mãe, que sentia saudades do marido e temia o futuro, mas nunca se manifestava a esse respeito para não alarmar ou compungir o filho. 
Em Antes da meia-noite, a mãe de Aline torna-se vítima da violência urbana, ficando sob a mira de um revólver e sofrendo agressões.

Porém, de todos os adultos, o mais desamparado, o mais incapaz de reagir às dificuldades e de administrar a própria vida é Raimundo, o pai de família de Janela aberta. Morando em uma casa humilde, não dispõe de privacidade, pois havia, coladas à sua, outras casas que compartilhavam o mesmo terreno. Sem receber um salário digno, não consegue pagar as prestações de um aparelho de televisão, única fonte de diversão da família, e, portanto, não pode prescindir do auxílio financeiro dos filhos. Quando fica desempregado aos 46 anos, não encontra alternativas para prover a família do estritamente necessário.

\section{Choque de gerações}

Em narrativas destinadas ao público juvenil, um tema que necessariamente se impõe é o do distanciamento entre as gerações a que pertencem pais e filhos; estes tendem a recusar os valores que aqueles defendem. Além disso, os filhos, em processo de autoafirmação, procuram adotar comportamentos que desafiam os padrões éticos e morais recomendados ou mesmo impostos pelos pais.

Em Antes da meia-noite, D. Ivone pergunta à filha se estava namorando Gabriel, com quem trocara vários beijos em seu baile de formatura do Ensino Fundamental. A resposta foi esclarecedora:"Mãezinha, pelo amor de Deus, que papo mais careta! A gente só ficou naquela noite, mais nada" (Braff, 2007, p.22). Depois, quando a mãe chama a atenção de Aline para o fato de que já era tarde para estar à frente do computador, recebe resposta um pouco menos carinhosa: "- A senhora não percebe que está ficando velha e intolerante?" (ibidem, p.28).

Se assim reagem os fartos, o que esperar da pobre e desamparada Laura? Quando falta ao trabalho por estar incomodada com a menarca, Raimundo recrimina-a: "eu trabalhei sete anos numa firma só e não faltei nem no dia de registrar o teu irmão." O comentário foi "curto e grosso": "E de que adiantou?" (Passos, 1984, p.16). 
Deve-se convir que seria difícil para o operário encontrar uma boa resposta para a inoportuna pergunta formulada pela filha. Quando o assunto era o sucesso de pessoas desonestas ou inescrupulosas, "Raimundo argumentava que o melhor de tudo é ter a cabeça erguida. E o sapato furado, completava Laura” (ibidem, p.18).

\section{A força do amor}

Do que ficou exposto, pode-se concluir que Menalton Braff procura em suas narrativas juvenis denunciar a falta de compreensão mútua entre pais e filhos. Estes, por egocentrismo, imaturidade e/ou desinformação, não têm consciência plena dos graves problemas e responsabilidades associados à vida adulta. ${ }^{4}$ Aqueles mantêm os filhos na ignorância de certos fatos para poupá-los ou por não reconhecê-los como interlocutores, embora se vejam obrigados pelas circunstâncias a solicitar deles uma cooperação financeira vital.

Apesar das rusgas mais ou menos intensas e das sérias ameaças que pairam sobre as famílias, pais e filhos acabam por entender-se, pois há uma força poderosa a uni-los: o amor.

Em A esperança por um fio, Artur, depois que "descobre" os verdadeiros sentimentos da mãe, trata-a com uma grande amiga e estabelece com ela relação de cumplicidade. ${ }^{5}$

4 A esse respeito, é bastante eloquente um trecho de Janela aberta em que o narrador ressalta o estado de espírito de Raimundo quando recebe o insulto de Laura. De manhã, o operário fora ao banco para deixar a guia para saque do FGTS. Suas dúvidas e desconfianças diante dos funcionários lembram as reações de Fabiano diante do patrão ou das autoridades policiais em Vidas secas, de Graciliano Ramos. Ressaltando a falta de comunicação entre as personagens, observa o narrador: "Se Laura soubesse o que seu pai sofrera desde a manhã, bem de manhã, teria agido de forma diferente. Se ela pudesse imaginar a sensação de desvalimento que Raimundo tivera ao entrar no banco, então estaria dormindo, agora, sem maiores preocupações” (Passos, 1984, p.60).

5 Certa vez, tia Rute opinou que julgava "dinheiro jogado fora" manter o pai de Artur vivo com aparelhos "sem ter esperança nenhuma”. Artur respondeu agressivamente: "A senhora não tem [esperança] porque a senhora só pensa no 
Aline e a mãe em Antes da meia-noite terminam sempre suas discussões abraçadas e chorando. Sérgio, o namorado, passa a ser aceito por Aline quando o assalto proporciona a ele a oportunidade de mostrar a sinceridade de seu sentimento por D. Ivone. A mãe, aliás, tranquiliza definitivamente a filha egocêntrica quando diz: " Você acha que existe alguma força no mundo capaz de me separar de você?” (Braff, 2007, p.108).

Reza o provérbio que, "em casa onde falta pão, todo mundo grita e ninguém tem razão”. Na casa de Raimundo, com efeito, a dura vida de todos faz prenunciar a completa dissolução da família. Mas Janela aberta tem um final feliz porque Laura, após sentir-se devidamente vingada, procura um pouco canhestramente reconciliar-se com os pais quando lhes solicita autorização para casar-se com Altino. De sua parte, Raimundo e Iara sentem-se felizes por poderem restabelecer um bom relacionamento com a filha, que, afinal, amavam.

\section{Narrativas up to date}

Menalton Braff procura em suas narrativas abordar problemas atuais como o abuso do álcool e o consumo desenfreado de entorpecentes entre os jovens em Como peixe no aquário e como a compulsão por internet e a violência urbana em Antes da meia-noite. Nesta narrativa, aliás, Braff não resiste a certo didatismo e transmite "boas" mensagens aos seus leitores presumivelmente jovens. Aline confessa o que aprendia em suas conversas com Fabrício (pseudônimo de Gabriel), seu amigo virtual: "Eu estava, de fato, descobrindo que a poesia é um modo diferente de ver o mundo, de ver beleza onde não havia nada" (ibidem, p.55). Convenientemente

seu rico dinheirinho. Pois eu pago tudo. Nem que tenha de trabalhar pelo resto da minha vida, eu pago tudo, ouviu, tia?” (Braff, 2003, p.105). Na ocasião, a mãe de Artur interveio para que ele parasse de falar, mas, depois, confessou: “...não acho que você estivesse errado, não. O que você fez foi exatamente o que eu pensava que você deveria ter feito. Eles calaram a boca” (ibidem, p.106). 
esclarecida por Fabrício, Aline já achava o chat chato: “...e o papo, mãe do céu, não sei como foi que por tanto tempo fez a minha cabeça" (ibidem, p.74-5). Em uma página totalmente vermelha, Aline reflete sobre a sexualidade:

...a ideia do sexo é sempre muito excitante, uma coisa que parece correr por dentro das veias da gente, mas que é preciso saber esperar a hora certa [sic]. Conheço algumas meninas para quem o sexo não é mais mistério. Uma delas engravidou e abandonou a escola. Outra fez um aborto malfeito e quase morreu. Eu, hein!, com tanta pílula e camisinha por aí dando sopa, é ser muito pamonha. (ibidem, p.93)

Como se nota, o narrador-protagonista fica nesses fragmentos reduzido à condição de porta-voz do autor, ansioso por transmitir conselhos úteis e ideias apaziguadoras e edificantes aos seus incautos leitores.

Das quatro obras aqui estudadas, Janela aberta pode ser considerada uma narrativa de caráter histórico, pois a crise da família de Raimundo ocorre no final do período conhecido como "milagre econômico" (1968-1973). Embora alguns dos problemas abordados permaneçam atuais - como o desemprego estrutural, o preconceito contra os trabalhadores de meia-idade e a exploração do proletariado pelo capital industrial -, outros, como a interdição do sexo antes do casamento, perderam relevância.

\section{Janela aberta: primeira narrativa juvenil}

Assim como as três outras narrativas aqui estudadas, Janela aberta, apesar dos graves problemas enfrentados pela família de Raimundo, tem um final feliz, deixando à frente de $\mathrm{Edu}^{6}$ e Laura

6 Edu assemelha-se a Alberto, de Castelos de papel, no início de sua irresistível ascensão profissional e financeira. Ambos estabelecem lutas ásperas com colegas de trabalho e descobrem o sedutor apelo dos bens de consumo. 
um futuro a ser construído. Das quatro narrativas, é a mais elaborada do ponto de vista formal, embora não seja acompanhada de ilustrações ou de extravagâncias tipográficas como as de Antes da meia-noite. Em Janela aberta, representa-se o precoce confronto de jovens com o mundo adulto, o que gera neles um sentimento de desamparo e alimenta suas atitudes de rebeldia, as quais também resultam, em larga medida, de sua imaturidade ou de seu desconhecimento do mundo. Os protagonistas de Antes da meia-noite, A esperança por um fio e Como peixe no aquário são imaturos e/ou rebeldes, mas não chegam ao grau de enfrentamento da autoridade paterna atingido por Laura em Janela aberta. Neste romance, consequentemente, revela-se ainda mais intensamente o choque de gerações entre pais e filhos. Como nas outras narrativas, os problemas resolvem-se em Janela aberta pela ação do amor, que une indissoluvelmente pais e filhos. Com seu caráter histórico, Janela aberta não manifesta tão intensamente a tendência das narrativas de Menalton Braff para a abordagem de problemas atuais. No entanto, ao representar as experiências das personagens fortemente condicionadas pelas circunstâncias históricas e sociais, possibilita um conhecimento mais amplo do mundo e vai muito além da previsível tematização das angústias e conflitos de adolescentes e jovens, da transmissão de boas mensagens e da criação de personagens que favoreçam a identificação projetiva por parte dos presuntivos leitores. Aline, Rita de Cássia e Artur podem ser uma representação fidedigna dos adolescentes atuais, mas Laura e Edu são personagens muito mais vivas e mais convincentes do ponto de vista literário. 


\section{REFERÊNCIAS BIBLIOGRÁFICAS}

A., A. [AZEVEDO, Artur.] Machado de Assis. O Álbum, Rio de Janeiro, n.2, p.9-11, jan.1893.

. Moreira Sampaio. O Álbum, Rio de Janeiro, n.16, p.121-2, abr. 1893.

. Despacho. O Álbum, Rio de Janeiro, n.19, p.151, maio 1893.

. Eduardo Garrido. O Álbum, Rio de Janeiro, n.21, p.161-2, maio 1893.

Fontoura Xavier. O Álbum, Rio de Janeiro, n.35, p.273-4, ago. 1893.

Martins Júnior. O Álbum, Rio de Janeiro, n.50, p.73-4, mar. 1893.

ALBUQUERQUE, J. J. de C. da C. M. e. Canções da decadência. Pelotas: Carlos Pinto, 1889.

. Pecados. Rio de Janeiro: Tipografia da Papelaria Parisiense, 1889. . Páginas de crítica. Rio de Janeiro: Leite Ribeiro \& Maurillo, 1920. . Quando eu era vivo... Memórias: 1867 a 1934. Ed. póstuma e definitiva. Porto Alegre: Livraria do Globo, 1942.

ALMEIDA, J. L. de. Histórias da nossa terra. 18. ed. cor. e aum. Rio de Janeiro: Francisco Alves, 1925.

AMARANTE [pseudônimo de Artur Azevedo]. O missal. O Álbum, Rio de Janeiro, n.12, p.93-4, mar. 1893.

ANDERSON, B. Comunidades imaginadas: reflexões sobre a origem e a difusão do nacionalismo. Trad. de Denise Bottman. São Paulo: Companhia das Letras, 2008. 
ANDRADE, T. de. Saudade. 56.ed. São Paulo: Companhia Editora Nacional, 1966.

ARARIPE JÚNIOR, T. de A. Obra crítica de Araripe Júnior. v.5, 1911 e Anexos. Rio de Janeiro: Ministério da Educação e Cultura, Fundação Casa de Rui Barbosa, 1970.

ASSIS, J. M. Machado de. A nova geração. In: Obra completa. v.3. Nona reimpressão da edição de 1959. Rio de Janeiro: Nova Aguilar, 1997. p.809-36.

. Eça de Queirós: O primo Basílio. In: Obra completa. v.3. Rio de Janeiro: Nova Aguilar, 1997. p.903-13.

Notícia da atual literatura brasileira: instinto de nacionalidade. In: Obra completa. v.3. Nona reimpressão da edição de 1959. Rio de Janeiro: Nova Aguilar, 1997. p.801-9.

AUERBACH, E. Mimesis: a representação da realidade na literatura ocidental. 4.ed. São Paulo: Perspectiva, 1998.

AULETE, J. C. Seleta nacional: curso prático de literatura portuguesa. Segunda parte: Oratória. 2.ed. Lisboa: António Maria Pereira, 1908.

AUGUSTO, P. Vem! O Álbum, Rio de Janeiro, n.15, p.115, abr. 1893.

AZEREDO, M. de. Baiser vengeur. O Álbum, Rio de Janeiro, n.46, p.367, maio 1894.

AZEVEDO, A. O homem. Posfácio de Letícia Malard. Belo Horizonte: Editora da UFMG, 2003.

AZEVEDO, A. Cavaco preliminar. O Álbum, Rio de Janeiro, n.1, p.1, jan.1893.

Cavaco. O Álbum, Rio de Janeiro, n.50, p.393, set. 1894.

O teatro: carta a Coelho Neto. A Notícia, Rio de Janeiro, p.2, rodapé, 17 fev.1898.

Zola. O País, Rio de Janeiro, p.1, 1. col., 6 out. 1902.

B. [Olavo Bilac]. Registro. A Notícia, Rio de Janeiro, p.2, 1. col., 10 jan.1905.

BARRETO, A. de O. Vários estilos: seleta de trabalhos literários de autores modernos e contemporâneos. 2.ed. São Paulo: Weiszflog Irmãos, 1919.

Leituras morais. 18.ed. rev. Rio de Janeiro: Francisco Alves, 1922.

BARRETO, F.; LAET, C. de (ed.). Antologia nacional. 13.ed. Rio de Janeiro: Francisco Alves, 1928.

BARRETO, P. O Simbolismo. Cidade do Rio, Rio de Janeiro, p.2, 6. col., 3 out. 1899.

. Faz treze anos a Cidade do Rio. Cidade do Rio, Rio de Janeiro, p.2, 2. col., 28 set. 1900. 
BASTOS, M. H. C. Amada pátria idolatrada: um estudo da obra Porque me ufano do meu país, de Afonso Celso. Educar, Curitiba, n.20, p.245-60, 2002.

BATAILlE, G. O erotismo. 2.ed. Trad. de Antonio Carlos Viana. Porto Alegre: L\&PM, 1987.

BILAC, O. Aluísio Azevedo. Luís Murat. O Álbum, Rio de Janeiro, n.27, p.210-1, jul. 1893.

. O Álbum, Rio de Janeiro, n.54, p.10-1, jan.1895.

. Crônica. Gazeta de Notícias, Rio de Janeiro, p.1, 1. col., 5 out. 1902.

Últimas conferências e discursos. Rio de Janeiro: Francisco Alves, 1927.

. Poesias infantis. In: Idem. Obra reunida. Org. e int. de Alexei Bueno. Rio de Janeiro: Nova Aguilar, 1996. p.291-344.

.; BONFIM, M. Livro de leitura para o curso complementar das escolas primárias. 53.ed. Rio de Janeiro: Francisco Alves, 1935.

.; BONFIM, M. Através do Brasil: prática da língua portuguesa. Narrativa. Org. de Marisa Lajolo. São Paulo: Companhia das Letras, 2000 .

.; COELHO NETO. Contos pátrios: Educação moral e cívica (para as crianças). Rio de Janeiro: Garnier, 2001.

BORGES, A. C. [barão de Macaúbas]. Terceiro livro de leitura para uso das escolas brasileiras. Nova ed. ref. e melh. Rio de Janeiro: Francisco Alves, s. d.

BRAFF, M. À sombra do cipreste. Ribeirão Preto (SP): Palavra Mágica, 2000.

Que enchente me carrega? Ribeirão Preto (SP): Palavra Mágica, 2000.

. Castelos de papel. Rio de Janeiro: Nova Fronteira, 2002.

A esperança por um fio. Il. de Lúcia Brandão. São Paulo: Ática, 2003.

. Como peixe no aquário. São Paulo: Edições SM, 2004.

Na teia do sol. São Paulo: Planeta do Brasil, 2004.

. Gambito. Il. de Pepe Casals. São Paulo: Edições SM, 2005.

. A coleira no pescoço. Rio de Janeiro: Bertrand Brasil, 2006.

. A muralha de Adriano. Rio de Janeiro: Bertrand Brasil, 2007.

Antes da meia-noite. Il. de Juliana Russo. São Paulo: Ática, 2007.

BROCA, B. Horas de leitura. Rio de Janeiro: Ministério da Educação e Cultura, Instituto Nacional do Livro, 1957. 
Artur de Oliveira: homem curioso. In: DANTAS, L. (Org.). Naturalistas, parnasianos e decadistas. Campinas: Editora da Unicamp, 1991. p.55-7.

BULCÃO, M. Vida infantil. v.2. São Paulo: Carlos Gerke, 1904.

CAIRO, L. R. V.; MOREIRA, M. E. (Org.). Questões de crítica e historiografia literária. Porto Alegre: Nova Prova, 2006.

CALKINS, N. A. Primeiras lições de coisas: Manual de ensino elementar para uso dos pais e professores. Adaptação a partir da 40.ed. por Rui Barbosa. Rio de Janeiro: Imprensa Nacional, 1886.

CAMARGO, M. L. de B. Confissão de Intimidade. In: Atrás dos olhos pardos. São Paulo, 1990. Tese de (Doutoramento) - Faculdade de Filosofia, Letras e Ciências Humanas da Universidade de São Paulo.

CAMPOS, H. de. Diário secreto. 2v. Rio de Janeiro: O Cruzeiro, 1954.

CANDIDO, A. Prefácio. In: LAJOLO, M. Usos e abusos da literatura na escola: Bilac e a literatura escolar na República Velha. Rio de Janeiro: Globo, 1982.

. Literatura e cultura de 1900 a 1945 (panorama para estrangeiros). In: Literatura e sociedade. 7.ed. São Paulo: Companhia Editora Nacional, 1985, p.109-38.

Os primeiros baudelairianos. In: A educação pela noite e outros ensaios. São Paulo: Ática, 1987. p.23-38.

. De cortiço a cortiço. In: $O$ discurso e a cidade. São Paulo: Duas Cidades, 1993. p.123-52.

CARVALHO, F. de. Seleta de autores modernos ou trechos escolhidos de alguns dos principais autores que têm escrito durante o século XIX. 3.ed. ref. Rio de Janeiro: Livraria Clássica de Alves \& Companhia, 1896.

CARVALHO, H. de. O cromo: estudo de temperamentos. Rio de Janeiro: Tipografia de Carlos Gaspar da Silva, 1888.

CARVALHO, M. de. Hortência. Belém: Fundação Cultural do Pará Tancredo Neves; Secretaria de Estado da Cultura, 1989.

CELSO, A. Porque me ufano do meu país. 12.ed. Rio de Janeiro: F. Briguiet \& Companhia, 1943.

CESAR, A. C. Inéditos e dispersos. 2.ed. São Paulo: Brasiliense, 1991. A teus pés. 8.ed. São Paulo: Brasiliense, 1992. Escritos no Rio. São Paulo: Brasiliense; Rio de Janeiro: UFRJ, 1993.

CIDADE do Rio. Cidade do Rio, Rio de Janeiro, p.3, 1. col., 28 set. 1900. Cidade do Rio, Rio de Janeiro, p.1, 1. col., 6 set. 1901.

CINTRA, A. Alma brasileira. 6.ed. São Paulo: Melhoramentos, s. d. 
CLAUDE [pseudônimo de Paulo Barreto]. Crítica literária. Cidade do Rio, Rio de Janeiro, p.1, 5. col., 3 ago. 1899.

. Crítica literária. Cidade do Rio, Rio de Janeiro, p.2, 5. col., 30 ago. 1899.

. Crítica literária. Cidade do Rio, Rio de Janeiro, p.2, 1. col., 4 set. 1899.

. Crítica literária. Cidade do Rio, Rio de Janeiro, p.2, 5. col., 14 out. 1899.

Crítica literária. Cidade do Rio, Rio de Janeiro, p.2, 8. col., 4 nov.1899.

.A comemoração. Cruz e Sousa. Cidade do Rio, Rio de Janeiro, p.2, 5. col., 23 mar. 1900.

A comemoração. Cruz e Sousa. Cidade do Rio, Rio de Janeiro, p.2, 1. col., 24 mar. 1900.

A comemoração. Cruz e Sousa. Cidade do Rio, Rio de Janeiro, p.3, 2. col., 26 mar. 1900.

O salão de 1900. Cidade do Rio, Rio de Janeiro, p.2, 1. col., 1. set. 1900.

O salão de 1900. Cidade do Rio, Rio de Janeiro, 2. col., p.2, 13 set. 1900 .

COELHO, N. N. Dicionário crítico da literatura infantil e juvenil brasileira. 5.ed. rev. e atual. São Paulo: Companhia Editora Nacional, 2006. COELHO NETO, Henrique Maximiliano. A conquista. 3.ed. Porto: Chardron, 1921.

Breviário cívico. 5.ed. Brasília: Academia de Letras de Brasília,1921.

Apólogos: Contos para crianças. 4.ed. Porto: Chardron, 1924.

.; BILAC, Olavo. A Pátria brasileira (para os alunos das escolas primárias). 14.ed. Rio de Janeiro: Francisco Alves, 1918.

COIMBRA, F. Diálogos. A Notícia, Rio de Janeiro, p.2, 2. col., 22 nov.1895.

COSIMO [pseudônimo de Artur Azevedo]. Livros novos. O Álbum, Rio de Janeiro, n.38, p.302-3, set. 1893.

COUTINHO, A.; SOUSA, J. G. de. Enciclopédia de literatura brasileira. 2v. 2.ed. rev., ampl., at. e il. sob a coordenação de Graça Coutinho e Rita Moutinho. São Paulo: Global, Rio de Janeiro: Fundação Biblioteca Nacional, Academia Brasileira de Letras, 2001.

CRULS, G. Aparência do Rio de Janeiro. v.2. Rio de Janeiro: J. Olympio, 1949.

CRUZ E SOUSA. Cidade do Rio, Rio de Janeiro, p.1, 4. col., 19 mar. 1900. 
Cidade do Rio, Rio de Janeiro, p.2, 4. col., 20 mar. 1900.

DANTAS, V. A Nova Poesia Brasileira \& A Poesia. Novos estudos CEBRAP. São Paulo, Centro Brasileiro de Análise e Planejamento, v.16, p.40-53, $12 / 86$.

DIMAS, A. A encruzilhada do fim do século. In: PIZARRO, A. (Org.). América Latina: palavra, literatura e cultura. São Paulo: Memorial; Campinas: Unicamp, 1994. v.2, p.534-74.

Bilac, o jornalista. 3v. São Paulo: Imprensa Oficial; Editora da Universidade de São Paulo; Campinas: Editora da Unicamp, 2006.

DOLORES, C. Lendas brasileiras: coleção de 27 contos para crianças. Il. de Julião Machado. São Paulo: Sá, 2006.

DUQUE-ESTRADA, O. Noções de história do Brasil. 7.ed. Rio de Janeiro: Francisco Alves, 1930.

EMÍlIO Zola. A Notícia, Rio de Janeiro, p.1, 3. col., 30 set. 1902. . Jornal do Brasil, Rio de Janeiro, p.1, 2.-3. col., 30 set. 1902. O Estado de São Paulo, São Paulo, p.1, 1. col., 30 set. 1902. O País, Rio de Janeiro, p.1, 5. col., 30 set. 1902.

ENVIANDO-NOS o soneto... O Álbum, Rio de Janeiro, n.8, p.62, fev.1893.

ESCARPIT, R. Sociologie de la littérature. Paris: Presses Universitaires de France, 1964.

FARIA, J. R. O teatro realista no Brasil: 1855-1865. São Paulo: Editora da Universidade de São Paulo, 1993.

FLEURY, R. S. Série Pátria Brasileira: Leitura IV. 3.ed. São Paulo: Melhoramentos, 1945.

FONTOURA, A. Confronto. O Álbum, Rio de Janeiro, n.19, p.150, maio 1893.

FRAGOSO, A. O Álbum - O último jornal literário de Artur Azevedo. Revista do Livro, Rio de Janeiro, v.12, p.171-6, dez. 1958.

GOES, C. Histórias da terra mineira. Rio de Janeiro: Garnier, 2001.

GOMES, R. C. (Ed.). João do Rio. Rio de Janeiro: Agir, 2005. (Nossos Clássicos).

GRAMSCI, A. Os intelectuais e a organização da cultura. 3.ed. Trad. de Carlos Nelson Coutinho. Rio de Janeiro: Civilização Brasileira, 1979.

GUINSBURG, J; FARIA, J. R; LIMA, M. A. de. Dicionário do teatro brasileiro: temas, formas e conceitos. São Paulo: Perspectiva, Sesc São Paulo, 2006.

HOBSBAWM, E. J. Nações e nacionalismo desde 1780: programa, mito e realidade. Trad. de Maria Célia Paoli e Anna Maria Quirino. Rio de Janeiro: Nova Fronteira, 2011. 
HOLLANDA, H. B. Introdução. In: 26 Poetas hoje. Sel. e int. de H. B. de Hollanda. Rio de Janeiro: Labor do Brasil, 1976.

. Impressões de Viagem: CPC, vanguarda e desbunde: 1960/1970. São Paulo: Brasiliense, 1981.

KREUTZ, L. A educação de imigrantes no Brasil. In: LOPES, E. M. T.; FARIA FILHO, L. M.; VEIGA, C. G. (Org.). 500 anos de educação no Brasil. 3.ed. Belo Horizonte: Autêntica, 2004. p.347-70.

LACERDA, J. M. de. Pequena história do Brasil por perguntas e respostas. Nov. ed. il. rev. e aum. até 1906 por Luís Leopoldo Fernandes Pinheiro. Rio de Janeiro: Francisco Alves, 1911.

LEITE, D. M. O caráter nacional brasileiro: História de uma ideologia. 3.ed. rev., ref. e ampl. São Paulo: Pioneira, 1976.

LOBATO, M. A barca de Gleyre. 14.ed. São Paulo: Brasiliense, 1972.

LÚCIFER. Fui do jardim do Apolo ao jardim do Recreio. A Bruxa, Rio de Janeiro, p.7, 2. col., 7 fev.1896.

LÚCIO, J. O livro de Elza. 3.ano. Em col. com Zilah Frota. 39.ed. Rio de Janeiro: Francisco Alves, 1959.

LUSO, J. Dominicais. Jornal do Comércio, Rio de Janeiro, p.1, rodapé, 5 out. 1902.

MACEDO, J. M. de. Lições de história do Brasil para uso das escolas de instrução primária. Ed. rev. e at. Rio de Janeiro: Garnier, c.1915.

MACHADO, G. M. Uma leitura de 26 Poetas Hoje. Revista de Letras. Assis: Inst. de Letras, História e Psicologia, v.20, p.89-98, 1980.

MAGALHÃES JÚNIOR, R. Artur Azevedo e sua época. 2.ed. il., refundida e aum. São Paulo: Martins, 1955.

A vida turbulenta de José do Patrocínio. Rio de Janeiro: Sabiá, 1969.

MALLET, P. Lar. Rio de Janeiro: Tipografia Central, 1888.

MARQUES, X. Uma família baiana. Bahia [sic]: Imprensa Popular, 1888.

MENCARELLI, F. A. Cena aberta: a absolvição de um bilontra e o teatro de revista de Artur Azevedo. Campinas: Editoria da Unicamp, Centro de Pesquisa em História Social da Cultura, 1999.

MENDES, C. Poema da carne. O Álbum, Rio de Janeiro, n.32, p.252, ago. 1893.

MENDONÇ.A, L. de. V. M. O Álbum, Rio de Janeiro, n.33, p.257-8, ago. 1893.

MÉRIAN, J.-Y. Aluísio Azevedo: vida e obra (1857-1913). O verdadeiro Brasil do século XIX. Rio de Janeiro: Espaço e Tempo, Instituto Nacional do Livro, 1988. 
MERQUIOR, J. G. Capinan e a Nova Lírica. In: A Astúcia da mimese. Rio de Janeiro, J. Olímpio/Conselho Est. de Cultura, 1972.

. Musa Morena Moça: notas sobre a nova poesia brasileira. In: . O fantasma romântico e outros ensaios. Rio de Janeiro, Vozes, 1980.

MIGUEL PEREIRA, L. História da literatura brasileira: prosa de ficção: de 1870 a 1920. Belo Horizonte: Itatiaia; São Paulo: Editora da Universidade de São Paulo, 1988.

NEVES, F. A Academia Brasileira de Letras. Notas e documentos para a sua história (1896-1940). Pref. de Afrânio Peixoto. Rio de Janeiro: Publicações da Academia Brasileira, 1940.

OLIVEIRA, V. C. de. Nossa Pátria: Pequena enciclopédia nacional para uso das escolas brasileiras. 3.ed. Paris: Aillaud, 1908. Trata-se da terceira edição refundida e ampliada de A pátria brasileira.

PASSOS, G. Olavo Bilac. O Álbum, Rio de Janeiro, n.13, p.97-8, mar. 1893.

PASSOS, S. dos [pseudônimo de Menalton Braff]. Janela aberta. São Paulo: Seiva, 1984.

Na força de mulher. São Paulo: Seiva, 1984.

PAZE, E. Encore. O Álbum, Rio de Janeiro, n.49, p.389, jun.1894.

PEIXOTO, A. Minha terra e minha gente. 2.ed. Rio de Janeiro: Francisco Alves; Paris: Aillaud; Lisboa: Bertrand, 1916.

PIMENTEL, F. Requiem. O Álbum, Rio de Janeiro, n.37, p.295, set. 1893. Contos da Carochinha: Livro para crianças. 25.ed. Rio de Janeiro: Quaresma, 1959.

. Histórias da avozinha: Livro para crianças. Nova ed. Rio de Janeiro: Livraria Quaresma, 1959.

Teatrinho infantil: Livro para crianças. Nova ed. Rio de Janeiro: Livraria Quaresma, 1959.

PINTO, A. C. Seleta em prosa e verso dos melhores autores brasileiros e portugueses. 45.ed. Porto Alegre: Selbach, 1937.

POMBO, R. Nossa pátria: Narração dos fatos da história do Brasil, através da sua evolução com muitas gravuras explicativas. 79.ed. São Paulo: Melhoramentos, 1917.

PRADO, D. de A. História concisa do teatro brasileiro (1570-1908). São Paulo: Editora da Universidade de São Paulo, 1999.

REIS, O. de S. Noções de história do Brasil. 5.ed. Rio de Janeiro: Francisco Alves, 1935. 
RIBEIRO, João. História do Brasil: Curso superior. 17.ed. rev. e compl. por Joaquim Ribeiro. Rio de Janeiro: Francisco Alves, 1960.

RIBEIRO, Júlio. A carne. São Paulo: Círculo do Livro, 1991.

ROMERO, S. O alemanismo no sul do Brasil. Publicado originalmente sob forma de opúsculo (Rio de Janeiro: Heitor Ribeiro, 1906). In: Realidades e ilusões no Brasil: Parlamentarismo e presidencialismo e outros ensaios. Sel. e coord. de Hildon Rocha. Petrópolis: Vozes, 1979. p.229-60.

SANTOS, J. dos [pseudônimo de Medeiros e Albuquerque]. Crônica literária. A Notícia, Rio de Janeiro, p.2, rodapé, 11 fev.1898.

SANTOS, J. dos. Crônica literária. A Notícia, Rio de Janeiro, p.2, rodapé, 4 mar. 1898.

. Crônica literária. A Notícia, Rio de Janeiro, p.2, rodapé, 19 mar. 1898.

. Crônica literária. A Notícia, Rio de Janeiro, p.2, rodapé, 13 maio 1898.

Crônica literária. A Notícia, Rio de Janeiro, p.2, rodapé, 17 jun.1898.

. Crônica literária. A Notícia, Rio de Janeiro, p.2, rodapé, 12 ago. 1898. 1898.

Crônica literária. A Notícia, Rio de Janeiro, p.2, rodapé, 9 set.

. Crônica literária. A Notícia, Rio de Janeiro, p.2, rodapé, 29 jan.1900. 1900.

Crônica literária. A Notícia, Rio de Janeiro, p.2, rodapé, 31 mar.

. Crônica literária. A Notícia, Rio de Janeiro, p.2, rodapé, 9 jun.1900. 1900.

Crônica literária. A Notícia, Rio de Janeiro, p.3, alto, 27 ago.

. Crônica literária. A Notícia, Rio de Janeiro, p.2, rodapé, 17 set. 1900.

. Crônica literária. A Notícia, Rio de Janeiro, p.2, alto, 8 out. 1900.

. Crônica literária. A Notícia, Rio de Janeiro, p.3, 1. col., 12 jun.1902.

. Crônica literária. A Notícia, Rio de Janeiro, p.3, rodapé, 1ํo out. 1902.

. Crônica literária. A Notícia, Rio de Janeiro, p.1, rodapé, 9 out. 1902. 
Crônica literária. A Notícia, Rio de Janeiro, p.3, alto, 1ำ jul. 1903. . Crônica literária. A Notícia, Rio de Janeiro, p.3, alto, 5 ago. 1903. . Crônica literária. A Notícia, Rio de Janeiro, p.3, alto, 21 out. 1903. Crônica literária. A Notícia, Rio de Janeiro, p.3, alto, 10 fev.1905. Crônica literária. A Notícia, Rio de Janeiro, p.3, alto, 13 out. 1905.

SETTE, M. Brasil, minha terra! Leituras cívicas. 14.ed. São Paulo: Melhoramentos, 1953.

SEVCENKO, N. A capital irradiante: técnica, ritmos e ritos do Rio. In: NOVAES, F. (Ed.). História da vida privada no Brasil. v.3. São Paulo: Cia. das Letras, 1998. p.513-619.

SILVA, L. História do teatro brasileiro. Rio de Janeiro: Ministério da Educação e Saúde, 1938.

SILVA, O. e. Rabiscos. Emílio Zola. Gazeta de Notícias, Rio de Janeiro, p.2, 3. col., 5 out. 1902.

SIMÕES JUNIOR, A. S. As resenhas de livros simbolistas no vespertino A Notícia (1897-1905). In: Intelectuais e imprensa: aspectos de uma complexa relação. São Paulo: Nankin, 2010, p.139-56.

O jovem Paulo Barreto e os simbolistas. Itinerários. Araraquara: Unesp, v.31, p.161-74, 2010.

Entre Zola e Eça: o Naturalismo brasileiro em seu apogeu. Olho d’Água. v.4, n.1, 2012.

SODRÉ, N. W. A história da imprensa no Brasil. Rio de Janeiro: Civilização Brasileira, 1966.

SOULARY, J. Rêves ambitieux. O Álbum, Rio de Janeiro, n.17, p.129, abr. 1893.

SOUSA, I. de. O missionário. São Paulo: Ática, 1987.

SOUSA, J. G. de. O teatro no Brasil. 2v. Rio de Janeiro: Instituto Nacional do Livro, 1960.

SÜSSEKIND, F. Literatura e vida literária: polêmicas, diários e retratos. Rio de Janeiro, J. Zahar, 1985.

TINHORÃO, J. R. Pequena história da música popular: da modinha à canção de protesto. Petrópolis: Vozes, 1974.

TORRES, A. O problema nacional brasileiro: introdução a um programa de organização nacional. 3.ed. São Paulo: Companhia Editora Nacional; INL/MEC, 1978.

VALENÇA, R. T. Artur Azevedo e a língua falada no teatro. In: AZEVEDO, A. O Tribofe: revista fluminense do ano de 1891. Estabelecimento do texto, notas e estudo linguístico de Rachel Teixeira Valença. 
Rio de Janeiro: Nova Fronteira, Fundação Casa de Rui Barbosa, 1986. p.225-52.

VELHOTE. No nosso tempo... O Alcazar-III. A Notícia, Rio de Janeiro, p.1, 2. col., 7 nov.1896.

VENEZIANO, N. O teatro de revista no Brasil: dramaturgia e convenções. Campinas: Pontes, Editora da Unicamp, 1991.

VERÍSSIMO, J. Emílio Zola. Correio da Manhã, Rio de Janeiro, p.1, 1. col., 3 out. 1902.

VERÍSSIMO, José. A educação nacional. 3.ed. Porto Alegre: Mercado Aberto, 1985.

ZILBERMAN, R.; MAGALHÃES, L. C. Literatura infantil: autoritarismo e emancipação. São Paulo: Ática, 1982.

ZOLA. Cidade do Rio, Rio de Janeiro, p.1, 2. col., 30 set. 1902.

Gazeta de Notícias, Rio de Janeiro, p.1, 1. col., 30 set. 1902.

ZOLA, E. La terre. Paris: Gallimard, 1999. 
SOBRE O LIVRO

Formato: $14 \times 21 \mathrm{~cm}$

Mancha: 23,7 x 42,5 paicas

Tipologia: Horley Old Style 10,5/14

Papel: Off-set $75 \mathrm{~g} / \mathrm{m}^{2}$ (miolo)

Cartão Supremo $250 \mathrm{~g} / \mathrm{m}^{2}$ (capa)

1a edição: 2014

EQUIPE DE REALIZAÇÃO

Coordenação Geral

Marcos Keith Takahashi 
Neste livro estuda-se a múltipla atuação de escritores junto ao rarefeito público disponível no Brasil. No final do século XIX, escreviam-se textos e libretos para o teatro musicado; procurava-se nacionalizar os romances naturalistas de Eça de Queirós e Émile Zola; descobriam-se as sedutoras possibilidades do livro paradidático; experimentados escritores aventuravam-se na imprensa, dirigindo revistas literárias como O Álbum (1893-1895); intelectuais como Medeiros e Albuquerque e Artur Azevedo conquistavam prestígio e influência exercendo a crítica literária e teatral nos jornais. No início do século $\mathrm{XX}$, o poder político já cooptava os escritores mais importantes, e um jovem de boa família como Paulo Barreto (João do Rio) podia escolher as letras e o jornalismo como profissões sérias. Muitas décadas depois, abria-se a um escritor como Menalton Braff a possibilidade de especializar-se na literatura infanto-juvenil.A quem não aceitasse as regras e ritos do sistema então vigente, restava a possibilidade de inventar novas formas de acesso ao público, como procurou fazer a chamada Geração Mimeógrafo.

Alvaro Santos Simões Junior é professor de Literatura Brasileira na Universidade Estadual Paulista "Júlio de Mesquita Fllho" (Unesp), campus de Assis, e pesquisador do CNPq. Publicou A sátira do Parnaso (2007), compilou crônicas de Olavo Bilac na obra Registro (20II) e organizou as coletâneas de ensaios Intelectuais e imprensa (2010) e Formas do romance em lingua portuguesa (20I2). De forma assídua, tem colaborado em periódicos acadêmicos. 